\title{
Effects of Electronic Communication in General Practice
}

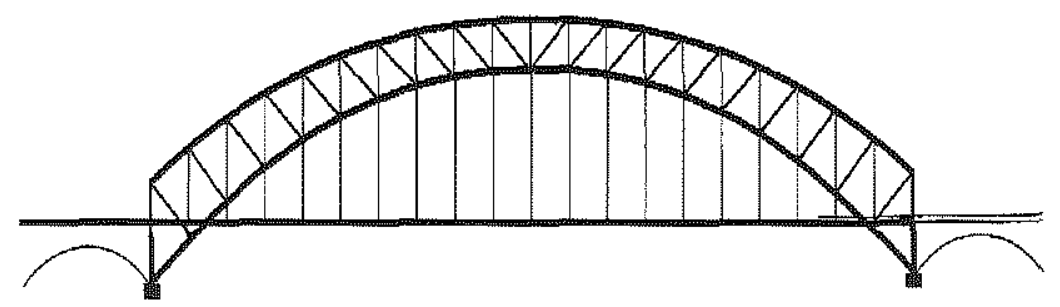

Wouter J. van der Kam 


\section{Acknowledgements}

We acknowledge the financial support of the Isala Clinics, Fonds Doelmatige Farmaceutische Zorg (DFZ) and the EC Fourth Framework Health Telematics Programme (Projects CoCo and Prompt).

Van der Kam, W.J.

Effects of Electronic Communication in General Practice.

Thesis Erasmus University Rotterdam - with summary in Dutch and Frisian

ISBN: 90-9014633-4

Cover photo: G.E.M. Bistervels, Tel./Fax 0529-434243/433301 


\title{
Effects of Electronic Communication in General Practice
}

\section{De effecten van electronische communicatie rondom de huisartsen praktijk}

\author{
proefschrift
}

\begin{abstract}
ter verkrijging van de graad van doctor aan de Erasmus Universiteit Rotterdam op gezag van de Rector Magnificus Prof. dr. ir. J.H. van Bemmel en volgens besluit van het College voor Promoties

de openbare verdediging zal plaatsvinden op woensdag 21 maart om 15.45 uur
\end{abstract}

door

Wouter Jacob van der Kam geboren te Heerenveen 
Promotiecommissie:

Promotoren: $\quad$ Prof. dr. J. van der Lei

Prof. dr. B. Meyboom - de Jong

Overige Leden: $\quad$ Prof. dr. P.J. van der Maas

Prof. dr. J.W. Oosterhuis

Prof. dr. E. Schadé 
„Het is net of je uit allemaal kleine stukjes bestaat en elke behandelaar een klein stukje van je weet.

Het lijkt dan wel of ze niet altijd samenwerken en van elkaar niet weten welk stukje wie heeft onderzocht"

Een patiënt 



\section{CONTENTS}

\section{CHAPTER 1 INTRODUCTION}

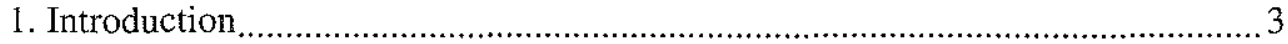

2. Communication in general practice ........................................................ 3

2.1. Electronic communication in general practice ........................................... 3

2.2. The communication between general practitioner and specialist in cases of patients with breast cancer ............................................................... 4

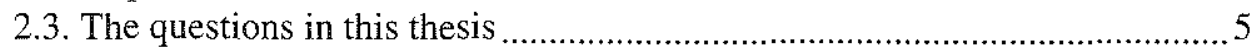

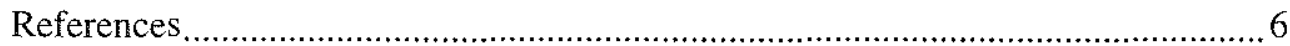

CHAPTER 2 EFFECTS OF ELECTRONIC COMMUNICATION IN GENERAL PRACTICE

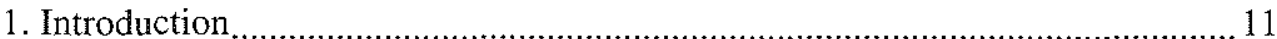

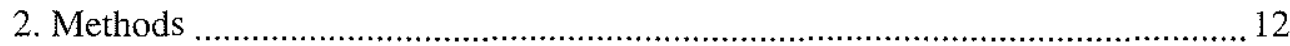

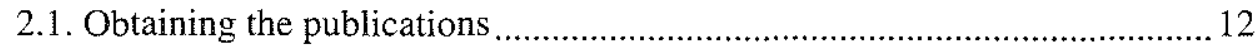

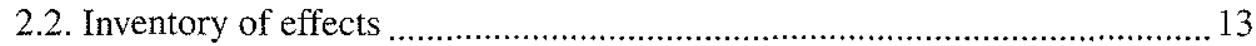

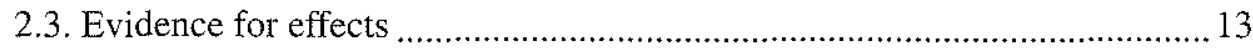

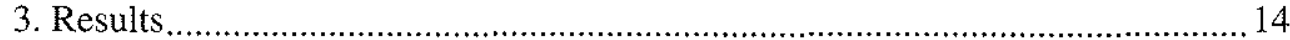

3.1. General characteristics of all publications ............................................ 14

3.2. The nature and evidence of effects ........................................................ 15

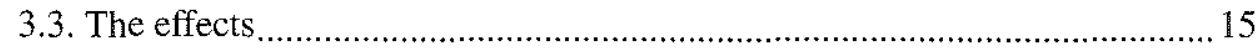

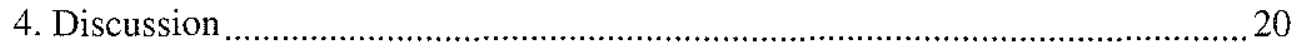

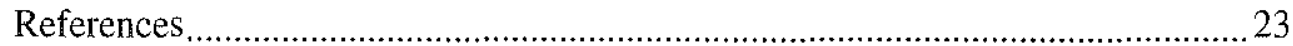

CHAPTER 3 EFFECTS OF ELECTRONIC COMMUNICATION BETWEEN THE GP AND THE PHARMACIST: THE QUALITY OF MEDICATION DATA ON ADMISSION AND AFTER DISCHARGE

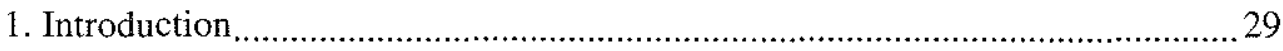

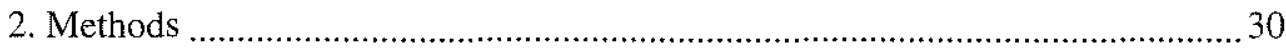

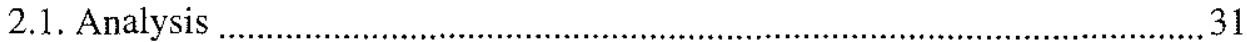

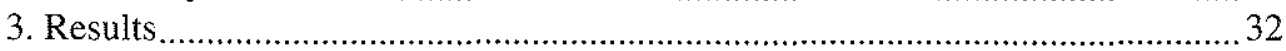

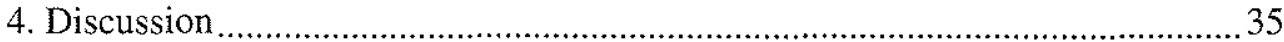

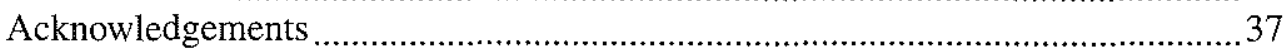

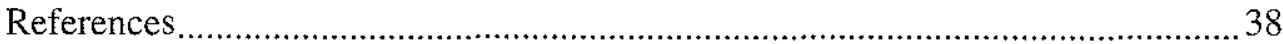


CHAPTER 4 COMMUNICATION BETWEEN PHYSICIANS AND WITH PATIENTS SUFFERING FROM BREAST CANCER

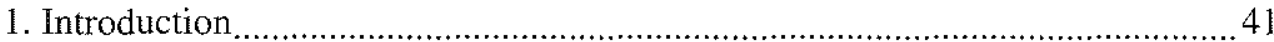

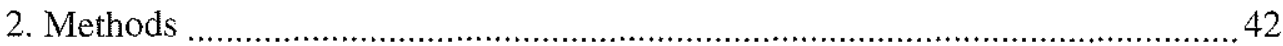

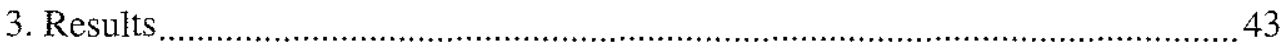

3.1. Speed of communication between GP and specialists ...............................4 44

3.2. Speed of communication between GP and patient ....................................4 44

3.3. Type of communication when referring to surgeon or radiologist ..............45

3.4. Informing the GPs about the definite diagnosis ........................................45

3.5. Problems encountered by GPs in the communication with specialists ...... 46

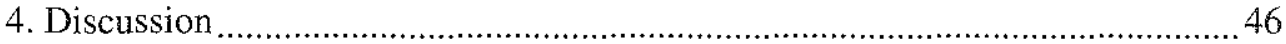

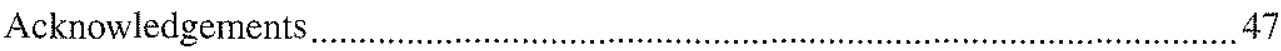

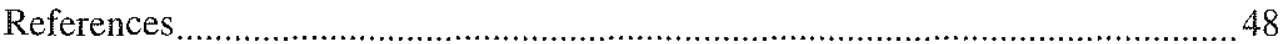

CHAPTER 5 COMMUNICATION AMONG PHYSICIANS WHEN TREATING PATIENTS WITH SUSPECTED BREAST CANCER

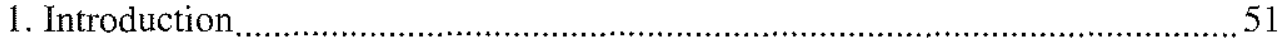

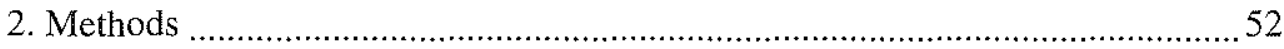

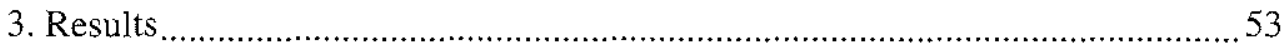

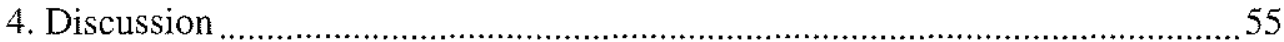

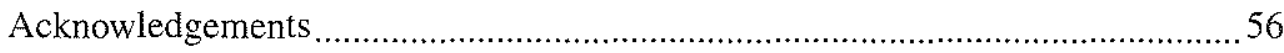

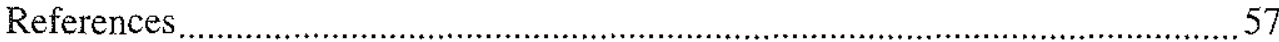

CHAPTER 6 EFFECTS OF ELECTRONIC COMMUNICATION ON THE COMMUNICATION BETWEEN SURGEON AND GENERAL PRACTITIONER FOR PATIENTS SUSPECTED OF BREAST CANCER: A RANDOMISED CLINICAL TRIAL

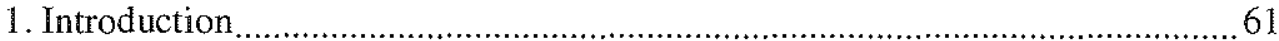

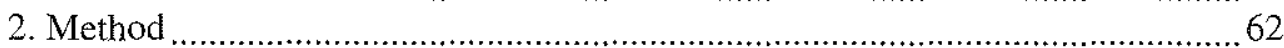

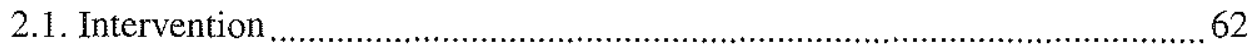

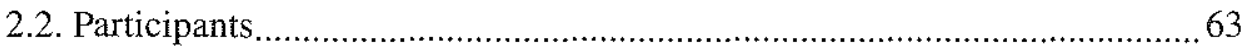

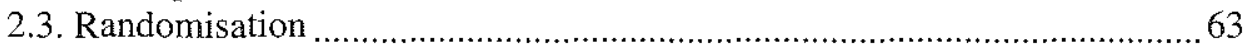

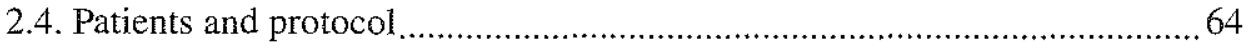

2.5. Outcomes between the general practitioner and the surgeon ....................65

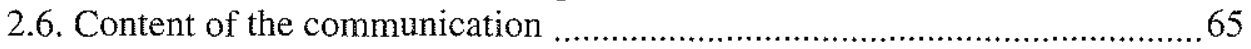

2.7. The speed of communication between the general practitioner and the

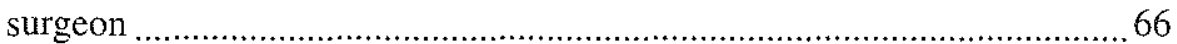

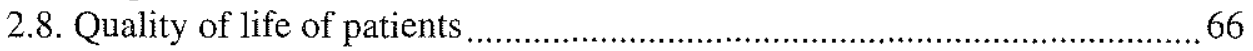

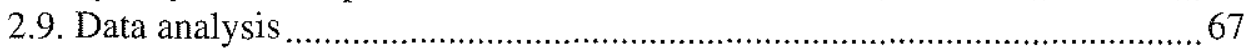

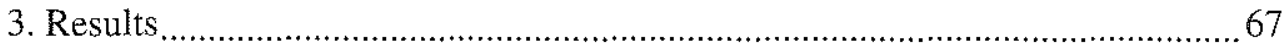

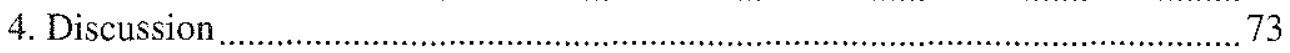

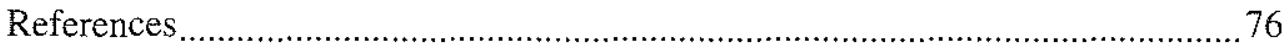


CHAPTER 7 GENERAL DisCUSSION AND RECOMMENDATIONS

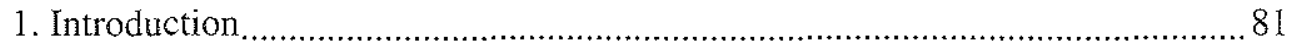

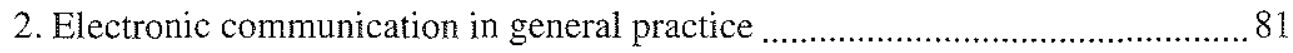

3. The effect of electronic communication on the quality of patient data

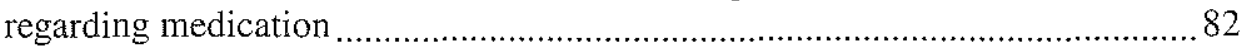

4. The communication between GPs, specialists and patients with breast cancer. 83

5. The effect of electronic communication between GP and surgeon when treating patients with suspected breast cancer ...................................................8 83

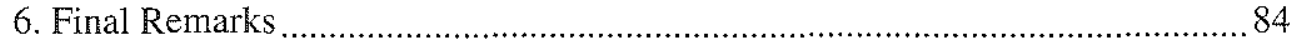

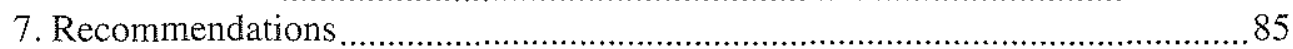

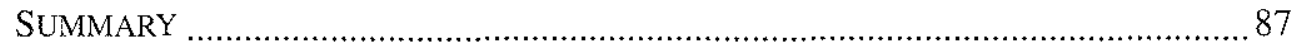

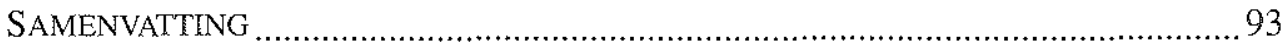

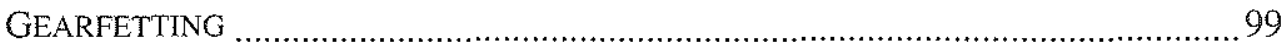

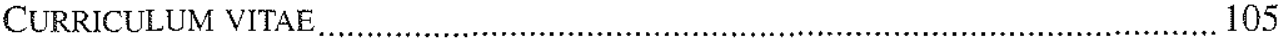

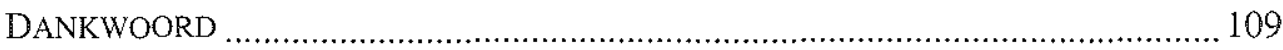

PARTICIPATING DISCIPLINES IN ONE OR MORE STUDIES .................................... 113 

CHAPTER 1

Introduction 



\section{Introduction}

There is a continuous growth in the number of different physicians involved in the treatment of an individual patient. This increase is caused by the growing specialization of physicians in particular fields [1], by the increasing number of physicians that work part time [1], and by transmuralization. With transmuralization is meant the trend to place expensive hospital care partly outside the hospital, whereby general practitioners and specialised nurses fulfill an essential role [1]. Another important cause for the increasing number of physicians is that the average patient becomes much older than before, with the chance of getting more often confronted with different disorders and therefore also with different specialists. The increase in the number of physicians results in a growing need for good communication to guarantee the quality of care [1-6].

\section{Communication in general practice}

In The Netherlands patients usually consult their general practitioner initially; the general practitioner deals with $90 \%$ of all problems of the patient independent of a specialist [7]. If necessary, the general practitioner can write out a prescription with which the patient can get medications at his or her pharmacy. The pharmacist controls the prescription and hands over the medication to the patient. The pharmacist records the prescription in the computer system of the pharmacy and controls the use of the medication and possible interactions with other used drugs.

If necessary, the general practitioner can refer a patient to a specialist. Relevant medical data, the problem and the presentation of the question are put down in a referral letter which is either given to the patient or sent to the specialist. After the examination and/or treatment of the patient, the specialist reports to the general practitioner [8]. The general practitioner can be seen as an 'information manager'. To perform this task well, the general practitioner is also dependent on the information provided by other health-care workers [9]. The traditional paper communication between general practitioners and specialists is, however, too slow [10-14], incomplete [15-20], and contains errors [21]. Bottlenecks in the traditional paper communication between general practitioners and specialists lead to a number of negative results such as time loss, irritation, nonoptimal or incorrect treatment, unnecessary duplication of examinations, and disturbances in the relation between physician and patient [8-21].

\subsection{Electronic communication in general practice}

In the early nineties, the general practitioners started the introduction of electronic medical files for the registration of patient data [22]. Nowadays, the greater part of the Dutch general practitioners has an electronic archive [23,24]. 
The EMD (also know as electronic patient report, EPR) in the general practice plays an important role. Not only all patient data are put down (including diagnoses and medication), but the file is also used for activities such as preventive care (for instance a call for vaccinations), or care control (for instance, a check for interactions and contra-indications).

Also, the general practitioner is increasingly making use of his EMD to communicate electronically with other health-care providers [24]. With the aid of the EMD, the general practitioner can electronically send data to - and receive data from - other information systems, such as hospital laboratory and pharmacies; we call this electronic communication.

The form of electronic communication by which the content is also very much structured, is known as Electronic Data Interchange (EDI). Different authors, however, use different definitions of EDI. Walker defines EDI as "the replacement of paper documents by standard electronic messages conveyed from one computer to another without manual intervention" [25]. This definition of EDI is very broad; electronic mail and information exchange via magnetic media would, according to this definition, fall under EDI. Therefore, Veth proposes as a definition for EDI: "the structured exchange and use of standardised messages between computer systems of different organizations without manual intervention" [26]. The general practitioner in The Netherlands uses mainly EDIFACT messages for EDI. There are message definitions for various purposes, such as laboratory results, admission and discharge messages, prescriptions and referral letters. Through the availability of electronic communication, the general practitioner has new possibilities within reach to exchange data with other care workers. However, about the effects of this new method of communication little is yet known.

\subsection{The communication between general practitioner and specialist in cases of patients with breast cancer}

Breast cancer is the most common malignant disease in women in The Netherlands, with incidence 115.5 cases per 100,000 women [27]. The diagnostic and the treatment of breast cancer require a major and mostly multidisciplinary treatment of surgeon, radiotherapist and internist.

There are several circumstances that give rise to suspicion of breast cancer. Some women feel a small lump in a breast. Other women regularly undergo a periodical, preventive examination within the framework of age, or because their family shows a history of breast cancer. In many cases, the general practitioner is first consulted who, after anamnesis and examination, can decide to refer the patient to a surgeon. The surgeon reports back to the general practitioner after examination and treatment. The surgeon can also refer to other specialists such as radiotherapists and internists.

Breast cancer is a serious disease. Patients with breast cancer undergo important physical and psychological consequences from both the disease as the treatment, such as fear and depression [28-32]. Although the general practitioner referred the 4 
patient to the specialist, the patient can still contact the general practitioner to discuss the various aspects of her illness.

Little is known about the degree in which the patient after referral to and during treatment by the specialist continues to call upon the general practitioner. Neither is known whether in such cases the general practitioner has sufficient information. True enough, it is known that the quality of the communication between general practitioner and specialist does have influence on the care for the patient with cancer $[33,34]$.

\subsection{The questions in this thesis}

The survey in this thesis focussed on the inventory of problems in the communication between general practitioner and specialist in relation to patients with breast cancer and the evaluation of the effects of electronic communication between general practitioner-surgeon and general practitioner-pharmacist.

The study poses the following questions:

1. What is the effect of electronic communication in general practice, as described in the peer-reviewed literature? (Chapter 2)

2. What is the effect of electronic communication between the general practitioner and the pharmacist on the information provided by patients, general practitioner, and pharmacist give on the medication used by the patient on the first day of the admission and 10 days after discharge? (Chapter 3 )

3. What is the speed and the type of communication between general practitioners, specialists (radiologist and surgeons) and patients with breast cancer in the period starting from the first referral by the general practitioner to the specialist, to receipt by the general practitioner of the final diagnosis (based on the pathological report, including the examination of the axillary lymph nodes)? (Chapters 4 and 5)

4. What are the bottlenecks and problems that general practitioners encounter in the communication with specialists in relation to patients with breast cancer? (Chapters 4 and 5)

5. What is the effect of electronic communication between general practitioner and surgeons on the implementation of guidelines in relation to communication during the treatment of patients suspected of breast cancer in the diagnostic phase? (Chapter 6)

The conclusions of the thesis will be discussed in Chapter 7, which also contains recommendations, will be given for the future. 


\section{References}

1. Branger PJ. Clinicians at work: Sharing Care in the Information Age. Yearbook of Medical Informatics 1997:83-91.

2. Branger PJ, van der Wouden JC, Schudel BR, Verboog E, Duisterhout JS, van der Lei $\mathrm{J}$, et al. Electronic communication between providers of primary and secondary care [see comments]. Br Med J 1992;305(6861):1068-1070.

3. Branger PJ, Duisterhout JS. Communication in Health Care. Methods Inf Med 1995;34:244-252.

4. Hasman A, Ament A, Arnou PC, van Kesteren ACA. Inter-institutional information exchange in healthcare. Int $J$ Biomed Comput 1992;31:5-16.

5. Van der Wouden JC, Docter HJ. Samenwerking tussen huisarts en specialist bij patienten met kanker (Collaboration between GP and specialist in patients with cancer, in Dutch). Huisarts Wet 1989;32:51-55.

6. Schiff GD, Rucker TD. Computerized Prescribing. Building the electronic infrastructure for better medication usage. JAMA 1998;279(13):1024-1029.

7. Lamberts H. In het Huis van de Huisarts. tweede druk ed. Lelystad: Meditekst, 1994.

8. Westerman RF, Hull FM, Bezemer PD, Gort G. A study of communication between general practitioners and specialists. Br J Gen Pract 1990;40:445-449.

9. Smith R. What clinical information do doctors need? Br Med J 1996;313:1062-1068.

10. Penney TM. Delayed communication between hospitals and general practitioners: where does the problem lie? Br Med J 1988;297:28-29.

11. Branger PJ, van der Wouden JC, Duisterhout JS, van der Lei J. Problems in communication between general practitioners and internal medicine consultants. Med Inform 1995;20:45-51.

12. Hampson JP, Roberts RI, Morgan DA. Shared care: a review of the literature. Fam Pract 1996;13:264-279.

13. Mageean RJ. Study of discharge communications from hospital. $\mathrm{Br}$ Med J 1986;293:1283-1285.

14. Williams EI, Fitton F. General practitioner response to elderly patients discharged from hospital. Br Med J 1990;300:159-161.

15. Grundmeijer H. General practitioner and specialist: why do they communicate so badly? Eur J Gen Pract 1996;2:53-54.

16. Bado W, Williams CJ. Usefulness of letters from hospitals to general practitioners. $\mathrm{Br}$ Med J 1984;288:1813-1814.

17. Clinger NJ, Hunter TB, Hillman BJ. Radiology reporting: attitudes of referring physicians. Radiology 1988;169:376-381.

18. Jacobs LGH, Pringle MA. Referral letters and replies from orthopaedic departments: opportunities missed. Br Med J 1990;301:470-473.

19. Moorman PW, Siersema PD, van Ginneken AM, van Blankenstein M. Are referring physicians satisfied with endoscopy reports? Z Gastroenterol 1994;32:623-625.

20. Tulloch AJ, Fowler GH, McMullan JJ, Spence JM. Hospital discharge reports: content and design. Br Med J 1975;4:443-446.

21. Khoury M, Burnett L, Nackay MA. Error rates in Australian chemical pathology laboratories. Med J Aust 1996;165:128-130. 
22. Van der Lei J, Duisterhout JS, Westerhof HP, van der Does E, Cromme PVM, Boon WM, et al. The introduction of computer-based patient records in The Netherlands. Ann Intern Med 1993;119:1036 1041.

23. Althuis Tj. NUT III rapport. Verslag van enquête onder huisartsen naar praktijkautomatisering (1997): Utrecht NHG, 1999.

24. Van der Lei J. The general practitioner and their primary care information systems. Eprimp proceeding. Rotterdam: Department of Medical Informatics Erasmus University Rotterdam, 1998:38-40.

25. Walker RJ. First steps in EDI: Proceedings of COMPAT 189. Munich: Blenheim Online, 1989.

26. Veth AFL. Woekeren in overvloed. Over de toepassing van EDI en Telematica. Eindhoven: Technisch Universiteit Eindhoven, 1993.

27. Visser O, Coebergh JWW, Schouten LJ, van Dijck JAAM, editors. Incidence of Cancer in The Netherlands 1996. Utrecht: Association of Comprehensive Cancer Centres, 2000.

28. Maunsell E, Brisson J, Deschênes L. Psychological distress after initial treatment of breast cancer. Cancer 1992;70:120-125.

29. Hughes J. Emotional reactions to the diagnosis and treatment of early breast cancer. J Psychsom Res 1982;26:277-283.

30. Morris T. Psychosocial aspects of breast cancer. Eur J Cancer Clin Oncol 1983;19:1725-1733.

31. Battersby C. Psychological implementations of mastectomy. Aust NZ J Surg 1981;51:300-303.

32. Sinsheimer LM, Holland JC. Psychological issues in breast cancer. Semin Oncol 1987; 14:75-82.

33. Cuisinier MCJ, van Eijk JT, Jonkers R, Dokkeru J. Psychosocial care and education of the cancer patient. Strengthening the physicians role. Pat Educ Couns 1986;8:5-16.

34. Wood ML. Communication between cancer specialists and family doctors. Can Fam Physician 1993;39:49-57. 



\section{CHAPTER 2}

\section{Effects of electronic communication in general practice}

Published in: International Journal of Medical Informatics 2000;60:59-70

W.J. van der $\mathrm{Kam}^{1.2}$, P.W. Moorman ${ }^{2}$, M.J. Koppejan-Mulder ${ }^{3}$

'Isala Clinics, Zwolle, The Netherlands

${ }^{2}$ Dept. of Medical Informatics, Faculty of Medicine and Health Sciences, Erasmus University, Rotterdam, The Netherlands

${ }^{3}$ Dept. of General Practice, University of Groningen, Groningen, The Netherlands 



\section{Abstract}

Objective: To obtain insight into the effects of electronic communication on GPs by studying those publications in literature describing the effects of structured electronic clinical communication in general practice.

Methods: We retrieved all publications in the English language indexed in MEDLINE under the MESH term 'Computer Communication Networks' and having either 'family practice' or 'primary health care' as MESH term, or 'GP' or 'GPs' as text word.

Results: A total of 176 publications were retrieved of which 30 publications met the criteria. In 28 of these 30 publications potential effects were described; 1 described claimed effects, 3 described demonstrated effects with subjective data and 5 described demonstrated effects with objective data. The studies documented, furthermore, effects on the speed of communication, the content of information and records, a change of processes involved in the communication, quality of care, costs, workload of physicians, appreciation of physicians, confidentiality, and adherence.

Conclusions: We conclude that only a few studies evaluated electronic communication versus paper communication. Of these studies, only a few report improvement. Our final conclusion is that, so far, literature has not shown that the positive effects can be explained by electronic communication as such.

Keywords: Electronic communication; Computer communication networks; General practitioner, GP; Family practice; Primary health care.

\section{Introduction}

In The Netherlands, most citizens are enrolled in the practice of a General Practitioner (GP). When seeking advice or treatment, the patient usually contacts his or her GP, who acts as a gatekeeper to the health-care system. The GP may refer the patient to other specialists if necessary. The specialist reports back to the GP after diagnosis and/or treatment of the patient. Optimal diagnosis and treatment of the patient requires adequate communication between the GP and specialists involved. The continuity of care depends largely on the quality and frequency of communication between the involved physicians and a clear definition of their findings $[1,2]$. In the continuity of care, the general practitioner (GP) can be seen as the 'information manager'. To do this task well the GP is dependent on the information provided by other members of the health-care system, e.g., specialists.

However, a large number of studies have demonstrated that traditional paper-based communication between GPs and specialists about co-treated patients is prone to be: 
too slow: $\quad$ Studies have shown that 10 to $50 \%$ of discharge letters arrive too late [1,3-6]. A study in Spain even showed that in $78 \%$ of the referrals, the GP did not receive a discharge letter at all [7].

incomplete: Studies have shown that where panels rated letters, 1 in 5 were rated as inadequate, 1 in 3 were confusing, and only $50 \%$ were fully satisfactory [8-10].

inefficient: Most reports are created with computers, printed, then sent via paper mail, and again re-entered into a computer. The inefficiency hereof is obvious.

erroneous: Transcription of data has led to typing errors in a large percentage of cases [11].

The above bottlenecks in the paper-based communication between GPs and specialists can have a range of side-effects. Examples include [3]: unnecessary waste of time and irritation trying to obtain missing information or simply in processing the letter, sub-optimal or even incorrect treatment, doubling of diagnostic tests, feelings of insecurity, anxiety or fear in the patient when the patient does not perceive the health-care system as a whole, and disturbances in patient-doctor relation. New technologies are emerging, and also in health care this resulted in operational information technology systems to document medical data in primary and secondary care. Such systems offer the potential for replacing traditional, paper-based communications by a more direct means of information exchange, namely from computer to computer. In this paper we will call the latter 'electronic communication'. Although it is generally assumed that electronic communication has benefits, we started wondering as to what these benefits are, and how much evidence for such assumptions there is. Furthermore, we also asked ourselves what the negative effects of electronic communication are. Since we did not find any reviews in literature on this topic, we decided to perform such a review, taking the GP as central stakeholder.

In this paper we studied the effect of electronic communication in general practice as described in peer-reviewed, relevant literature.

\section{Methods}

\subsection{Obtaining the publications}

Electronic communication, however, is not a MESH term. We therefore retrieved on August 19th 1999 all English publications indexed in MEDLINE under the MESH term 'Computer Communication Networks' and having either 'family practice' or 'primary health care' as MESH term, or 'GP' or 'GPs' as text word. All retrieved publications were then read and checked independently by the authors to determine whether the publication fulfilled the following criteria:

1. The publication had to describe electronically communicated clinical information to or from the GP. We defined clinical information as 
information used by the receiver on behalf of an individual patient. Thus, for example, a publication describing the use of the internet by the GP to consult protocols did not meet this criterion, whereas a publication describing electronically communicated laboratory test results to a GP did.

2. The publication had to describe at least one effect of electronic communication. To enable a thorough overview of all possible effects, we were lenient with respect to this criterion. A publication was included when it mentioned that the described project 'may lead to a reduction in costs'. Project descriptions that did not mention motivations for performing the project did not meet the criterion.

To ensure completeness of the study, we then checked all references of the included publications. A publication in the references was added to our list if it was not already on the list, but did meet our criteria 1 and 2 .

\subsection{Inventory of effects}

After having established the list of publications we then created a list containing all described effects. For all described effects, we then determined in which original publication an effect was described, and we assigned only the original publication to an effect. For all described effects, we determined also whether an effect was described in preliminary reports of other publications, and we included the effect of a preliminary report only when the effect was not discussed in the final publication.

To provide more overview we categorised all effects in 9 groups and we described the relations between these groups as mentioned in the original publications. For example, the speed of communication leads to (the effect) improved quality of care.

\subsection{Evidence for effects}

To resolve to what degree an effect had been proven in the reviewed literature, we then categorised each effect, as described in its original publication, into one of three classes:

Class 1: Potential effect. An effect was placed in this class when it was described as an expectation without evidence. Typical Class 1 effects were discussed in the introduction of a publication to provide motivation for a project, or described in the discussion as work to be done. An example is the statement that "electronic communication is needed to facilitate the timely, effective and efficient delivery of health care and services to patients".

Class 2: Claimed effect. An effect was placed in this class when it was described as if it had been proven, but the publication contained no evidence, no further data, or no background to verify the (basis of the) statement. For example the statement that "the specialists did not have problems" is being made without mentioning the number of specialists consulted, or 
method used to justify this statement. Effects based on estimates without clear basis were also placed in this class.

Class 3: Demonstrated effect. An effect was placed in this class when the publication provided evidence for the effect. The evidence was either based on subjective or objective data. In the section Results we will distinguish between these two types of data. In the publications, subjective data were obtained by asking opinions or estimates from users through interviews or questionnaires on topics such as appreciation and workload. An example is the statement that "most of the GPs appreciated the new way of communication" based on the fact that 47 GPs scored their appreciation are electronic messages by a 5 point scale ranging from 'much better' to 'much worse'. Effects based on objective data typically compared before and after intervention measurements. It should be realised that for some effects, it is impossible to provide objective data, for example usefulness. On the other hand, evidence of some effects was based on both subjective and objective data: in some studies the speed of communications was measured, in other studies the opinion of the GPs on the speed of communications was determined.

Finally, we made a distinction between effects which the authors considered to be improvements, or beneficial (positive effects) and those effects considered to be disadvantageous (negative effects).

\section{Results}

In total 176 publications were retrieved from MEDLINE, of which 26 complied with all criteria. From the references in these 26 publications, we added another 5 publications that also met the criteria. One publication [12] was excluded because it was both indexed in a conference proceeding (MEDINFO) and in a special issue of a journal dedicated to that conference [13].

\subsection{General characteristics of all publications}

The 30 publications [13-42] originated from seven different countries, namely: The Netherlands 9, the United States 10, United Kingdom 4, France 3, Italy 2, Australia 1 and Finland 1 . Seventeen of the 30 publications dealt with electronically communicated information in general, that is without mentioning a specific type of information. The most often described type of communicated information in the remaining 13 publications were: laboratory reports containing the results of tests (5 publications), notifications of admission and discharge (4 publications), reports from hospital specialists, such as discharge letters and outpatient visit reports ( 3 publications), and the use of electronic communication as consultation, thus as replacement of the traditional referral and consultation (4 publications). Other communications included radiology reports and prescriptions 
(twice), and laboratory test ordering (once). Most publications focussed on more than one type of clinical information exchange.

\subsection{The nature and evidence of effects}

In the 30 publications, a wide variety of effects was discussed. To provide more overview we categorised all effects in 9 groups. Table 1 lists the identified groups of effects of electronic communication, the original publication, the positive or negative nature and the class of evidence as described in that publication. Of the 30 publications, 28 described potential effects (Class 1) of electronic communication [14-27,29-42], of which 1 also described claimed effects (Class 2) [26]. In 3 publications demonstrated effects (Class 3 ) with subjective data $[17,19,28]$ were described, and in 5 publications effects demonstrated with objective data $[13,14,19,20,26]$ were described. Of the 30 publications, 25 described only positive effects. In 4 publications negative effects were also addressed and 1 publication described only negative effects.

\subsection{The effects}

We categorised all effects in 9 groups. Following, we will more extensively describe each group of effects. We will outline the nature and the evidence of effects as discussed in the original publications; and, when applicable, demonstrated effects will be made explicit. As effects do not stand by themselves but can to some degree influence other effects, such relationships between groups of effects, as mentioned in the publications, will also be described. To illustrate these relations we included Figure 1.

The effects described in the publications consisted of effects relating to:

\subsubsection{Speed of communication}

In 8 of the 30 publications it was stated that, compared to paper based communication, electronic communication is faster $[14,19,20,26,31,33,39,40]$.

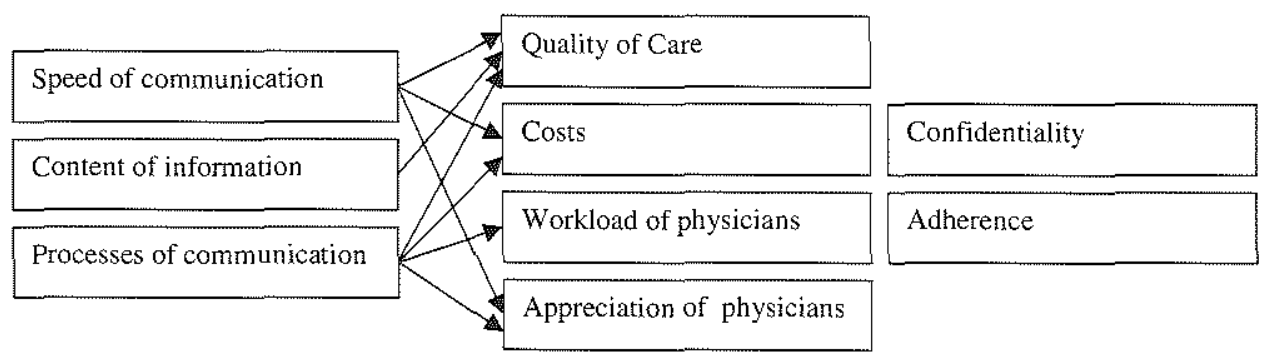

Figure 1. The relations between effects of electronic communication of clinical information with GPs as described in 30 publications. 
Table 1

The effects of electronic communication of clinical information with the GPs, their positive or negative nature, and their class of evidence.

Publications (n 30)

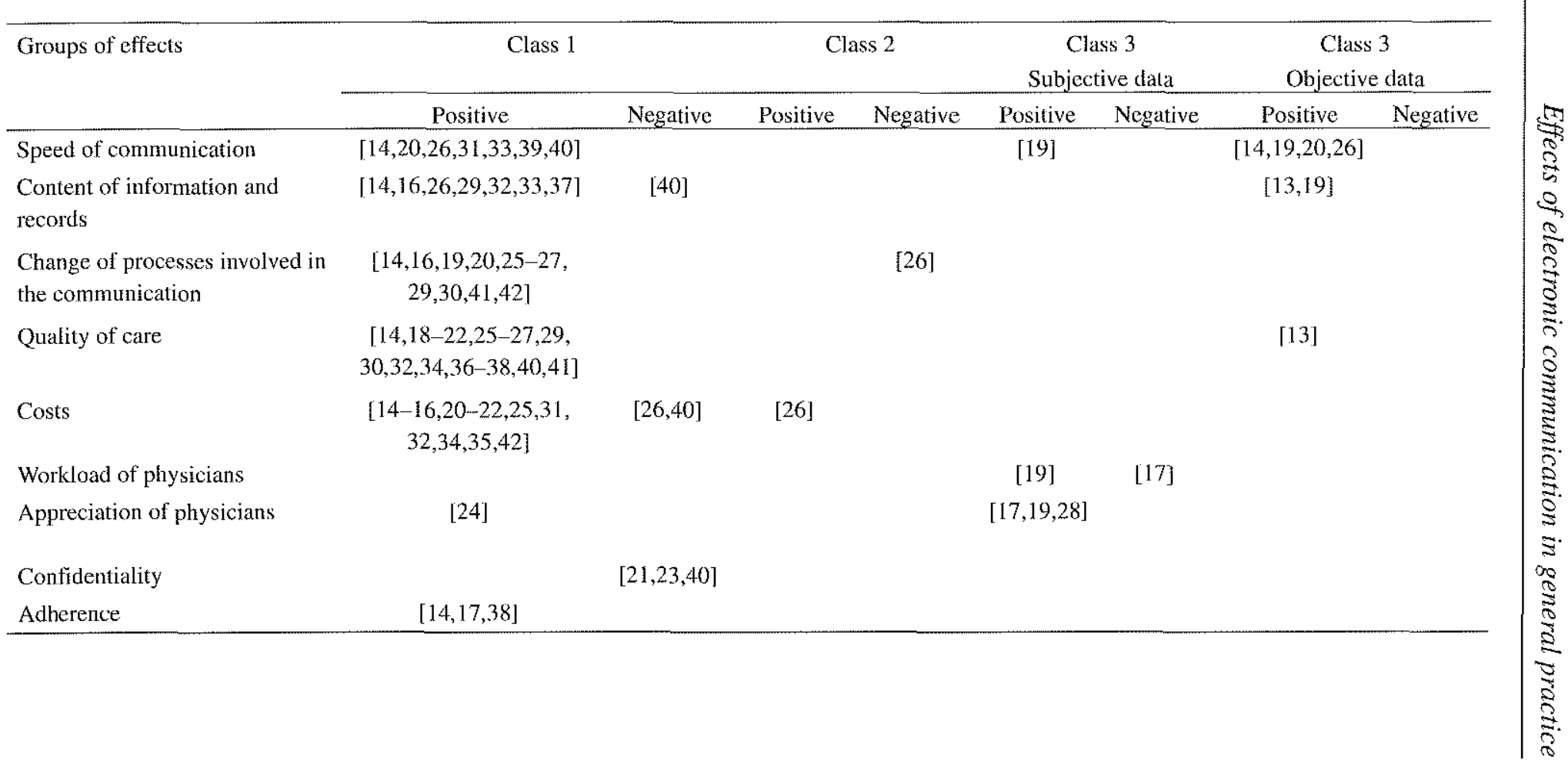


In 2 of the 30 publications it was stated that electronic communication results in an increased frequency of communication $[13,26]$.

Class 3 or demonstrated effects were described in 3 publications [13,19,26]. An average time gain of 1.5-3 days was observed. Time gain will be higher when changes in mail handling have been realised both in the hospital and in the GP practice [26]. Furthermore, GPs receiving electronic messages from the specialist received more messages per year than their paper-based colleagues (1.6 vs. 0.5 messages per patient per year) [13]. It was reasoned that these time gains lead to improved decision making and, therefore, to a higher quality of care (see 3.3.4.) $[14,26]$, a decrease in costs (see 3.3.5.) $[14,26]$ and to more user satisfaction (see 3.3.7.) [19].

\subsubsection{Content of information and records}

In 10 of the 30 publications, it was stated that, compared to paper-based communication, electronic communication results in:

1. A higher quality of the communicated data (due to a reduction of transcription and typing errors) $[14,16,19,26,32,37]$, and

2. More complete information about the care of patients $[13,19,29,32,33]$ as a result from an increased frequency of communication [13].

As a negative effect Regan [40] mentions the danger that decisions will no longer be based on needs for effective care, but rather are taken on basis of technological feasibility. Furthermore, a threat of information overload exists $[13,40]$.

Class 3 or demonstrated effects were described in 2 publications [13,19]. A higher quality of data was found by Branger: manually-entered test results contained errors in $0.5 \%$ of the cases, whereas in those entered electronically no errors were found [19]. In the same publication it was suggested that GPs stored more test results in their medical records when these were communicated electronically: an average increase of 9\% [19]. This finding was confirmed in a study on electronic communication between a specialist and GPs about co-treated diabetic patients [13]. A significant increase in test results dealing with diabetes parameters was found after the intervention. In the publications it was reasoned that higher availability of data and more accurate communication lead to better decisions and better care (see 3.3.4.) $[14,33]$.

\subsubsection{Change of processes involved in the communication}

In 11 of the 30 publications, it was stated that, compared to paper-based communication, electronic communication results in a change of processes, namely in the way messages are created and handled upon receipt. Examples of process changes were:

1. More direct communication between GP and hospital, which makes it easier for the GP to consult specialists about complicated medical problems $[14,29]$. 
2. Integration of messages, e.g., test results can automatically go into the computer-based patient record $[19,26]$. Physicians no longer need to collect data from various forms [26] or to duplicate test results [16]. Integration of messages enables automatic handling of data [20], reduces errors in data processing $[20,27]$ and reduces the time necessary to search data [27].

3. Reduction of telephone calls $[14,16]$ as a result of faster and more frequent communication.

Class 2 or claimed effects were described by Hasman: He concludes that for optimal use of gains from electronic communication, work patterns in hospitals and by GPs will need to be coordinated [26].

Direct communication, integration of test results and reduction of telephone calls will lead to time gains for GPs, hospitals and laboratories [14,26,27]. Furthermore, it ensures shared care: coordination and continuity of care to patients by different health-care professionals $[25,30,41,42]$.

\subsubsection{Quality of care}

In 19 of the 30 publications, it was stated that, compared to paper-based communication, electronic communication improves the quality of care $[3,13$, $14,18,19,21,22,25-27,29,30,32,34,36-38,40,41]$. This is not a direct effect, but originates from faster communication (see under 3.3.1.) [27], higher quality of data (see under 3.3.2.1.) $[14,16,19,26,32,37]$, more complete information (see under 3.3.2.2.) $[13,19,29,32,33]$ and more direct communication (see under 3.3.3.1.) [14,29,36].

A Class 3 or demonstrated effect was described by Branger [13]: diabetic patients about whom the GP had communicated electronically showed a significant decrease in $\mathrm{HbA} 1 \mathrm{C}$ levels. However, the control group also showed a decrease, but not significantly.

\subsubsection{Costs}

In 14 of the 30 publications, it was stated that, compared to paper-based communication, electronic communication results in cost savings [14-16,20$22,25,31,32,34,35,42]$. Ament et al. estimate that cost savings for GPs are between $\$ 500-\$ 750$ per year, and between $\$ 5,000-\$ 54,500$ for laboratories [14].

Cost savings derive from faster communication, e.g., specimen need to be stored during a shorter period (see under 3.3.1.) $[14,26]$, more direct communication (more rational use of diagnostic tests and more rational referrals) $[14,16,21,22,26,31,35]$; reduction of telephone calls $[14,16]$ and savings in mail handling [14,26], stamps [14], paper [14,20] and space for records [32].

Regan, however, suggests that costs for implementing new technologies may outweigh any gains in efficiency, and that gains could be achieved more cheaply by better use of paper records [40]. 
Class 2 or claimed effects were described by Hasman [26]. He concludes that GPs do not gain financial benefits from the use of EDI, and that the costs of electronic data interchange were at the same level as the costs of the traditional system for hospitals.

\subsubsection{Workload of physicians}

In 2 of the 30 publications, it was stated that the workload of physicians is influenced by electronic communication [17,19]. Class 3 or demonstrated effects were described in both publications [17,19]. Of 27 GPs. Ten reported a decrease in workload when using electronic reports for laboratory reports [19]. On the other hand, eight of 24 consultants reported an increased workload when using an Email Consult Service for faculty family physicians [17]. In both publications the change in the workload of physicians was not defined.

\subsubsection{Appreciation of physicians}

In 4 of the 30 publications, it was stated that the appreciation of physicians is influenced by electronic communication [17,19,24,28]. Franken et al. [24] report on an increasing confidence in diagnosis by family practitioners through teleradiology consultation on the family practitioners level .

Class 3 or demonstrated effects were described in three publications $[17,19,28]$. Of the 24 consultants, 20 enjoyed being involved in the use of an E-mail Consult Service for faculty family physicians [17]. Of the 27 GPs, 15 reported that use of admission-discharge reports had provided more accurate knowledge on the care given to individual patients [19]. GPs (45) scoring their appreciation of electronic messages by a 5 point scale ranging from 'much better' to 'much worse' scored an average $1.5-1.8$ for speed, $2.5-2.7$ for reliability, 2.5 for clarity and $1.5-1.7$ for efficiency [28].

\subsubsection{Confidentiality}

In 3 of the 30 publications, it was stated that confidentiality is influenced by electronic communication $[21,23,40]$.

Electronic communication results in faster, direct communication and accessible information for a greater number of health-care professionals, and it implies that special attention must be given to ensure confidentiality, security and privacy of the patient.

\subsubsection{Adherence}

In 3 of the 30 publications, it was stated that the adherence of GPs is influenced by electronic communication [14,17,38]: through the various advantages that 
electronic communication provides, GPs are more likely to make use of hospitals offering such a service. Electronic communication can thus be a marketing instrument for the adherence of GPs.

\section{Discussion}

In the last decades, the complexity and volume of medical knowledge and data increased. This development led to an increased specialization of the health-care professional and an increased number of health-care professionals involved in the care for a given patient. As the number of professionals involved in the care of individual patient increases, the need to ensure good communication also increases $[4,10,43]$. In a number of countries, the GP acts as a gatekeeper in the health-care system. One of the tasks of the gatekeeper is to coordinate the delivery of health care. For these GPs, communication with other health-care providers is of paramount importance. A number of studies, however, report that current paperbased communication is far from being adequate $[1,4,6,44]$. The rapid development of information technology, on the other hand, has created new methods for communication. Investigators have started to study the potential of electronic communication as a means to address the shortcoming of paper-based communication [13-42]. The objective of this paper was to review, from the perspective of a GP, the currently available literature regarding the effects of electronic communication.

Our MEDLINE search resulted in 30 publications that met our eligibility criteria. In these 30 publications, a wide range of effects is described. We categorised the effects mentioned in these publications in 9 groups: speed of communication, content of communication, processes of communication, quality of care, costs, workload of physicians, appreciation of physicians, confidentiality and adherence. These categories are, however, somewhat arbitrary and should be viewed as a first attempt to come to a more general framework. A widely accepted general framework of effects is still lacking. Furthermore, we want to emphasize that our categorization of effects is not all-inclusive; we limit ourselves to the effects mentioned in the publications yielded by our MEDLINE search.

For each effect mentioned in a publication, we categorised the evidence provided by that publication as one of potential effect, claimed effect and demonstrated effect. The category demonstrated effect was further subdivided into demonstrated effect by subjective data and demonstrated effect by objective data. Only 7 publications of the 30 publications described demonstrated effects $[13,14,17$, $19,20,26,28]$. Of the 7 publications with demonstrated effects, 5 presented demonstrated effects with objective data $[13,14,19,20,26]$; the effects documented in these 5 publications were limited to two categories: 'Speed of communication' and 'Content of information and records'. The importance of electronic communication to achieve these effects, however, remains unclear. For example, using the telephone more often instead of writing paper notes could also increase 
the speed of communication. In addition, speed of communication in and of itself is not always desirable; in primary care, for example, some delay may be beneficial in self-limiting diseases.

The ultimate aim of improving communication among health-care professionals is to improve the quality of care. In 18 publications, it was stated that electronic communication improves the quality of care as a potential result from faster communication, more complete data and a higher quality of data $[3,14,18,19$, $21,22,25-27,29,30,32,34,36-38,40,41]$. However, these studies demonstrated no objective data for an improvement in the quality of care. The only paper that actually reports an improved outcome is the paper of Branger who documents a slight improvement in the $\mathrm{HbA1C}$-levels of diabetic patients [13]. We are forced to conclude that literature provides a disappointingly small number of studies that demonstrate the improvement of the quality of care by means of electronic communication.

We are puzzled by the discrepancy between the scarcity of documented impact on the quality of care and the abundance of electronic communication projects in conference proceedings $[45,46]$, in reports of funding agents [47] and on the internet world wide web $[40,48]$. A possible explanation for this discrepancy could be that many studies dealing with electronic communication are still in an early stage of testing.

Another possible explanation for the discrepancy is that many electronic communication projects failed, and nobody wants to present failures. Indicative for this last explanation is our result that 25 publications described only positive effects, 4 publications described negative effects and 1 publication described only negative effects. The negative effects were: information overload for physicians [40], no cost savings $[26,40]$, the lack of confidentiality $[21,23,40]$, an increase in workload of consultants [17], and the existing discrepancy in work patterns between physicians [26]. The lack of cost savings, however, conflicts only with effects described in other studies in our search.

A third possible explanation is that the effects are of such a complexity that they are hard to measure. This, however, is not limited to the domain of electronic communication. In the medical domain measuring the impact of an intervention in terms of patient outcome is often exceedingly difficult.

A fourth explanation could be that the impact of electronic communication can never be measured because electronic communication in and of itself has little or no impact. The underlying reasoning is that the introduction of electronic communication is such a complex and multi-facetted endeavor that the individual contribution of electronic communication cannot be measured. Also in our results we found that the switch from paper-based communication to electronic communication brings about more changes than just a 'paper' to 'file' conversion $[14,25,26,30,42]$. The switch to electronic communication completely alters the processes in which messages are created and handled. On the other hand, an IT project cannot be turned into a success without accompanying changes in work patterns and responsibilities. 
Our final conclusion is that the literature so far has not demonstrated that the positive effects in the quality of health care can be explained by electronic communication as such. Further research in evaluating communication between GPs and specialists, in combination with the outcome of discussions between members of these professions, is vital to implement strategies of electronic communication in the future. 


\section{References}

1. W.J. van der Kam, P.J. Branger, J.H. v. Bemmel, B. Meyboom-de Jong. Communication between physicians and with patients suffering from breast cancer. Fam. Pract. 15 (1998) 415-419.

2. J.C. van der Wouden, H.J. Dokter. Samenwerking tussen huisarts en specialist bij patiënten met kanker (Collaboration between GP and specialist in patients with cancer, in Dutch). Huisarts Wet. 32 (1989) 51-55.

3. P.J. Branger, J.C. van der Wouden, J.S. Duisterhout, J. van der Lei. Problems in communication between general practitioners and internal medicine consultants. Med. Inform. 20 (1995) 45-51.

4. J.P. Hampson, R.I. Roberts, D.A. Morgan. Shared care: a review of the literature. Fam. Pract. 13 (1996) 264-279.

5. R.J. Mageean. Study of discharge communications from hospital. Br. Med. J. 293 (1986) 1283-1285.

6. E.I. Williams, F. Fitton. General practitioner response to elderly patients discharged from hospital. Br. Med. J. 300 (1990)159-161.

7. L. Irazabal Olabarrieta, B. Gutierrez Ruiz. Does the communication between primary and secondary levels function? Aten. Primaria 17 (1996) 376-381.

8. N.J. Clinger, T.B. Hunter, B.J. Hillman. Radiology reporting: attitudes of referring physicians. Radiology 169 (1988) 376-381.

9. P.W. Moorman, P.D. Siersema, A.M. van Ginneken, M. van Blankenstein. Are referring physicians satisfied with endoscopy reports? Z. Gastroenterol. 32 (1994) 623-625.

10. R.F. Westerman, F.M. Hull, P.D. Bezemer, G. Gort. A study of communication between general practitioners and specialists. Br. J. Gen. Pract. 40 (1990) 445-449.

11. M. Khoury, L. Burnett, M.A. Nackay. Error rates in Australian chemical pathology laboratories. Med. J. Aust. 165 (1996) 128-130.

12. P.J. Branger, A. van 't Hooft, J.C. van der Wouden, J.S. Duisterhout, J.H. van Bemmel. Shared care for diabetes: supporting communication between primary and secondary care. Medinfo 9 (1998) 412-416.

13. P.J. Branger, A. van 't Hooft, J.C. van der Wouden, P.W. Moorman, J.H. van Bemmel. Shared care for diabetes: supporting communication between primary and secondary care. Int. J. Med. Inf. 53 (1999) 133-142.

14. A. Ament, M. M. L'Ortye. An economic evaluation in health care (3I-project). In Telematics in Medicine (Eds: J.S. Duisterhout, A. Hasman and R. Salamon), NorthHolland, 1991, pp. 130-134.

15. G. Arnone, A. Bianchi, B. Della Pietra, R. Sernicola, E. Sparacino, R. Vitolo. Easy Medic: an Internet application for the general practitioner. J. Telemed. Telecare. 4 (Suppl. 1) (1998) 93-94.

16. P.S. Athwall, P. Martin. Use of international data communications standards in hospital laboratories. Proc. Annu. Symp. Comput. Appl. Med. Care (1991) 521-525.

17. G.R. Bergus, S.D. Sinift, C.S. Randall, D.M. Rosenthal. Use of an E-mail curbside consultation service by family physicians. J. Fam. Pract. 47 (1998) 357-360.

18. R. Beuscart, D. Delerue, J.M. Geib. A regional university hospital in the framework 
of a regional information network: the experience of Lille. Stud. Health. Technol. Inform. 56 (1998) 43-51.

19. P.J. Branger, J.C. van der Wouden, B.R. Schudel, E. Verboog, J.S. Duisterhout, J. van der Lei, J.H. van Bemmel. Electronic communication between providers of primary and secondary care. Br. Med. J. 305 (1992) 1068-1070.

20. P.J. Branger, J.S. Duisterhout. Communication in health care. Methods Inf. Med. 34 (1995) 244-252.

21. J.S. Briggs, M.P. Bradley. Lessons learned from an Internet GP information system. Med. Inform. 23 (1998) 245-252.

22. F. Cerne. Hospital develops system to track indigent care. Hospitals 67 (1993) 65 .

23. F. Fisher, B. Madge. Data security and patient confidentiality: the manager's role. Int. J. Biomed. Comput. 43 (1996) 115-119.

24. E.A. Franken Jr., K.S. Berbaum, W.L. Smith, P. Chang, C. Driscoll, G. Bergus. Teleradiology for consultation between practitioners and radiologists. Clin. Chim. Acta 222 (1993) 141-145.

25. P. Guerette, B. Robinson, W.P. Moran, C. Messick, M. Wright, J. Wofford, R. Velez. Teleform scannable data entry: an efficient method to update a community-based medical record? Community care coordination network Database Group. Proc. Annu. Symp. Comput. Appl. Med. Care (1995) 86-90.

26. A. Hasman, A. Ament, P.C. Arnou, A.C.A. van Kesteren. Inter-institutional information exchange in healthcare. Int. J. Biomed. Comput. 31 (1992) 5-16.

27. O.M. Kinkhorst, A. Hasman, A.C.A. van Kesteren. Standardization of data interchange in health care. In Telematics in Medicine (Eds: J.S. Duisterhout, A. Hasman and R. Salamon), North-Holland, 1991, pp. 313-326.

28. C.J. Kooijman, M.E. Kaag. Sending specialist reports to GPS using EDI. Medinfo 9 (1998) 408-411.

29. J.F. Kulik, X. de la Tribonniere, N. Bricon-Souf, R.J. Beuscart, Y. Mouton. Telemedicine for AIDS patients accommodations. Proc. AMIA Annu. Fall Symp. (1997) 379-382.

30. L. Labreze, P. Lagouarde, C. Dakin, J.L. Renaud-Salis. A web interface for multimedia electronic patient record: consensual validation of the Aquitaine Health Information Network prototypes. Med. Inform. 23 (1998) 75-84.

31. M.S. Lundy, W.E. Hammond, D.F. Lobach. Documented data delivery: design, deployment, and decision. In: Proceedings of the 1996 AMIA Fall Symposium (1996) 807-811.

32. G.J. McNeil. Mercy delivers with mobile technology. Health Manag. Technol. 18 (1997) 29.

33. S.N. Murphy, T. Ng, D.F. Sittig, G.O. Barnett. Using web technology and Java mobile software agents to manage outside referrals. Proc. AMIA Symp. (1998) 101-105.

34. T.R. Nelson, A.L. Kellner. High-performance clinical patient data review and consultation system. Stud. Health. Technol. Inform. 39 (1997) 289-297.

35. S. Pazzi S.P. Cristiani, A. Cavallini. A national neurological excellence centers network. Cephalalgia 18 (1998) 70-72.

36. K. Pearl. Pioneering GPs go online to hospitals. Health Trends 21 (1989) 126-128.

37. D.F. Phillips. Physicians put promise of telemedicine to the test: reports from rural practitioners, anesthesiologists. JAMA 276 (1996) 267-268. 
38. F. Pinciroli, L. Portoni, C. Combi, F.F. Violante. WWW-based access to objectoriented clinical databases: the KHOSPAD project. Comput. Biol. Med. 28 (1998) 531-552.

39. M. Pringle. What benefits do general practitioners see in electronic links to hospitals, family practitioner committees and community services? Med. Lab. Sci. 47 (1990) 347-352.

40. B.G. Regan. Computerised information exchange in health care. Med. J. Aust. 154 (1991) 140-144.

41. P.J. Toussaint, M. Kalshoven, M. Ros, H. van der Kolk, O. Weier. Supporting shared care for diabetes patients. The synapses solution. Fam. Pract. 15 (1998) 211-215.

42. O. Weier, M. Kalshoven, H. van der Kolk, F. Leguit, M. Ros, P. Toussaint. The federated healthcare record to support shared diabetes care. Medinfo 9 (1998) 103106.

43. J. Stalhammer, L. Holmberg, K. Svardsudd, G. Tibblin. Written communication from specialists to general practitioners in cancer care. What expectations and how are they met? Scan. J Prim. Health Care 16 (1998) 154-159.

44. L.G. Jacobs, M.A. Pringle. Referral letters and replies from orthopaedic departments: opportunities missed. Br. Med. J. 301 (1990) 470-473.

45. A. Daniels, et al. Benefits of EDI in primary care in the UK. MIE 93 (1993) 443-446.

46. T. Jorgensen, et al. Evaluation of Regional Health Care Networks. MIE 96 (1996) 344-348.

47. P.W. Moorman, K. Bernstein. Regional Health Care Networks in Europe. The CoCo Project report. Odense, 1999, pp. 60-126.

48. A. Wineberg, M. Pritchard. Report to EMEDI; 1997-1998 Data Collection Project on structured electronic healthcare flows. Accessed in December 1999 (1998). pp. http:/www.emedi.com/survey/ 



\section{CHAPTER 3}

\section{Effects of electronic communication between the GP and the pharmacist: The quality of medication data on admission and after discharge}

Accepted by: Family Practice

W.J. van der Kam ${ }^{1.2}$, B. Meyboom-de Jong ${ }^{3}$, Th. F.J. Tromp ${ }^{4}$, P.W. Moorman', J. van der Lei ${ }^{2}$

\footnotetext{
'Isala Clinics, Zwolle, The Netherlands

${ }^{2}$ Dept. of Medical Informatics, Faculty of Medicine and Health Sciences, Erasmus, University, Rotterdam, The Netherlands

${ }^{3}$ Dept. of General Practice, University of Groningen, Groningen, The Netherlands

${ }^{4}$ Dept. of Social Pharmacy and Pharmaco-epidemiology, University of Groningen,

Groningen, The Netherlands
} 



\section{Abstract}

Background: When a patient is admitted to a hospital, the need for information about the medications prescribed is an important issue.

Objectives: To assess whether electronic communication between the general practitioner and the pharmacist provides better information regarding current medication when a patient is admitted to the hospital than paper-based communication.

Method: Prospective study whereby on the day of admission and 10 days after discharge, three different data collectors independently asked the patient, the general practitioner and the pharmacist, respectively, details on the current medication of the patient.

Setting: Five general practitioners and a local pharmacy rely on electronic communication, and 5 general practitioners and a local pharmacy rely on paperbased communication.

Results: A total of 139 patients were included on the first day of their admission, and 116 on the tenth day after discharge. Of the 275 drugs that the patient, the general practitioner and/or the pharmacist reported on admission in the electronic group, $134(49 \%)$ were reported by the patient, the general practitioner as well as the pharmacist; and $79(29 \%)$ were not reported by the patient. For the paper group, these figures were 340 drugs on admission, of which $107(31 \%)$ were reported by the patient, and also the general practitioner, and the pharmacist; while $130(38 \%)$ were not reported by the patient.

Conclusions: We conclude that electronic communication between the GP and the community pharmacist results in a better agreement between the general practitioner and the pharmacist with respect to the current medication of the patient than the paper-based communication. However, electronic communication does not suffice as a solution to obtain reliable information.

Keywords: $\quad$ Electronic communication; Computer communication networks; Family practice; General practitioner; Pharmacist; Medication

\section{Introduction}

In The Netherlands, the GP acts as a gate keeper between primary and secondary care. Each patient also has a community pharmacist for delivering the medication prescribed by the GP or the specialist in the outpatient clinic. As the number of health-care workers providing care to an individual patient increases, the need for communication about the medications prescribed becomes an important issue $[1,2]$. 
When a patient is admitted to a hospital, the medical staff has to determine the current medication of the patient. To obtain that information, the medical and nursing staff often rely on different sources of information, such as the patient, relatives of the patient, the general practitioner, or the pharmacist. The accuracy of information on the current medication, however, varies. Different health-care workers often provide dissimilar information on drugs and dosage prescribed $[3,4]$. In addition, Schiphorst et al. [5] showed that when the patient was asked directly, information was inaccurate in almost half of the cases. Potential reasons for dissimilar information are: the patient uses medication independently of the physician (for example, 'borrowing' a friend's or relative's tablets) [6], patient confusion [7], and inadequate communication between the GP, the pharmacist, and the specialist [8]. Dissimilar information may lead to risks due to discontinuation of the existing therapy, an overdose of the existing therapy, unexpected drug interactions, and increased surgery risks (for example, the surgeon is unaware of anticoagulant therapy) $[3,4]$.

During hospitalisation, the medication is often changed $[7,8]$. Therefore, after a patient has been hospitalised, other care providers, such as general practitioners, need to be informed of these changes. In The Netherlands, the patient receives on discharge prescriptions that are subsequently filled by the community pharmacist. In addition, the specialist in the hospital will, typically, send in a discharge letter to the general practitioner documenting, amongst other, the medication on discharge. However, studies, have shown that when the patient contacts the GP after discharge, the GP is in $45 \%$ of the cases unaware of the changes in medication during that admission [5].

Researchers have argued that electronic communication may improve the quality of patient data $[1,2,10-14]$. In a recent review paper, van der Kam et al. [15] conclude that electronic communication with GPs is faster than paper-based communication. Evidence that the quality of data is improved by electronic communication, is, however, lacking [15]. In the region of Zwolle, a number of general practitioners are using electronic communication to communicate with pharmacists, whereas other general practitioners rely on paper-based communication.

In this study, we first analyse the information on medication provided by the patient, the general practitioner and the pharmacist on admission and after discharge of that patient. We subsequently evaluate whether the method of communication (paper-based versus electronic) is associated with improved quality of patient data regarding medication.

\section{Methods}

All general practitioners (five in total), in the small village of 10,500 inhabitants rely on electronic communication with the local pharmacy to transfer data about prescriptions. The GP uses an electronic patient record when writing a 30 
prescription, and this prescription is subsequently sent electronically to the pharmacist. After the prescription has been filled, the pharmacist sends an electronic conformation to the GP. When the pharmacist fills a prescription from the specialist, the pharmacist also informs the GP by sending an electronic message. We shall refer to these five general practitioners and the local pharmacist as the electronic group. The next village (11,500 inhabitants) also has five general practitioners and another local pharmacy. These GPs, however, rely on paper-based communication with the pharmacy: a prescription on paper is given to the patient, and the pharmacist fills that prescription. The general practitioner does not receive a confirmation from the pharmacist. We shall refer to these 5 general practitioners and the local pharmacist as the paper-based group.

In this study we collected information from the GP, the community pharmacist, and the patient, on the current medication of the patient on admission into the hospital, and, again 10 days after his/her discharge. From February 1998, through May 1998, all patients admitted on office days from 8.00 a.m. till 17.00 p.m. in the hospital De Weezenlanden were asked who their GP was. If the general practitioner was either a member of the electronic or paper-based group, the patient was eligible for the study.

If the patient was eligible, the patient was asked whether members of the staff were allowed to contact both the general practitioner and the pharmacist to obtain information about the current medication (informed consent). The second eligibility criterion was that both the general practitioner and the pharmacist had to be available for questioning that same day. If the patient agreed to participate, and both the general practitioner and the pharmacist were available, three different data collectors independently asked on the day of admission the patient, the general practitioner, and the pharmacist details on the current medication. Ten days after discharge of the patient, the same data were again collected using the same method.

\subsection{Analysis}

The drugs were coded according to the Anatomical Therapeutic Chemical (ATC) classification (7 digits). In the ATC classification, a drug with different names but with the same active substance has the same ATC code. Through the analysis, we called drugs identical if the ATC code was the same on the 7 digit level.

We first calculated the mean number of drugs (and SD) reported by the patient, the general practitioner and the pharmacist, respectively, and compared the electronic and the paper-based group, using the Chi-squared test.

For the drugs reported by the patients, we compared whether the patient, the general practitioner, and the pharmacist reported the same drugs, and we compared the electronic and paper group using the Chi-squared test. We, subsequently, 
compared the drugs not reported by the patient; and we compared the electronic group with the paper-based group using the Chi-squared test.

Statistical analysis was done with the software package SPSS/PC+ data entry II.

\section{Results}

A total of 153 patients granted informed consent. For the patient to be included in the study, however, both the general practitioner and the pharmacists had to be available; a total of 139 patients could be included on the first day of their admission, and 116 on the tenth day after discharge.

Of the 139 patients included on admission, 65 patients were enrolled in the practices of the general practitioners in the electronic group, and 74 in the paperbased group. Of the 116 patients included 10 days after discharge, 54 were enrolled in the practices of the general practitioners in the electronic group, and 62 in the paper-based group.

In this study, we obtained information from the patient, the general practitioner, and the pharmacist. Table 1 shows the mean number of drugs (and SD) reported by the patient, the general practitioner, and the pharmacist. As shown in Table 1, patients from the electronic group reported, on average, to be using 3.0 different drugs on admission. The general practitioners of these patients, however, reported that these patients were using on average 3.4 drugs on admission, and the pharmacist 3.3. The differences between the electronic and the paper group on admission and between the electronic and the paper group 10 days after discharge are not significant.

For the drugs mentioned and not mentioned by the patient on admission and 10 days after discharge, Table 2 and Figure 1 show the agreement with the general practitioner and the pharmacist. In total, the patients in the electronic group reported $196(71 \%)$ drugs on admission, while 79 (29\%) drugs were not reported on admission.

As shown in Table 2, of the 196 drugs reported on admission by the patients in the electronic group at this time, $134(49 \%)$ were also reported by both the general practitioner and the pharmacist, $15(5 \%)$ were reported by the general practitioner

Table 1

Mean number of drugs (and SD) on admission and 10 days after discharge according to the patient, the general practitioner and the pharmacist.

\begin{tabular}{|c|c|c|c|c|c|c|c|c|}
\hline & \multicolumn{4}{|c|}{ On admission } & \multicolumn{4}{|c|}{10 days after discharge } \\
\hline & \multicolumn{2}{|c|}{ Electronic group } & \multicolumn{2}{|c|}{ Paper group } & \multicolumn{2}{|c|}{ Electronic group } & \multicolumn{2}{|c|}{ Paper group } \\
\hline & \multicolumn{2}{|c|}{$n=65$} & \multicolumn{2}{|c|}{$n=54$} & \multicolumn{2}{|c|}{$n=74$} & \multicolumn{2}{|c|}{$n=62$} \\
\hline & Mean & SD & Mean & SD & Mean & $\overline{\mathrm{SD}}$ & Mean & SD \\
\hline Patient & 3.0 & 3.4 & 2.9 & 2.5 & 4.2 & 4.8 & 3.2 & 2.6 \\
\hline GP & 3.4 & 3.3 & 3.2 & 2.7 & 4.4 & 4.1 & 3.5 & 2.8 \\
\hline Pharmacist & 3.3 & 3.3 & 3.0 & 2.3 & 4.0 & 3.7 & 3.5 & 2.5 \\
\hline
\end{tabular}


Table 2

For the drugs, reported and not reported by the patient, the agreement with the general practitioner and the pharmacist.

\begin{tabular}{|c|c|c|c|c|c|c|c|c|}
\hline & \multicolumn{4}{|c|}{ On admission } & \multicolumn{4}{|c|}{10 days after discharge } \\
\hline & \multicolumn{2}{|c|}{ Electronic group } & \multicolumn{2}{|c|}{ Paper group } & \multicolumn{2}{|c|}{ Electronic group } & \multicolumn{2}{|c|}{ Paper group } \\
\hline & $\mathrm{n}$ & $\%$ & $\mathrm{n}$ & $\%$ & $\mathrm{n}$ & $\%$ & $\mathrm{n}$ & $\%$ \\
\hline $\begin{array}{l}\text { Total reported by } \\
\text { patient }\end{array}$ & 196 & 71 & 210 & 62 & 200 & 71 & 198 & 62 \\
\hline $\begin{array}{l}\text { Both GP and } \\
\text { pharmacist agreed } \\
\text { with the patient }\end{array}$ & 134 & 49 & 107 & 31 & 149 & 53 & 105 & 33 \\
\hline $\begin{array}{l}\text { Only GP agreed with } \\
\text { patient }\end{array}$ & 15 & 5 & 30 & 9 & 17 & 6 & 33 & 10 \\
\hline $\begin{array}{l}\text { Only pharmacist } \\
\text { agreed with patient }\end{array}$ & 11 & 4 & 30 & 9 & 9 & 3 & 33 & 10 \\
\hline $\begin{array}{l}\text { Only reported by } \\
\text { patient }\end{array}$ & 36 & 13 & 43 & 13 & 25 & 9 & 27 & 9 \\
\hline $\begin{array}{l}\text { Total not reported by } \\
\text { patient }\end{array}$ & 79 & 29 & 130 & 38 & 81 & 28 & 118 & 38 \\
\hline $\begin{array}{l}\text { Reported by GP and } \\
\text { pharmacist }\end{array}$ & 54 & 20 & 49 & 14 & 40 & 14 & 34 & 11 \\
\hline Only reported by GP & 13 & 5 & 44 & 13 & 26 & 9 & 40 & 13 \\
\hline $\begin{array}{l}\text { Only reported by } \\
\text { pharmacist }\end{array}$ & 12 & 4 & 37 & 11 & 15 & 5 & 44 & 14 \\
\hline $\begin{array}{l}\text { Total reported and } \\
\text { not reported by } \\
\text { patient }\end{array}$ & 275 & 100 & 340 & 100 & 281 & 100 & 316 & 100 \\
\hline
\end{tabular}

only, $11(4 \%)$ by the pharmacist only, and $36(13 \%)$ were reported only by the patient (that is, neither the general practitioner nor the pharmacist reported that patient used that particular medication). In comparing the electronic group with the paper-based group, it is clear that the agreement of the general practitioner and the pharmacist with the patient is significantly higher in the electronic group (49\% versus $31 \%$ on admission, and $53 \%$ versus $33 \% 10$ days after discharge; $\mathrm{p}<0.001$ ). Table 2 also shows that there is no significant difference between the electronic and the paper-based group with respect to the number of drugs mentioned by the patient alone (13\% versus $13 \%$ on admission, and $9 \%$ versus $9 \% 10$ days after discharge). 
Electronic group: $n=275$

General Practitioner

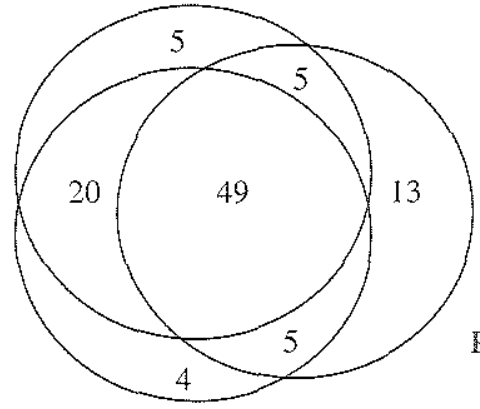

Pharmacist

\section{On admission}

Paper group: $\mathrm{n}=340$

Patient

General Practitioner

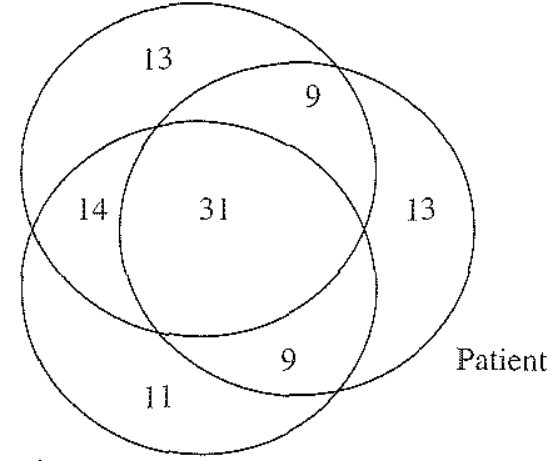

Pharmacist

\section{0 days after discharge}

Electronic group: $\mathrm{n}=281$

General Practitioner

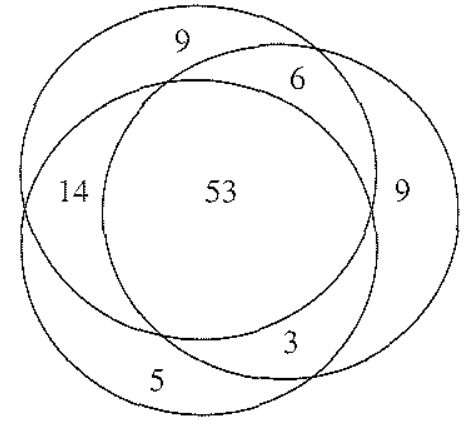

Pharmacist
Paper group: $\mathrm{n}=316$

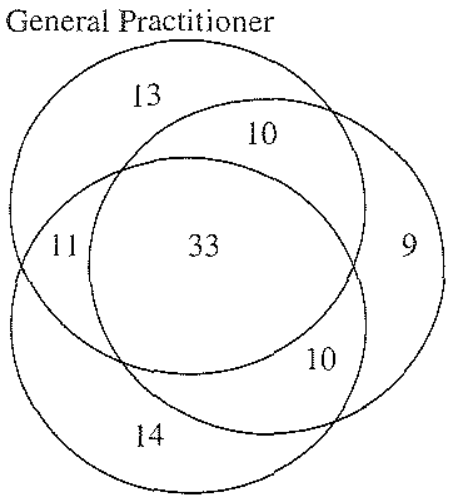

Patient

Figure 1: For the drugs reported by the patient, the general practitioner and the pharmacist on admission and 10 days after discharge, the percentage of agreement among patient, general practitioner and pharmacist.

Table 3 shows the drugs most frequently reported and those not reported at all by the patient. Of the 196 drugs reported by the patient, the five most frequently reported drugs were Aspirin, metoprolol tartrate, simvastine, isosorbide dinitrate and acenocoumarol. 
Table 3

Of the drugs reported by the patient and not reported by the patient cumulated on admission and 10 days after discharge, the five most frequent drugs (number of times mentioned).

\begin{tabular}{|c|c|c|}
\hline & \multicolumn{2}{|c|}{ On admission and 10 days after discharge } \\
\hline & Electronic group & Paper group \\
\hline \multirow{6}{*}{$\begin{array}{l}\text { Reported by the } \\
\text { patient }\end{array}$} & $n=396$ & $n=408$ \\
\hline & B01AC06 Aspirin (18) & C07AB02 Metoprolol tartrate (23) \\
\hline & C07AB02 Metoprolol tartrate (17) & B01 AC06 Aspirin (21) \\
\hline & B04AB01 Simvastin (13) & B01 AC08 Carbaspirin calcium (16) \\
\hline & C01DA08 Isosorbide dinitrate (10) & B01AA07 Nicoumalone (15) \\
\hline & B01AA07 Nicoumalone $(10)$ & A02BC01 Omeprazol (12) \\
\hline \multirow{6}{*}{$\begin{array}{l}\text { Not reported by the } \\
\text { patient }\end{array}$} & $n=160$ & $\mathrm{n}=248$ \\
\hline & N02BE01 Paracetamol (7) & B01AC06 Aspirin (12) \\
\hline & B01AC06 Aspirin (5) & M01AE01 Ibuprofen (11) \\
\hline & S01BC03 Diclofenac (4) & R03AC02 Salbutamol (11) \\
\hline & C08CA05 Nifedipine (4) & C01DA02 Glyceryl trinitrate (10) \\
\hline & C08DA01 Verapamil (4) & N05BA04 Oxazepam (10) \\
\hline
\end{tabular}

\section{Discussion}

Optimal medical care for patients requires adequate communication among physicians involved in that care $[1,2]$. In this study, the setting was the admission of patients to a hospital. Hospital staff requires accurate information concerning the current medication of admitted patients, information that can be obtained from the patient, the general practitioner, or the pharmacist. The objective of this study was to assess whether electronic communication between the general practitioner and the pharmacist provides better information regarding current medication when a patient is admitted to the hospital than paper-based communication.

We conclude that electronic communication between the GP and the community pharmacist results in a better agreement between the general practitioner and the pharmacist with respect to the current medication of the patient than the paperbased communication. For the drugs reported by the patient, the agreement between the general practitioner and the pharmacists was higher in the electronic group when compared with the paper-based group. For the drugs reported by the patient only (that is, neither the general practitioner nor the pharmacist reported that the patient was using that specific medication), no difference between the 
electronic and the paper-based group could be found (on admission, 13\% in both groups and 10 days after discharge, $9 \%$ in both groups).

Our second conclusion is that electronic communication between the GP and the community pharmacist does not eliminate the problem of dissimilar information reported by the GP, the community pharmacist, and the patient. Our study confirms other research which also reports the discrepancy between information obtained from the patient, the physician, and the pharmacist $[5,8]$. The discrepancies between current medication as reported by the patient and current medication as reported by the general practitioner or the pharmacist is not limited to OTC ('over the counter') products. The patient did not report important drugs as, e.g., glyceryl trinitrate, nifedipine, salbutamol and verapamil.

In the electronic group, the GP and the community pharmacist share their information concerning drugs. We, therefore, expected a nearly total agreement between the general practitioner and the pharmacist. We, however, observed, agreement between the general practitioner and the pharmacist in only $79 \%$ of the drugs on the admission of the patient. Possible reasons for disagreement between the general practitioner and the pharmacist when electronic communication is available include failure to consistently record changes (e.g., during house calls), failure to explicitly code the discontinuation of drugs (e.g., the general practitioner records changes in medication in free text), and patient non-compliance (e.g., the pharmacist recognises that the patient is not regularly filling his or her prescriptions). Further research has to clarify the mechanisms involved.

From a practical viewpoint, our study underscores the problems faced by the staff of a hospital when a patient is admitted. Reliable information on current medication is essential, but hard to obtain. When the patient is not able to answer questions, alternative sources such as the general practitioner or the pharmacist can be called upon. Our study indicates that the hospital staff will then receive information that includes drugs that would not have been reported by the patient him or herself. In our study, for example, 11 patients did not report salbutamol. In addition, other drugs the patient would have reported will not be reported. Although the presence of electronic communication between the general practitioner and the pharmacist will improve the agreement of data between the general practitioner and the pharmacist, the agreement between the patient and care providers is not influenced. Besides, it doesn't matter which of the care providers is called by the hospital staff when a patient is not able to communicate with the staff.

We want to point out that the findings of this study are probably optimistic; we did not include patients during weekend and night shifts, and the patients originate from geographically well-defined areas where the same pharmacist is always available to fill the prescriptions. In towns, where patients may visit different pharmacists, we would expect poorer results.

In summary, we conclude that electronic communication has improved the quality of data on the current medication as reported by the general practitioner and the 
pharmacist. Electronic communication, however, does not suffice to obtain reliable information. Further research will have to study the impact of additional measures aimed at improving communication [16].

\section{Acknowledgements}

We gratefully acknowledge the support of the participating general practitioners and pharmacists. We also thank the colleagues H.G. Grotenhuis and H.E.P. Bosveld for their contributions to the study. We finally acknowledge the financial support of the Fonds Doelmatige Farmaceutische Zorg (DFZ). 


\section{References}

1. Branger PJ, van der Wouden JC, Schudel BR, Verboog E, Duisterhout IS, van der Lei $J$, et al. Electronic communication between providers of primary and secondary care [see comments]. Br Med J 1992;305:1068-1070.

2. Schiff GD, Rucker TD. Computerized Prescribing. Building the electronic infrastructure for better medication usage. JAMA 1998;279:1024-1029.

3. Cochrane RA, Mandal AR, Ledger-Scott M, Walker R. Changes in drug treatment after discharge from hospital in geriatric patients. Br Med J 1992;305:694-696.

4. Price D, Cooke J, Singleton S, Feely M. Docters' unawareness of the drugs their patients are taking: a major cause of overprescribing? Br Med J 1986;292:99-100.

5. Schiphorst PP, Benraad HB, Muller NF. Medicatie bij opname in en ontslag uit ziekenhuis. Vergelijking van vier bronnen van medicatiegegevens (Admission and discharge medications. Comparison of four sources of medication data, in Dutch). Pharm. Weekbl. 1992;127:128-132.

6. Hosie GAC, Hosie J. Informing the hospital of patients drug regiments. $\mathrm{Br} \mathrm{Med} J$ 1986;292:628.

7. Gonski PN, Stathers GM, Freiman JS, Smith T. A critical review of admission and discharge medications in an elderly Australian population. Aging 1993;3:358-362.

8. Hampson JP, Roberts RI, Morgan DA. Shared care: a review of the literature. Fam Pract 1996;13:264-279.

9. Himmel W, Tabache M, Kochen MM. What happens to long-term medication when general practice patients are referred to hospital? Eur J Clin Pharmacol 1996;50:253257.

10. Beuscart R, Delerue D, Geib JM. A regional university hospital in the framework of a regional information network: the experience of Lille. Stud Health Technol Inform $1998 ; 56: 43-51$.

11. Branger PJ, van 't Hooft A, van der Wouden JC, Moorman PW, van Bemmel JH. Shared care for diabetes: supporting communication between primary and secondary care. Int J Med Inf 1999;53:133-142.

12. Chin TL. Health Data Manage1997;5:74-79.

13. Labreze L, Lagouarde P, Dakin C, Renaud-Salis JL. A web interface for multimedia electronic patient record: consensual validation of the Aquitaine Health Information Network prototypes. Med Inform (Lond) 1998;23:75-84.

14 Phillips DF. Physicians put promise of telemedicine to the test: reports from rural practitioners, anesthesiologists [news]. Health Serv J 1997;107(Suppl):17-18.

15. Van der Kam WJ, Moorman PW, Koppejan-Mulder MJ. Effects of electronic communication in general practice. Intern J Med Inform 2000:60;59-70.

16. Heathfield H, Pitty D, Hanka R. Evaluating information technology in healthcare: barriers and challenges. Br Med J 1998;316:1959-1961. 


\section{CHAPTER 4}

\section{Communication between physicians and with patients suffering from breast cancer}

Published in: Family Practice 1998;15:415-419

W.J. van der Kam ${ }^{1.2}$, P.J. Branger ${ }^{2}$, J.H. van Bemmel ${ }^{2}$,

B. Meyboom-de Jong ${ }^{3}$

'Isala Clinics, Zwolle, The Netherlands

${ }^{2}$ Dept. of Medical Informatics, Faculty of Medicine and Health Sciences, Erasmus University, Rotterdam, The Netherlands

"Dept. of General Practice, University of Groningen, Groningen, The Netherlands 



\begin{abstract}
Background: The communication between GP and specialists is vital for the patient suffering from breast cancer.

Objectives: The aim of this study was to investigate (1) the speed and type of communication between general practitioners (GPs), specialists and patients with breast cancer, and (2) the problems that GPs encounter in the communication with specialists concerning these patients.

Method: In April 1995, 246 Dutch GPs from the Zwolle region $(600,000$ inhabitants) were invited to complete a questionnaire, using the information from the medical record and focusing on the last patient consulted with a confirmed diagnosis of breast cancer.

Results: Valid replies were received from $150(61 \%)$ GPs. The median period between initial referral date and receipt of the definite diagnosis from the surgeon was 4 weeks. After the patient's first appointment with the surgeon, the GPs received reports for $24 \%$ of the patients within 3 days; for $31 \%$ within 3-7 days; and for $16 \%$ of the patients after more than 2 weeks. After the first consultation between patient and surgeon, $68(45 \%)$ of the 150 GPs reported that the patient contacted them; at this stage only $30(20 \%)$ of these GPs had received a report from the surgeon. Thirty-one ( $21 \%$ ) GPs did not contact the patient after receipt of the definite diagnosis. GPs stated that the communication on patients with breast cancer is too slow (49\%), or not frequent enough (25\%); $25 \%$ of GPs found that the distribution of tasks between them and the specialists are not well described.

Conclusion: In the diagnostic stage of breast cancer the communication between GPs, specialists and patients varies widely, is too slow, and incomplete. An effect of this unsatisfactory communication is that the patient herself is the messenger of the bad news.
\end{abstract}

Keywords: $\quad$ Breast cancer; Communication; Family practice; General practitioner; Medical oncology

\title{
1. Introduction
}

In The Netherlands, all patients first consult their general practitioner (GP) who operates in a primary-care setting and handles $90 \%$ of all patient problems independently, i.e., without referring to a specialist. If deemed necessary, the patient is referred to a specialist of the GP's choice. The specialist reports back to the GP after examination and/or treatment of the patient.

Patients suffering from cancer need unambiguous advice and information about various aspects of their disease. This information is vital for the support of the 
patient $[1,2]$. From the onset of the disease, the psychological balance of the patient is disturbed, often leading to feelings of panic, despair, fear and depression $[3,4]$. Patients with cancer are often seen by different physicians, including GPs, radiologists and surgeons. Particularly in this group of patients, the more frequent the communication between the physicians involved and the better their tasks defined, the more positive their opinions on the collaboration [5] and the better the continuity of care [6].

Several types of communication problem are known to exist between GPs and specialists [5,7]. Branger et al. reported that communication problems mainly arise from too late delivery of information and lack of understanding of the information needs of the GP by the specialists [6]. Concerning written communication, referral letters from GPs and discharge letters from specialists have often been the subject of research [8-13]. However, in communication on patients suffering from breast cancer, little is known about the speed and type of communication, and the problems experienced by physicians and patients. In communicating on such patients, several stages can be distinguished. In this study we concentrated on the first stage: the communication on the diagnosis and the initial medical treatment [14]. During this stage the GP refers the patient for diagnostic examinations and treatment to a radiologist and/or a surgeon. At this stage, the patient is in a state of uncertainty about the prognosis [14-15]. Medical procedures during this first stage are well structured, but communication between care providers and with patients is only vaguely defined.

In order to obtain insight into existing communication problems between care providers and patients, we investigated:

1. The speed and type of communication between GPs, specialists (radiologists and surgeons) and patients with breast cancer in the period starting from the first referral by the GP to the specialist, to receipt by the GPs of the definite diagnosis based on the pathology report, and

2. Bottlenecks and problems that GPs encounter in the communication with specialists concerning patients with breast cancer.

\section{Methods}

The study was performed in The Netherlands in the Zwolle region in April 1995. This region is a predominantly rural area with about 600,000 inhabitants, seven hospitals and 250 GPs. A total of 247 GPs, who referred in 1994 patients suffering from breast cancer to specialists in hospital 'De Weezenlanden' (one of the two hospitals in the Zwolle region) were asked to complete a paper mail questionnaire. The GPs were requested to answer the questions focusing on their last patient with a confirmed diagnosis of breast cancer and to use their medical record. The first part of the questionnaire focused on the speed and type of communication between GPs, specialists, and patients with breast cancer. 


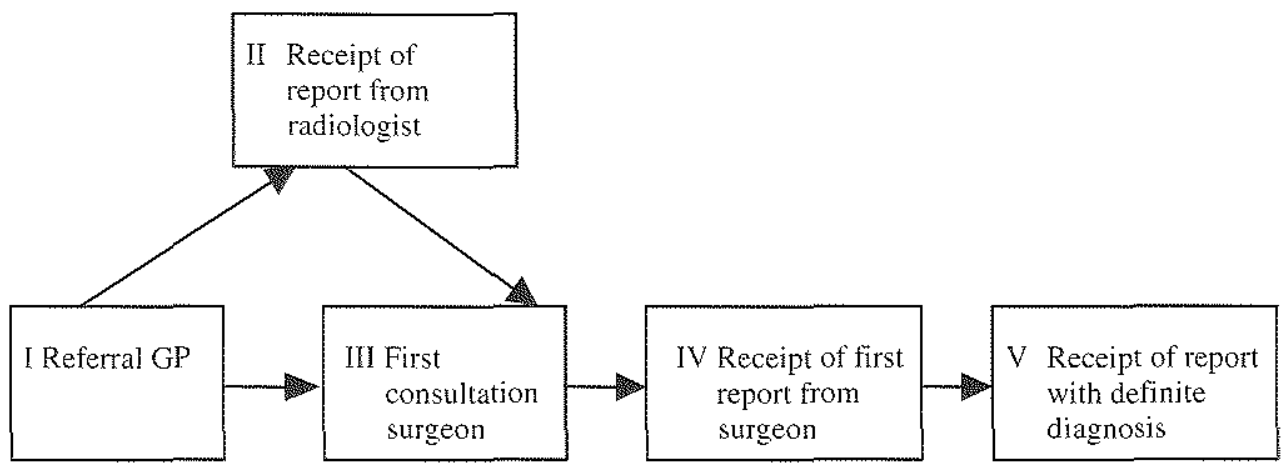

Figure 1.

Figure 1 shows the moments of communication between GPs, specialists and patients in the diagnostic stage of breast cancer. Data were collected on: name of the hospital, date of referral, first visit to the specialist, receipt of the first report by the GP from the specialist, and receipt of the definite diagnosis (results of the pathology examination, including examination of the axillary lymph nodes). In case of referral to a specialist, the type of communication was also noted. Questions concerning the communication between patients and GPs, after the first consultation with the specialist, and the GP's action after receiving the first report, and on the report with the definite diagnosis from the specialist, were also part of the questionnaire. The questionnaire also contained questions on the bottlenecks and problems that GPs encounter in the communication with specialists concerning patients with breast cancer. It is was possible to indicate that the questionnaire could not be fully completed. Multiple responses were allowed for questions related to the type of communication.

Six weeks after mailing the questionnaire, non-responders received a postal reminder. After another 6 weeks the persisting non-responders received a second reminder followed by a telephone call. In the ensuing weeks all non-responders were contacted.

In analysing the data from the questionnaires, means and medians, and minimal and maximal periods between dates were computed. Statistical analysis was done with the software package SPSS/PC+ data entry II.

\section{Results}

A total of $196(80 \%)$ replies were received from the 246 GPs. Of these, 42 GPs $(17 \%)$ were unable to properly complete the questionnaire for the following reasons: the last patient with a confirmed diagnosis of breast cancer was seen too long ago; no patient with breast cancer had been seen; or they had recently started their practice. Four ( $2 \%$ ) questionnaires were not completed for unknown reasons, leaving a total of $150(61 \%)$ valid replies. Of the 150 responders, $89(59 \%)$ 
Table 1

Time from GP referral to first radiology report and to first surgical appointment; time from first surgical appoinment to first surgical report and to definitive surgical report (number of valid answers, median in days, distribution in terms of percentage).

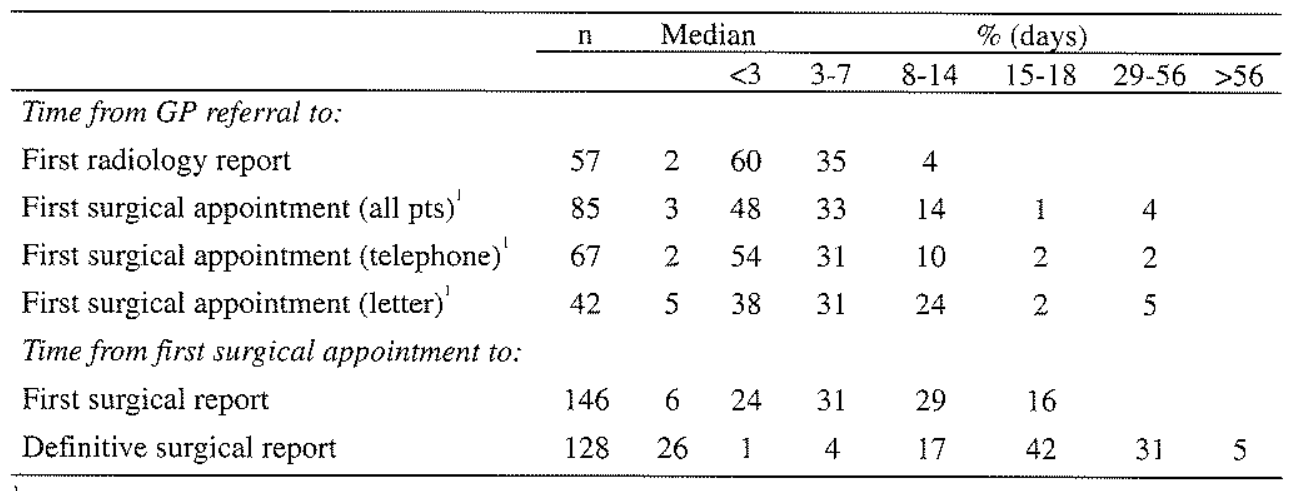

'In cases of referring directly to the surgeon.

referred their last patient with breast cancer to the hospitals in Zwolle, $15(10 \%)$ to the nearby hospital in Meppel, and $46(31 \%)$ to 10 other hospitals in the region; 57 (38\%) referred first to a radiologist and afterwards to a surgeon, and $93(62 \%)$ referred directly to a surgeon.

\subsection{Speed of communication between GP and specialists}

Table 1 shows (1) the time from GP referral to first radiology report and to first surgical appointment and (2) the time from surgical appointment to first surgical report and to definitive surgical report to the GP. In cases of GP referral to radiology, 57 valid answers were given for the time between referral and the first radiology report. The median was 2 days and the distribution in terms of percentage of patients was as follows: $60 \%$ within 3 day, $35 \%$ within $3-7$ days and $4 \%$ within $8-14$ days.

In cases of a direct referral to the surgeon, eight GPs noted that a mamma screening had been performed previously. In 66 cases (44\%), the first report from the surgeon contained the confirmed diagnosis of breast cancer based on the pathology examination.

Eight GPs (5\%) never received a report with the definite diagnosis from the surgeon.

\subsection{Speed of communication between GP and patient}

Of the $150 \mathrm{GPs}, 68(45 \%)$ indicated that the patient took the initiative to contact the GP after the patient's initial visit to the surgeon. At that time only 30 of the 68 


\section{Table 2}

Time from receipt of surgeon's reports to GP contacted the patient (number of GP's contacted the patient, distribution in terms of percentage)

\begin{tabular}{l}
\hline \\
\cline { 2 - 5 }
\end{tabular}

GPs had received a report on the visit to the surgeon. In the remaining 48 cases, the patient often informed the GP of the bad news.

Table 2 shows the time from receipt of surgeon's reports to GP contacted the patient. In case of the time from receipt of the first report to GP contacted the patient 116 GPs indicated that they contacted the patient and the distribution in terms of percentage was: $39 \%$ within 1 day, $60 \%$ within $2-7$ days and $2 \%$ more than 1 week.

The GPs emphasized that it was necessary to see the patient after receipt of the definite diagnosis.

\subsection{Type of communication when referring to surgeon or radiologist}

GPs referred to radiologists by telephone in $11(7 \%)$ cases, wrote a letter in 39 (26\%) cases and did both in $6(4 \%)$ cases. The type of communication was unknown in the remaining 1 case.

GPs referred to surgeons by telephone in $63(42 \%)$ cases, wrote a letter in 35 $(23 \%)$ cases and did both in $46(31 \%)$ cases. Six $(4 \%)$ patients were referred to the surgeon by the radiologist.

\subsection{Informing the GPs about the definite diagnosis}

Table 3 shows that the GP received the first notification of the definite diagnosis in

Table 3

The way general practitioners $(n=150)$ are informed about the definite diagnosis of breast cancer.

\begin{tabular}{lcc}
\hline Type of communication & No. of GPs & $\%$ \\
\hline Telephone & 23 & 15 \\
Discharge letter & 41 & 27 \\
Written note & 61 & 41 \\
During conference & 10 & 7 \\
By patient & 35 & 23 \\
Other & 14 & 9 \\
\hline
\end{tabular}


Table 4

Problems experienced by general practitioners in communication concerning patients with breast cancer.

\begin{tabular}{|c|c|c|c|}
\hline & \multicolumn{3}{|c|}{ Number $(\%)$ of general practitioners } \\
\hline & Yes & No opinion & No \\
\hline \multicolumn{4}{|l|}{ Communication is: } \\
\hline Too slow & $73(49 \%)$ & $5(3 \%)$ & $72(48 \%)$ \\
\hline Too infrequent & $38(25 \%)$ & $13(9 \%)$ & $99(66 \%)$ \\
\hline Incomplete & $30(20 \%)$ & $13(9 \%)$ & $107(71 \%)$ \\
\hline Incorrect & $2(1 \%)$ & $9(6 \%)$ & $139(93 \%)$ \\
\hline Inaccessibility of specialist & $11(7 \%)$ & $10(7 \%)$ & $129(86 \%)$ \\
\hline Tasks not well defined & $37(25 \%)$ & $19(13 \%)$ & $94(63 \%)$ \\
\hline Other bottlenecks & $49(33 \%)$ & none & $101(67 \%)$ \\
\hline
\end{tabular}

different ways: 35 patients informed the GP themselves; 24 GPs spontaneously remarked that the patient being the messenger of the bad news is totally unjustified.

\subsection{Problems encountered by GPs in the communication with specialists}

Problems in communicating with specialists were experienced by 66 GPs (44\%). Table 4 shows that 73 GPs (49\%) stated that the communication was too slow and $38(25 \%)$ found that it was not frequent enough; moreover, $37(25 \%)$ GPs stated that the tasks of primary health care and hospital care were not sufficiently well defined.

\section{Discussion}

As pointed out previously [1,2], the treatment of patients suffering from cancer requires reliable and timely information exchange between health-care professionals and patients. Based on our study we conclude that present communication in the diagnostic stage of breast cancer between GPs, specialists and patients needs clarification and improvement.

Other researchers have pointed out the importance of specialists' reports for general practice [13]. Our inventory of the speed of communication between GPS and specialists has revealed great variability in the interval between (1) the initial referral of patients by the GPs, and (2) the receipt of specialists' reports by the GP. No less than $68(45 \%)$ of the referred patients contacted their GP after the patients initial visit to the surgeon, and $48(32 \%)$ did this before the GP received a first report from hospital. Even the definite diagnosis was delivered to the GP by the patient herself in 35 (23\%) of the cases. This situation places the patient in the role of messenger of the bad news. 
Shifting our focus to the GP, however, we conclude that not in all cases did the GP undertake action towards their patients after receipt of a specialist's report. Of the 150 GPs, $25 \%$ did not initiate contact with the patient within 1 week of receipt of the first report. Of the $150 \mathrm{GPs}, 119(79 \%)$ initiated contact with the patient after receipt of the definite diagnosis; $27 \%$ did this within 1 day. No less than 31 (21\%) GPs, however, did not contact the patient after receiving the definite diagnosis.

In our study, we asked the GPs to express their opinion about the quality of the communication with the specialist. No less than $66(44 \%)$ of the GPs indicated that they experienced problems with the communication from the specialist. The main bottlenecks and problems encountered by GPs in communicating with specialists are because communication is too slow (49\%), too infrequent $(25 \%)$ and incomplete $(20 \%)$; it is noteworthy that $25 \%$ of the GPs stated that the delineation of tasks between themselves and the specialist is not well defined.

One limitation of the present study is that only one region in The Netherlands was covered. Also, there are weaknesses in a retrospective analysis using data derived from medical records, especially when not all considerations and verbal communications are noted. Another limitation of our study is that the opinions of the patients and the specialists were not asked for. Our results, however, are in accordance with those from other studies, i.e., that the communication between GPs and specialists is considered to be inadequate; the usual paper communication is often too late and incomplete $[5,6,11,13]$.

Other researches have shown that patients are less depressed and less uncertain when they are properly informed by their physicians [16]. Especially information about the treatment and its side effects appears to be important [17]. From our study it appears that communication may benefit from specialists and GPs working together, and are linked in a communication chain of messages in the triangle of patient, specialist and GP. Therefore, it seems essential to examine and introduce new ways and means for the communication between care providers and patients (e.g., by electronic communication) [6], and to better delineate and define the tasks of GPs and specialists.

\section{Acknowledgements}

We gratefully acknowledge the support of the participating GPs in the Zwolle Region. We also thank the colleagues C. Hartman, S.M. Schot and H.E.P. Bosveld for their contributions to the study. 


\section{References}

1. Winnubst JAM, Maes S, eds. Lifestyles, Stress and Health. Leiden: DSWO Press, 1992.

2. Zemore R, Shepel LF. Effects of breast cancer and mastectomy on emotional support and adjustment. Soc Sci Med 1989;28:19-27.

3. Maguire P. Improving the detection of psychiatric problems in cancer patients. Soc Sci Med 1985;20:819-823.

4. Holland JC. Anxiety and cancer: the patient and the family. J Clin Psychiatry 1989;11:20-25.

5. Van der Wouden JC, Dokter HJ. Samenwerking tussen huisarts en specialist bij patiënten met kanker (Collaboration between GP and specialist in patients with cancer, in Dutch). Huisarts Wet 1989;32:51-55.

6. Branger PJ, Wouden JC van der, Duisterhout JS, Lei J van der. Problems in communication between general practitioners and internal medicine consultants. Med Inform 1995;20:45-51.

7. Verhaak PFM. Hoe speciaal is de communicatie van de huisarts? (How special is the communication by the GP?, in Dutch) Huisarts Wet 1991;4:320 324.

8. Engelsman C, Geertsma A. De kwaliteit van Verwijzingen (The Quality of Referrals. Ph.D. thesis, in Dutch). Groningen: State University of Groningen, 1994.

9. Zock AL, Leeuwenburg J, Pleumeekers H. De verwijsbrief getoetst. (Assessing the referral letter, in Dutch) Huisarts Wet 1989;32:505-508.

10. Williams EI, Fitton F. General practitioner response to elderly patients discharged from hospital. Br Med J 1990;300:159-161.

11. Penney TM. Delayed communication between hospitals and general practitioners: where does the problem lie? Br Med J 1988;297:28-29.

12. Sandler DA, Mitschell JRA. Interim discharge summaries: how are they best delivered to general practitioners? Br Med J 1987;295:1523-1525.

13. Bado W, Williams CJ. Usefulness of letters from hospitals to general practitioners. $\mathrm{Br}$ Med J 1984;288:1813-1814.

14. Weisman AD. A model for psychosocial phasing. Gen Hosp Psychiatry 1979;1:187195.

15. Meredith C, Symonds P, Webster, et al. Information needs of cancer patients in west Scotland: cross sectional survey of patients' views. Br Med J 1996;313:724-726.

16. Steptoe A, Sutclive 1, Allen B, Combes C. Satisfaction with communication, medical knowledge and coping style in patients with metastatic cancer. Soc Sci Med $1991 ; 32: 627-632$.

17. Newall DJ, Gadd EM, Priestman TJ. Presentation of information to cancer patients: a comparison of two centers in the UK and USA. Br J Med Psychol 1987;60:127-131. 


\section{CHAPTER 5}

\section{Communication among physicians when treating patients with suspected breast cancer}

Published in: Cancer Strategy 2000;2:31-34

W.J. van der Kam ${ }^{1.2}$, B. Meyboom-de Jong ${ }^{3}$, P.W. Moorman', J. van der Lei ${ }^{2}$, J. Duitgenius ${ }^{4}$, J.C. van der Wouden ${ }^{4}$

'Isala Clinics, Zwolle, The Netherlands

${ }^{2}$ Dept. of Medical Informatics, Faculty of Medicine and Health Sciences, Erasmus University, Rotterdam, The Netherlands

${ }^{3}$ Dept. of General Practice, University of Groningen, Groningen, The Netherlands

${ }^{4}$ Dept. of General Practice Faculty of Medicine and Health Sciences, Erasmus University, Rotterdam, The Netherlands 



\begin{abstract}
Optimal diagnosis and treatment of patients suffering from breast cancer requires adequate communication between the physicians involved. To obtain insight into existing communication problems between care providers, we investigated: (a) the speed and type of communication between general practitioners, specialists and patients with breast cancer, and (b) bottlenecks and problems that general practitioners encounter in the communication with specialists concerning patients with breast cancer.

A random sample of 235 of the 1200 General Practitioners was asked to complete a paper mail questionnaire in an urban region in The Netherlands.

A total of $126(54 \%)$ valid replies were received from the 235 general practitioners. The average time between referring the patient to the specialist and receiving the report final diagnosis was 35 days. After receiving reports from the surgeon, $70 \%$ of the general practitioners took the initiative to contact the patient. In $30(23 \%)$ cases, the patient was the first to inform the general practitioner about the final diagnosis.

The general practitioners stated that the communication from the specialist is too slow $(39 \%)$ or not frequent enough $(29 \%)$.

We conclude that communication in the diagnostic stage of breast cancer between general practitioners, specialists and patients requires improvement.
\end{abstract}

Keywords: Breast cancer; Communication; General practitioner; Family practice

\title{
1. Introduction
}

Patients suffering from cancer need unambiguous advice and information about the various aspects of their disease from their doctors [1-4]. From the onset of the disease, the psychological balance of the patient is disturbed, often leading to feelings of panic, despair, fear and depression [1,2]. Especially at the diagnostic stage of breast cancer, the patient is in a state of uncertainty about the prognosis $[5,6]$. Information provided by physicians is vital for the support of the patient. Patients with cancer, however, are often seen by different physicians including general practitioners, radiologists and surgeons. The different physicians involved in the treatment of the same patient have to communicate to achieve consistency in cancer care.

We previously studied communication among physicians with respect to patients with breast cancer in the eastern part of The Netherlands [7]. In that study, we concluded that in the diagnostic stage of breast cancer the communication between general practitioners and specialists is too slow and incomplete. In the diagnostic stage, the patient was seen by different physicians. These physicians, however, did 
not adequately inform each other. Lacking information from specialists, the patient herself is for the general practitioner often the source of information about the specialist's diagnosis and treatment. The inadequacy of communication with the specialist and the role of the patient as messenger is illustrated by our finding that in $23 \%$ of the cases studied [7], the patient herself informs the general practitioner about the definitive diagnosis of breast cancer.

The study was limited to one region in The Netherlands. The conclusion that the communication between general practitioners and specialists is inadequate cannot be generalised to The Netherlands a whole based on this study alone. To investigate whether the problems in communication between general practitioners and specialist also exist in other regions of the country, we repeated the same study in a different region. Because the first study was conducted in a predominantly rural region in the eastern part of the country, we conducted our second study in a urban setting in the western part of the country. To obtain insight into existing communication problems between care providers, we investigated: (a) the speed and type of communication between general practitioners, specialists (radiologists and surgeons) and patients with breast cancer in the period starting from the first referral by the general practitioner to the specialist, to receipt by the general practitioners of the final diagnosis based on the pathology report, and (b) bottlenecks and problems that general practitioners encounter in the communication with specialists concerning patients with breast cancer.

\section{Methods}

The study was performed in The Netherlands in a region around the city of Rotterdam. This urban area has 2,000,000 inhabitants, 25 hospitals (one is a university hospital) and 1200 general practitioners. A random sample of 235 of the 1200 General Practitioners was asked to complete a paper mail questionnaire.

In a letter, we requested the general practitioner to retrieve the medical record of his or her most recent patient with a confirmed diagnosis of breast cancer. Based on the medical record of that patient, we subsequently asked the general practitioner to answer a questionnaire.

The first part of the questionnaire focused on the speed and type of communication between general practitioner and specialists. In this part of the questionnaire we asked the general practitioner the date of referral, the name of the hospital referred to, speciality referred to, date of first visit to the specialist, date of receipt of the first report by the general practitioner from the specialist, and date of the receipt of the final diagnosis. In addition, we asked whether the general practitioner communicated with the surgeon by telephone and whether he or she wrote a referral letter.

The second part of the questionnaire contained questions related to the contact between the patient and her general practitioner after referral to the surgeon. We asked the general practitioner whether the patient after her first visit to the surgeon 
took the initiative to contact her general practitioner. If the patient did contact her general practitioner, we asked whether the general practitioner had already any information at all from the specialist.

The third part of the questionnaire contained questions related to the contacts between the general practitioner and the patient after the general practitioner received information from the surgeon. Typically, the surgeon will inform the general practitioner several times in the diagnostic phase. We asked the general practitioner whether, after receiving the first report from the surgeon, he or she took the initiative to contact the patient. In addition, we asked whether the general practitioner took the initiative to contact the patient after receiving the report with the definitive diagnosis from the surgeon.

The fourth part of the questionnaire contained a single question: who was the first person to inform the general practitioner about the final diagnosis of breast cancer. The final part of the questionnaire contained general propositions on the bottlenecks and problems that general practitioners encounter in the communication with specialists concerning patients with breast cancer.

Six weeks after mailing the questionnaire, non-responders received a postal reminder. After another 6 weeks the persisting non-responders received a second reminder followed by a telephone call. In the ensuing weeks all non-responders were contacted.

In analysing the data from the questionnaires, means and medians, and minimal and maximal periods between dates were computed. Statistical analysis was done with the software package SPSS/PC+ data entry II.

\section{Results}

A total of $126(54 \%)$ valid replies were received from the 235 general practitioners. Analysis of non-respondents revealed no significant differences between respondents and non-respondents regarding type of practice, year of establishment, sex and age.

The 126 responders referred to 35 different hospitals in the region. Of the 126 patients, $47(37 \%)$ were referred to a radiologist, $68(54 \%)$ to a surgeon, $5(4 \%)$ to an outpatient clinic for mammography, 3 (2\%) to another specialist, and in $3(2 \%)$ cases the speciality was not known. Patients initially referred to a radiologist or other specialist were eventually referred to a surgeon. Of the 126 cases, the general practitioner used the telephone in $77(61 \%)$ cases to refer the patient the surgeon, and wrote a referral letter for the surgeon in $53(41 \%)$ cases.

General practitioners referred to radiologists by telephone in $14(11 \%)$ cases and wrote a letter in $38(30 \%)$ cases. General practitioners referred to surgeons by telephone in $77(61 \%)$ cases, wrote a letter in $53(41 \%)$ cases, $15(12 \%)$ patients were referred to the surgeon by the radiologist, two patients were referred by an internist and one patient was referred by her husband. The type of communication was unknown in four cases. 
The average time between referring the patient to the specialist and receiving the report final diagnosis was 35 days $(n=103$, median 30 days, SD 23). In 20 cases the time between referral and reception of final diagnosis was not known: in 11 cases, the general practitioner could not determine exactly when the patient was referred, and in 9 cases, the general practitioners never received a report with the final diagnosis from the surgeon.

Of the 126 general practitioners, $76(60 \%)$ indicated that the patient took the initiative to contact the general practitioner after the patient's initial visit to the surgeon. When the patient contacted her general practitioner, only $26(21 \%)$ of the 76 general practitioners had received information from the surgeon.

After receiving a first report from the surgeon, $87(70 \%)$ of the 126 general practitioners took the initiative to contact the patient, $34(27 \%)$ took no initiative to contact the patient, and in $5(4 \%)$ unknown. Of the 87 general practitioners who took the initiative to contact the patient, $26(30 \%)$ contacted the patient the within 24 hours. After receiving the report with the final diagnosis from the surgeon, $88(70 \%)$ of the 126 general practitioners took the initiative to contact the patient, $29(23 \%)$ took no initiative to contact the patient, and in $9(7 \%)$ unknown. Of the 88 general practitioners who took the initiative to contact the patient, $14(16 \%)$ contacted the patient the within 24 hours.

We asked who informed the general practitioner of the final diagnosis. In $87(69 \%)$ of the 126 cases, the specialist was the first to inform the general practitioner about the final diagnosis. In $30(23 \%)$ cases, the patient was the first to inform the general practitioner. In 9 cases $(7 \%)$, the general practitioner did not known who initially informed him or her about the final diagnosis.

The final part of the questionnaire contained general propositions about the communication with specialists concerning patients with breast cancer. Table 1 shows the propositions, and the answers of the general practitioners. Of the general practitioners, $39 \%$ agreed with he proposition "the communication from the specialist is too slow", $46 \%$ disagreed, and $15 \%$ had no opinion (see Table 1).

Table 1

General propositions about the communication with specialists concerning patients with breast cancer answered by general practitioners.

\begin{tabular}{|c|c|c|c|}
\hline \multirow[t]{2}{*}{ Propositions } & \multicolumn{3}{|c|}{ Opinions (\%) } \\
\hline & Yes & $\begin{array}{c}\text { No } \\
\text { opinion }\end{array}$ & No \\
\hline The communication from the specialist is too slow & 39 & 15 & 46 \\
\hline The communication from the specialist is too infrequent & 29 & 18 & 54 \\
\hline The communication from the specialist is incomplete & 10 & 17 & 74 \\
\hline The communication from the specialist is incorrect & 1 & 16 & 83 \\
\hline The accessibility of the specialist is insufficient & 9 & 19 & 72 \\
\hline Tasks among professionals are not well defined & 25 & 29 & 47 \\
\hline
\end{tabular}




\section{Discussion}

Optimal diagnosis and treatment of patients suffering from breast cancer requires adequate communication between the physicians involved. In The Netherlands, most citizens are enrolled in the practice of a general practitioner. When seeking advice or treatment, the patient usually contacts his or her general practitioner, who acts as a gatekeeper in the health-care system. The general practitioner may refer the patient to other specialists if deemed necessary. The specialist reports back to the general practitioner after examination and/or treatment of the patient.

In a previous study, we reported in a region in the eastern part of the country inadequate communication between general practitioner and specialist after referral of patients suspected of breast cancer. The objective of this study was to determine whether inadequacy in communication between general practitioners and specialists observed in a previous study is limited to only a single region of the country. We therefore repeated the study in a region in the western part of the country.

We conclude that in the western part of the country communication in the diagnostic stage of breast cancer between general practitioners, specialists and patients requires improvement. Patients frequently contact their general practitioner before the general practitioner has received information from the specialist; the general practitioner has to communicate with the patient without any knowledge of the specialist's findings. The inadequacy of communication is further is illustrated by our finding that in $23 \%$ of the cases studied, the patient herself informs the general practitioner about the final diagnosis of breast cancer. When asked about the quality of the communication with the specialist, $39 \%$ of the general practitioners judged that communication as too slow and $29 \%$ as too infrequent. We conclude that, although this study was performed in an urban environment, the results are similar to a previous study in the eastern, rural part of the country [7]. Our study focused predominantly on the view of the GP; further research will have to clarify the viewpoints of the patient and the specialist. Our findings, however, correspond with those of other researchers that report problems in the communication between hospital specialists and general practitioners [8-12]. When the specialist informs the general practitioner, the general practitioner will often act on that information: in the majority of cases, the general practitioner initiated contact with the patient after receiving surgical reports. The fact that the general practitioner acts upon these reports of the specialist underscores their importance. Failure to communicate eliminates the opportunity for the GP to initiate contact and contribute the patient's care. In addition, the patient often initiates contact with the GP. The GP, however, often lacks sufficient information. We conclude that although the GP has referred the patient to the specialist, he retains an active role in the patients care. That care requires information, information which is often lacking. 
Although we did not study patient satisfaction or well-being, literature document a number of studies that demonstrate that the poor communication between general practitioner and patient has consequences for the patients satisfaction [13]. Several studies showed a relation between effective communication and improved health outcomes [14]. The outcomes affected were not only emotional health, but also a faster resolution of symptoms and improvement in physiological measures such as blood sugar concentration. Although our study shows that communication between specialist and general practitioner requires improvement, we did not evaluate the consequences of poor communication in terms of patient outcomes. Based on available literature, it seems plausible that improvements in communication would lead to improvement in care. Future studies that aim to improve the communication (e.g., by means of information networks and IT) among physicians may clarify the relationship between good communication and quality of care.

\section{Acknowledgements}

We gratefully acknowledge the support of the participating general practitioners. We also acknowledge the support of the EC Fourth Framework Health Telematics Programme (Projects CoCo and Prompt). 


\section{References}

1. Holland JC. Anxiety and cancer: the patient and the family. J Clin Psychiatry 1989;1 1:20-25.

2. Maguire P. Improving the detection of psychiatric problems in cancer patients. Soc Sci Med 1985;20:819-823.

3. Winnubst JAM, Meas S, eds. Lifestyles, Stress and Health. Leiden: DRO Press; 1992.

4. Zemore R, Shepel LF. Effects of breast cancer and mastectomy on emotional support and adjustment. Soc Sci Med 1989;28:19-27.

5. Meredith $\mathrm{C}$ et al. Information needs of cancer patients in west Scotland: crosssectional survey of patients' views. Br Med J 1996;313:724-726.

6. Weisman AD. A model for psychosocial phasing. Gen Hosp Psychiatry 1979;1:187195.

7. Kam van der WJ, Branger PJ, Bemmel van JH, Meyboom-de Jong B. Communication between physicians and with patients suffering from breast cancer. Fam Pract 1998;15:415-419.

8. Roland M. Communication between GPs and specialists. In: Roland M, Coulter A, eds. Hospital referrals. Oxford: Oxford University Press, 1992.

9. Bado W, Williams $\mathrm{CJ}$. Usefulness of letters form hospitals to general practitioners. $\mathrm{Br}$ Med J 1984;288:1813-1814.

10. Branger PJ, Wouden van der JC, Duisterhout JS, Lei van der J. Problems in communication between general practitioners and internal medicine consultants. Med Inform 1995;20:45-51.

11. Penney TM. Delayed communication between hospitals and general practitioner: where does the problem lie? Br Med J 1988;297:28-29.

12. Wouden van der JC, Dokter HJ. Samenwerking tussen huisarts en specialist bij patiënten met kanker (Collaboration between GP and specialist in patients with cancer, in Dutch). Huisarts Wet 1989;32:51-55.

13. Ong LM, de Haes JC, Hoos AM, Lammes FB. Doctor-patients communication: a review of the literature. Soc Sci Med 1995;40:903-918.

14. Stewart MA. Effective physician-patient communication and health outcomes: a review. Can Med Assoc J 1995;152:1423-1433. 



\section{CHAPTER 6}

\section{Effects of electronic communication on the communication between surgeon and general practitioner for patients suspected of breast cancer: A randomised clinical trial}

Submitted for publication

W.J. van der Kam ${ }^{1.2}$, B. Meyboom-de Jong ${ }^{3}$, P. Spoelstra, J.E. de Vries', E.G.J.M. Pierik', E. Nijland ${ }^{3}$, H.E.P. Bosveld, M.C.J.M. Sturkenboom ${ }^{2}$, J. van der Lei ${ }^{2}$

'Isala Clinics, Zwolle, The Netherlands

${ }^{2}$ Dept. of Medical Informatics, Faculty of Medicine and Health Sciences, Erasmus University, Rotterdam, The Netherlands

${ }^{3}$ Dept. of General Practice, University of Groningen, Groningen, The Netherlands

${ }^{4}$ General practitioner, Zwolle, The Netherlands 



\section{Summary}

Introduction: Continuity of care for patients suspected of having breast cancer requires communication between the first and second line. Although national and regional guide lines exist about this kind of communication, experience has taught that the execution of guidelines thereof is not self evident. Electronic communication can be a guideline for the implementation of guidelines regarding communication.

Objective: In the treatment of patients suspected of having breast cancer, we studied the effects of electronic communication on (a) the speed, (b) the content of communication, and (c) the quality of life of the patient.

Set-up: A randomised study by which 38 general practitioners (20 practices) were randomised in a control group and an intervention group. Physicians in the intervention group were provided with electronic communication. Patients who were referred to a surgeon by the general practitioner on suspicion of having breast cancer were included.

Results: In total, 145 patients were included. There were no differences between the groups as regards compliance with national agreements. Physicians who communicated electronically followed regional appointments better. The speed of communication was higher in the group using electronic communication. Electronic communication did not have an effect on the quality of life of the patient.

Conclusion: We conclude that electronic communication can have an added value in relation to the communication round a specific patients' category.

Keywords: $\quad$ Electronic communication; General practitioner; Breast cancer; Family practice

\section{Introduction}

More and more physicians are involved in the care for an individual patient [1]. Scientists report that when different physicians are involved in the care, communication between physicians is important to guarantee an optimal follow-up and treatment of the patient [2-4].

Both the general practitioner and the specialist are involved in the follow-up and treatment of women suspected of having breast cancer. In former studies, we studied the communication between physicians for patients that were suspected of having breast cancer $[5,6]$. We concluded that the patient was seen by various physicians, but that these physicians did not inform each other adequately $[5,6]$. Adequate communication presupposes agreements between the various physicians about the content and timing of communication [7,8]. In The Netherlands, when referring a patient, the general practitioner usually writes a letter to the specialist 
with the tentative diagnosis and the clinical presentation of the question. The specialist informs the general practitioner about the course of the diagnostic and treatment of the patient in second line by means of the outpatient letter and the discharge letter. Although there are numerous guidelines available in The Netherlands for both the general practitioner [9] and the specialist [10], there exist only a few general agreements about the transmural communication for specific patients' groups. The NHG formulated a number of general minimum requirements for a referral letter of the general practitioner to the specialist [11]; and a number of specialists formulated minimum requirements for the outpatient letter and the discharge letter [12-14]. The consequence hereof is that on a regional level often additional agreements and guidelines are made about the communication.

Experience with guidelines, however, teaches us that even if the physicians themselves were involved in creating guidelines, it does not mean that the execution thereof is self evident [15-18]. Electronic communication can facilitate the implementation of guidelines with regard to communication [18].

Evaluation studies of the effects of electronic communication are only scarcely available; a single study reports faster communication $[3,19,20]$ and less errors in the general practitioner file because the results of laboratory measurements were no longer put into the system by hand [19]. As far as we know, there is not a single randomised trial available whereby the effects of electronic communication are studied.

In a randomised study we examined the effects of electronic communication in the treatment of patients suspected of having breast cancer. The study consisted of two phases. In the first phase, the communication between the general practitioner and the surgeon was outlined. Based on the findings of this first phase, additional regional guidelines about the communication were made. In the second phase, the group of participating general practitioners was divided at random into two groups by which one group was going to use electronic communication, and the other group was going to continue to communicate in the usual way. In addition, we examined the effects on the patient himself.

\section{Method}

\subsection{Intervention}

We developed a communication system that enabled the surgeon and the general practitioner to send and receive electronic messages among themselves with the aid of Edifact messages.

For the general practitioner the communication system was integrated with the electronic medical file. The general practitioner is able to make a referral letter in the communication system by selecting parts of the electronic medical file and then add free text. The communication system then asks for the name of the 62 
receiver (the specialist) and sends the message. The general practitioner is not obliged to make use of the communication system in order to make a referral letter; communication by means of paper remains possible.

For the surgeon the communication system was installed on the computer at the outpatients' clinic department. The surgeon is able to make an outpatient letter and a discharge letter by selecting parts of the electronic referral letter from the general practitioner and then add free text. The communication system then asks the name of the receiver (the general practitioner) and sends the communication. The surgeon is not obliged to use the communication system; communication by means of paper remains possible.

Each of the general practitioners and surgeons must check daily whether any electronic messages have arrived for him or her in the electronic mailbox system.

\subsection{Participants}

In the cities of Zwolle and Kampen, we asked the 54 general practitioners (in 36 practices) that were using an electronic medical file (ELIAS R) in November 1996 to participate in the study. In total, 48 general practitioners from 30 practices agreed to participate in the survey.

The general practitioners predominantly referred to the Sophia hospital and the hospital De Weezenlanden in the city of Zwolle. In these hospitals, three surgeons have been applying themselves particularly to patients suspected of having breast cancer; we asked these three surgeons to participate in the study, and all agreed to do so.

\subsection{Randomisation}

In the first phase, the departure situation was determined for the entire group of general practitioners and surgeons. During this first phase, 10 general practitioners notified us that they did not wish to continue participating in the study. Five general practitioners considered it too great an emotional burden for the patient; four general practitioners thought that the study took too much time; and one general practitioner became ill for a long period of time. The remaining 38 general practitioners ( 20 practices) of the premeasured group finished the first phase of the study and were afterwards put, at random, either into the intervention group which communicated electronically, or the control group which only had the disposal over the paper version of the guidelines for communication. We randomised on the practice's level to avoid spilling. It implied a stratified randomisation (solo practices, dual practices and group practices). Each practice was assigned at random by an independent researcher to the intervention- or the control group. After the randomisation, 10 practices ( 17 general practitioners) had been enclosed in the control group and 10 practices ( 21 general practicioners) in the intervention group. 


\subsection{Patients and protocol}

The first phase of the study, determining the premeasurement, took place from 1 January 1997-15 May 1998. The general practitioners asked a written permission (informed consent) of all patients that were suspected of having breast cancer and were referred to the surgeon. The patient was then given a referral letter for the surgeon. The patient also received a questionnaire with the request to complete it the evening before the first visit to the surgeon at the outpatients' clinic. The questionnaire contained questions with regard to the quality of life and the state of mind of the patient.

After the first visit to the outpatients' clinic, the surgeon sent a letter, the first outpatient letter, to the general practitioner about his findings and conclusions. If the patient was admitted for surgery (mastectomy or a mamma conserving surgery), the surgeon sent a definite discharge letter to the general practitioner about the course.

After rounding off the diagnostic and possible surgery, we again sent the patients the questionnaire with respect to the quality of life and the state of mind of the patient. The admitted patients received this second list 12 weeks after the surgery date, and the outpatients 14 weeks after the initial referral.

We discussed the results of the first phase, the premeasurement, with the participating physicians. In addition, the available national guidelines on transmural communication were analysed. Based on these discussions, the participating physicians formulated in addition to the national guidelines a number of regional guidelines about the content of the referral letter, the first outpatient letter, and the discharge letter. The physicians indicated that the communication clearly fell short in two areas. Firstly, the information about the psycho-social condition of the patient was lacking; secondly, with respect to the information provided to the patient; it was not always clear to the recipient of a message exactly which information had already been given to the patient. Especially in those cases where the patient had been diagnosed with a malignant carcinoma, it was not always evident to the general practitioner to what extent and detail the patient had been informed by the specialist beforehand about the course of the disease. These regional guidelines were made available to all physicians.

The second phase of the study consisted of the intervention and took place from 1 June 1998-December 1999.

The electronic communication system was installed for the intervention group. The physicians received a short oral- and a written instruction about the use of the software. For a period of 2 weeks messages about testpatients were exchanged in order to become familiar with the communication system. Both the control and the intervention group were informed in writing at the start of the second phase about the national and regional agreements. 


\subsection{Outcomes between the general practitioner and the surgeon}

The outcomes have been divided into three groups: the content of the communication, the speed of the communication, and the quality of life.

\subsection{Content of the communication}

The medical files of the surgeon and the general physician were studied by us to judge the content of the communication. For the admitted patients we studied the files 12 weeks after the surgery date. For the outpatients we studied the files 14 weeks after the initial referral.

At the surgeon and the general practitioner, we checked whether there was a referral letter available of the general practitioner. The content of the referral letter was judged by two persons independently of each other. If these two persons disagreed with each other, the opinion of a third person was asked. The opinion of this third person then was the decisive factor. For each referral letter, we counted the number of relevant items in accordance with the guidelines of the Dutch College of General Practitioners (NHG) [9]. In addition, we analysed whether the referral letter contained psycho-social information. Finally, we analysed whether the referral letter described the kind of information that had been given to the patient.

At the general practitioner and the surgeon, we looked whether there was a first outpatient letter available from the surgeon. The content of the outpatient letter was judged by two persons, independently of each other. If these two persons disagreed with each other, the opinion of a third person was asked. The opinion of this third person then was the decisive factor. For each first outpatient letter, we counted the number of relevant items in accordance with the guidelines of Verhaage-Spliet and Kersten [12]. We also analysed whether the first outpatient letter contained psycho-social information. Finally, we analysed whether the first outpatient letter described the information that had been given to the patient.

For the patients that were admitted for surgery (mastectomy or mamma-conserving surgery), we checked with the general practitioner and the surgeon whether there was a definitive discharge letter available from the surgeon. The content of the discharge letter was judged by two persons independently of each other. If these two persons disagreed with each other, the opinion of a third person was asked. The opinion of this third person then was the decisive factor.

For each discharge letter, we counted the number of relevant items in compliance with the guidelines of van Beusekom and Geerling [14]. We also analysed whether the discharge letter contained psycho-social information. Finally, we analysed whether the discharge letter contained the information given to the patient.

In the intervention group, we analysed for each referral letter, first outpatient letter, and discharge, whether this communication had taken place electronically. 


\subsection{The speed of communication between the general practitioner and the surgeon}

We determined the time in days between the writing of the referral letter by the general practitioner and the date of the first consultation of the patient with the surgeon. Then we determined the time in days between the date of the first consultation with the surgeon and the date of the first

outpatient letter. Finally, we determined the time in days for the admitted patients between the patient's discharge from the hospital and the date of the discharge letter.

\subsection{Quality of life of patients}

The patient completed four questionnaires on the evening before the first visit to the surgeon at the outpatients' clinic. The admitted patients completed the same questionnaires 12 weeks after the date of surgery. The outpatients completed the same questionnaires 14 weeks after the initial referral.

The four questionnaires were the Profile of Mood State (POMS) [21,22], the Dartmouth COOP Function Chart/WONCA (COOP/WONCA) [23], the Short Form-36 Health Survey Questionnaire (SF-36) [24,25], and the European Organisation of Research on Treatment of Cancer, Quality of Life Questionnaire C30 (EORTC-QLQ-C30, abbreviated QLQ-C30) [26,27]. With the POMS, the feelings of patients are determined; with the COOP/WONCA, the functional state of health; with the SF-36, the subjective state of health; and with the QLC-C30, the quality of life for patients with cancer. All scales are trustworthy and valid [21,24,28-33] and are applied on patients with breast cancer [34-38]. Of each questionnaire, one or more sum scores were calculated over subscales with different items when Cronbach's alpha was larger or equal to [70]. The calculated sum scores for the POMS relate to the subscales depressive ( 8 items), angry (7 items), tired ( 6 items), strong ( 6 items), and tense ( 6 items) [21]. The scale range of the POMS went from 0 (not at all applicable) to 4 (very much applicable). The scale range signifies for all scales that a high score is valued negatively, except with strength where, on the contrary, a high score is valued positively. The sum score for the COOP/WONCA functional situation was calculated over 5 items, the sixt item, change in health, was left out. The scale range of the COOP/WONCA went from 1 (best) to 5 (worst). The sum scores for the SF-36 apply to the physical state of health, calculated over 6 subscales with 27 items, and the mental state of health, calculated over 5 subscales with 19 items [24,39]. The scale range went from 0 (worst)-100 (best). The sum scores for the QLC-C30 were calculated for physical functioning ( 7 items), psycho-social functioning ( 8 items), global state of health (2 items) and symptoms (12 items). Financial difficulties were not incorporated into a sum score. The scale range was converted to a scale of 0 
(worst) to 100 (best), except for the symptoms whereby $0=$ no suffering at all from the 12 symptoms and $100=$ maximal suffering from the 12 symptoms.

\subsection{Data analysis}

We compared the characteristics of the practices and communication characteristics between the study arm by means of Chi-square statistics. Two-sided p-values below 0.05 were considered statistically significant. We asked the patient to complete questionnaires at two points in time. The first point in time, $\mathrm{T} 1$, was the day of the first consultation with the surgeon. The second point in time, T2, is for the admitted patients 12 weeks after the date of surgery, and for the outpatients 14 weeks after the initial referral. The questionnaires have not been fully completed by all patients on all points in time. To test whether there was a change in the quality of life scores, we tested whether the scores differed on T1 and T2, both for the base-line group, the intervention group and the control group between the admitted and outpatients by means of the two-tailed T-test. P-values were considered significant if they were below 0.05 . Secondly, we evaluated if there was an effect of the intervention: the electronic communication. The one-way Anova was used for this evaluation.

Thereafter we performed a repeated measures analysis of variance to assess if there were joint effects of time, and (non-)admittance. Since we found no effect of the intervention, the intervention was skipped from the analysis. For calculations we used the SPSS software package for Windows version 8.0.0.

\section{Results}

A number of the characteristics of the participating general practitioners (namely, age, gender, number of registered patients, type of practice, and duration of practice) are stated in Table 1.

During the premeasurement, 75 patients were asked by the general practitioner to participate in the study; 60 patients were willing to do so. Of these 60 patients, 31 were admitted. 36 Patients were asked by the general practitioner for the control group; 30 patients were willing to participate. Of these 30,15 were admitted. For the intervention group, 61 patients were asked, of which 55 agreed to do so, whereof 30 were admitted. The average age of the respondents (56.0 years, $\mathrm{SD}: \mathrm{SD}: 17.0$ ) did not differ significantly from the average age of the nonrespondents (51.1 years, SD: 14.8$)(t$-test: $\mathrm{p}=0.14)$ at the moment that the general practitioner asked the patient to participate in the study.

Table 2 shows the presence of the referral letter, the first outpatient letter, and the definite discharge letter in the files of the general practitioner and/or surgeon. The referral letter is present in $56(93 \%)$ files at the time of the premeasurement; in 29 (88\%) files at the control group; and in 52 (95\%) files at the intervention group. Of the 52 referral letters, 39 had been sent electronically (Table 2). 
Table 1

Characters of the participating general practitioners (age, gender, number of registered patients and duration of practice)

\begin{tabular}{|c|c|c|c|c|c|}
\hline Characteristics & $\begin{array}{c}\text { Control } \\
\text { group } \\
\mathrm{n}\end{array}$ & $\%$ & $\begin{array}{c}\text { Intervention } \\
\text { group } \\
\mathrm{n}\end{array}$ & $\%$ & p-value \\
\hline \multicolumn{6}{|l|}{ Age } \\
\hline $30-34$ & 2 & 11.8 & & & \\
\hline $35-39$ & & & 3 & 14.3 & \\
\hline $40-44$ & 3 & 17.6 & 7 & 33.3 & \\
\hline $45-49$ & 7 & 41.1 & 5 & 23.8 & \\
\hline $50-54$ & 3 & 17.6 & 4 & 19.0 & \\
\hline $55-59$ & 1 & 5.9 & 1 & 4.8 & \\
\hline $60-65$ & 1 & 5.9 & 1 & 4.8 & 0.35 \\
\hline \multicolumn{6}{|l|}{ Gender } \\
\hline Malen & 16 & 94.1 & 21 & 100 & \\
\hline Female & 1 & 5.9 & 0 & & 0.45 \\
\hline \multicolumn{6}{|c|}{$\begin{array}{l}\text { Number of registered patients } \\
\text { per general practitioner }\end{array}$} \\
\hline Mean $\pm S D$ & $2499 \pm 463.49$ & & $\begin{array}{c}2606.43 \pm 227 \\
25\end{array}$ & & 0.39 \\
\hline \multicolumn{6}{|l|}{ Type of Practice } \\
\hline Solo & 5 & 29.4 & 4 & 19.0 & \\
\hline Duo & 6 & 35.2 & 6 & 28.6 & \\
\hline Group & 6 & 35.2 & 11 & 52.4 & 0.56 \\
\hline \multicolumn{6}{|l|}{ Duration of practice } \\
\hline $1-5$ years & 3 & 17.6 & 4 & 19.0 & \\
\hline 6 -10 years & I & 5.9 & 4 & 19.0 & \\
\hline 11-15 years & 5 & 29.4 & 3 & 14.3 & \\
\hline $16-20$ years & 3 & 17.6 & 4 & 19.0 & \\
\hline $21-25$ years & 4 & 23.5 & 5 & 23.8 & \\
\hline 26-30 years & 0 & & 0 & & \\
\hline$>30$ years & 1 & 5.9 & 1 & 4.8 & 0.81 \\
\hline
\end{tabular}

Table 3 shows the content of the paper letters and Edifact messages between the general practitioner and the surgeon. Of the 56 referral letters during the premeasurement, $49(88 \%)$ met the minimum requirements as formulated by the 
Table 2

The presence of the referral letter, the first outpatient letter, and the definitive discharge letter.

\begin{tabular}{|c|c|c|c|c|}
\hline & & $\begin{array}{l}\text { Baseline } \\
\text { group }\end{array}$ & $\begin{array}{l}\text { Control } \\
\text { group }\end{array}$ & $\begin{array}{l}\text { Intervention } \\
\text { group }\end{array}$ \\
\hline & Number of patients & 60 & 33 & 55 \\
\hline \multirow[t]{2}{*}{ Referral letter } & Paper letter & $56(93 \%)$ & $29(88 \%)$ & $52(95 \%)$ \\
\hline & $\begin{array}{l}\text { As paper copy of an } \\
\text { electronic message }\end{array}$ & 0 & 0 & 39 \\
\hline \multirow[t]{3}{*}{ First outpatient letter } & Paper letter & $49(82 \%)$ & $29(88 \%)$ & $52(95 \%)^{\wedge}$ \\
\hline & $\begin{array}{l}\text { As paper copy of an } \\
\text { electronic message }\end{array}$ & & & 30 \\
\hline & $\begin{array}{l}\text { Number of admitted } \\
\text { patients }\end{array}$ & $31(52 \%)$ & $15(46 \%)$ & $30(55 \%)$ \\
\hline \multirow[t]{2}{*}{ Definitive discharge letter } & Paper letter & $15(48 \%) *$ & $11(73 \%) *$ & $23(77 \%) *^{*}$ \\
\hline & $\begin{array}{l}\text { As paper copy of an } \\
\text { electronic message }\end{array}$ & 0 & 0 & 3 \\
\hline
\end{tabular}

* Percentage of admitted patients.

$" p=0.035$ for the comparison between the baseline group and the intervention group.

${ }^{\mathrm{p}} \mathrm{p}=0.023$ for the comparison between the baseline group and the intervention group.

Dutch College of General Practitioners; in the control group, 27 of the 29 (93\%) referral letters sufficed; and in the intervention group 48 out of the $52(92 \%)$.

Table 4 shows the time in days between the date of the referral letter, the first consultation of the patient with the surgeon, and the date of the first outpatient letter of the surgeon; and also the time between the date of the discharge of the patient and the date of the discharge letter. The average time between the date of the referral letter and the date of the first consultation in the premeasurement is 3.5 days $(n=56$, median 2 days, $\mathrm{SD} 3.5$ ); in the control group 5.2 days $(\mathrm{n}=29$, median 3 days, $\mathrm{SD}$ 7.4); and in the intervention group 4 days ( $n=52$, median 3 days, SD 3.9).

Table 5 shows the Quality of Life scores at two points in time. The first point in time, $\mathrm{T} 1$, is the day that the first consultation with the surgeon took place. The second point in time, $\mathrm{T} 2$, is for the admitted patients 12 weeks after the surgery date, and for the outpatients 14 weeks after the initial referral. At the start of the study on T1, it appears that there are no significant differences in quality of life scores between the premeasurement-, the intervention- and the control group. Of the intervention, that is the electronic communication, only insignificant effects were found between the groups at T2, which are not recorded in Table 5. 
Table 3

The content of communication between surgeon and general practitioner

\begin{tabular}{|c|c|c|c|}
\hline & $\begin{array}{l}\text { Baseline } \\
\text { group }\end{array}$ & $\begin{array}{l}\text { Control } \\
\text { group }\end{array}$ & $\begin{array}{l}\text { Intervention } \\
\text { group }\end{array}$ \\
\hline Number of referral letters or messages & 56 & 29 & 52 \\
\hline \multicolumn{4}{|l|}{ National guidelines (NHG): } \\
\hline Alle minimum requirements present $(\%)$ & $49(88 \%)$ & $27(93 \%)$ & $48(92 \%)$ \\
\hline Other relevant items present $(\%)(\max =8)$ & $53(95 \%)$ & $28(97 \%)$ & $50(96 \%)$ \\
\hline Mean number of items & 3.1 & 2.6 & 2.9 \\
\hline Median number of items & 3 & 2 & 3 \\
\hline \multicolumn{4}{|l|}{ Regional guidelines: } \\
\hline Psychosocial information present $(\%)$ & $6(11 \%)$ & $4(14 \%)$ & $20(39 \%)^{A .13}$ \\
\hline $\begin{array}{l}\text { Details about Information provided to the patient } \\
\text { present }(\%)\end{array}$ & $5(9 \%)$ & $2(7 \%)$ & $36(69 \%)^{C .1 D}$ \\
\hline Number of first outpatient letters or messages & 49 & 29 & 52 \\
\hline \multicolumn{4}{|l|}{ National guidelines (Verhaage Spliet): } \\
\hline Relevant items present $(\%)(\max =9)$ & $46(96 \%)$ & $29(100 \%)$ & $52(100 \%)$ \\
\hline Mean number of items & 6.0 & 5.24 & 5.31 \\
\hline Median number of items & 6 & 5 & 5 \\
\hline \multicolumn{4}{|l|}{ Regional guidelines: } \\
\hline Psychosocial information present $(\%)$ & $2(4 \%)$ & $2(7 \%)$ & $8(15 \%)^{\mathrm{E}}$ \\
\hline $\begin{array}{l}\text { Details about information provided to the patient } \\
\text { present }(\%)\end{array}$ & $18(37 \%)$ & $9(31 \%)$ & $37(71 \%)^{\mathrm{F} G \mathrm{G}}$ \\
\hline Number of definitive discharge letters or messages & 15 & 11 & 23 \\
\hline \multicolumn{4}{|l|}{ National guidelines (Beusekom and Geerling ): } \\
\hline Relevant items present $(\%)(\max =10)$ & $15(100 \%)$ & $11(100 \%)$ & $23(100 \%)$ \\
\hline Mean number of items & 8.4 & 6.1 & 7.3 \\
\hline Median number of items & 9 & 6 & 7 \\
\hline \multicolumn{4}{|l|}{ Regional guidelines: } \\
\hline Psychosocial information present $(\%)$ & $2(13 \%)$ & $0(0 \%)$ & $3(13.0 \%)$ \\
\hline $\begin{array}{l}\text { Details about information provided to the patient } \\
\text { present }(\%)\end{array}$ & $4(27 \%)$ & $3(27 \%)$ & $5(26 \%)$ \\
\hline
\end{tabular}

A: $\quad p<0.001$ for the difference between the baseline group and the intervention group.

B: $\quad p=0.037$ for the difference between the intervention group and the control group.

C: $p=0.003$ for the difference between the baseline group and the intervention group.

D: $\quad p<0.001$ for the difference between the intervention group and the control group.

E: $p=0.020$ for the difference between the baseline group and the intervention group.

F: $\quad p<0.001$ for the difference between the baseline group and the intervention group.

$\mathrm{G}$ : $\quad \mathrm{p}=0.001$ for the difference between the intervention group and the control group. 
Table 4

The time in days between the date of the referral letter, the first consultation of the patient with the surgeon, and the date of the first outpatient letter of the surgeon, and next to it the date of the dismissal of the patient and the date of the discharge letter.

\begin{tabular}{|c|c|c|c|}
\hline Time in days between: & $\begin{array}{l}\text { Baseline } \\
\text { group }\end{array}$ & $\begin{array}{l}\text { Control } \\
\text { group }\end{array}$ & $\begin{array}{l}\text { Intervention } \\
\text { group }\end{array}$ \\
\hline $\begin{array}{l}\text { Date of referal letter and date of } 1 \text { st } \\
\text { consultation surgeon }\end{array}$ & $n=56$ & $\mathrm{n}=29$ & $n=52$ \\
\hline mean & 3.5 & 5.2 & 4.0 \\
\hline median & 2 & 3 & 3 \\
\hline $\mathrm{SD}$ & 3.5 & 7.4 & 3.9 \\
\hline $\begin{array}{l}\text { Date of } 1 \text { st consultation surgeon } \\
\text { and date of } 1 \text { st outpatient letter }\end{array}$ & $n=49$ & $n=29$ & $\mathrm{n}=52$ \\
\hline mean & 11.9 & $12.1^{\mathrm{A}}$ & 9.2 \\
\hline median & 8 & 7.9 & 7 \\
\hline SD & 11.2 & 10 & 9.5 \\
\hline $\begin{array}{l}\text { Date discharge of patient and date } \\
\text { of definitive discharge letter }\end{array}$ & $n=15$ & $n=11$ & $n=23$ \\
\hline mean & 13.1 & 23.8 & 13.7 \\
\hline median & 10 & 20 & 14 \\
\hline $\mathrm{SD}$ & 12.4 & 16.9 & 8.6 \\
\hline
\end{tabular}

A: $\mathrm{p}=0.027$ (Mann-Whitney $U$-test) for the difference in time between the intervention group and the control group.

Table 6 shows the results of the repeated measures' analysis of variance. The repeated measures' analysis did not show either significant differences in quality of life scores between the premeasured-, the intervention- and the control group. These insignificant effects are not recorded in Table 6 and Figure 1.

It appears that only of the variable time a major effect is seen with the sumscores of the POMS scales powerful and tense; with the physical health condition, measured with SF-36 and QLC-C30; and with the number of symptoms when considering the entire group of both admitted- and outpatients as a whole. With respect to tiredness, state of health, and symptoms, it appears that there is a significant interaction effect of time and of having been admitted, or not. Figure 1 shows that the tiredness of outpatients remains the same, whereas the tiredness of admitted patients increases; the sense of strength increases slightly both for outpatients and admitted patients, but a little less for the admitted patients. The tension of both outpatients as admitted patients decreases. The state of health, 


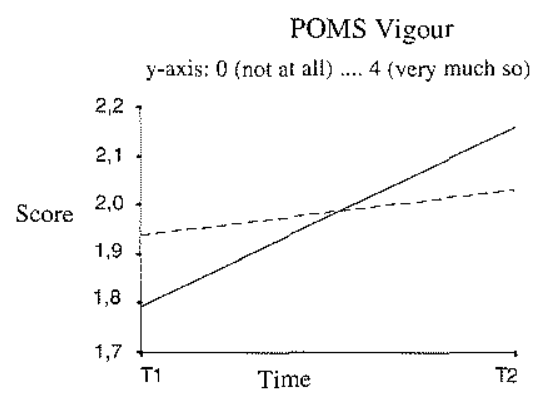

POMS Fatigue

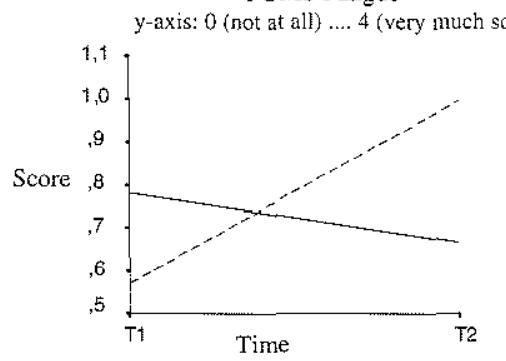

SF-36 physical state of health y-axis: 0 (worst) .... 100 (best)

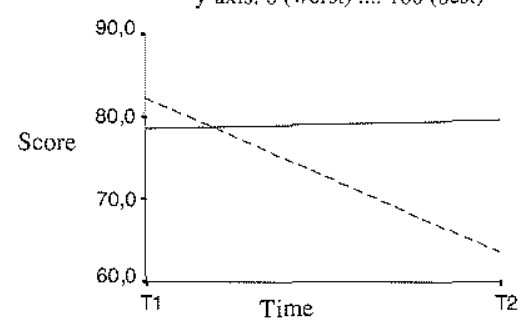

QLQ-C30 physical functioning y-axis: 0 (worst) .... 100 (best)

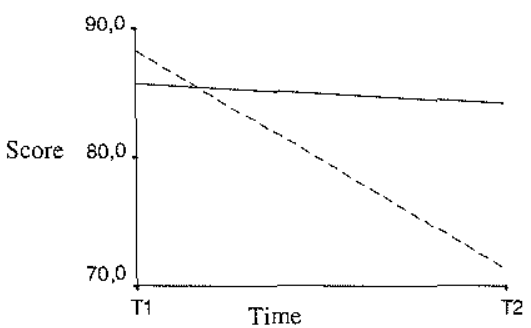

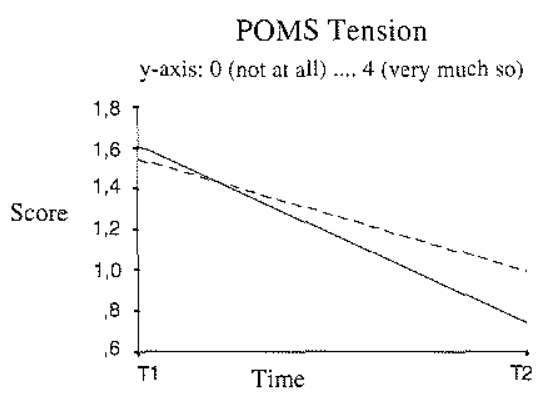

COOP-WONCA

y-axis: 0 (no limitation) .... 5 (severely limited)
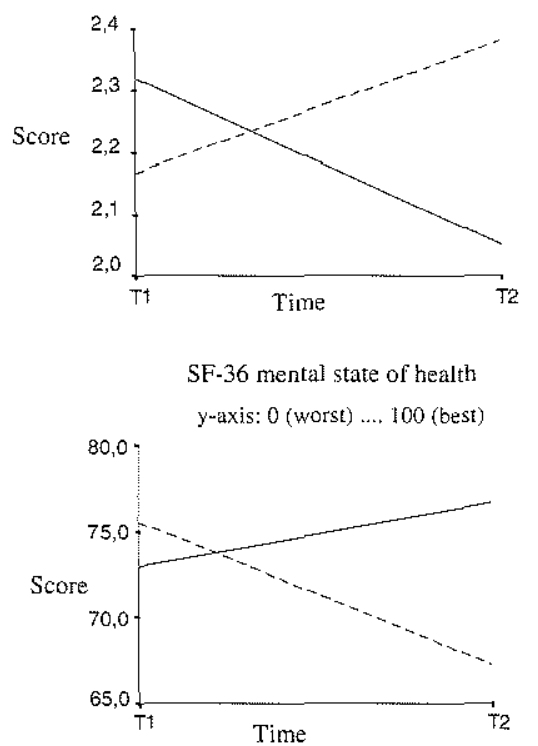

QLQ-C30 symptoms

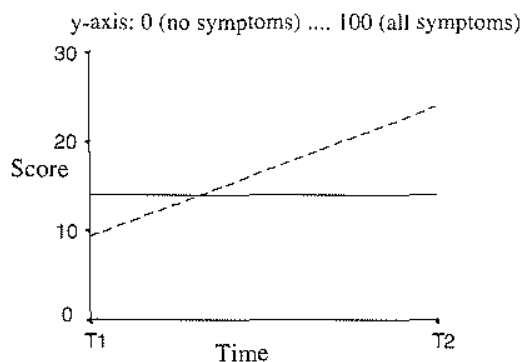

Figure 1. Main effect time and main effect admitted of 8 sumscores of Table 6 . Top 2 sumscores with only a main effect time and below 6 sumscores with significant interactions. Solid line $=$ admitted patients, dashed line $=$ outpatients. 
Tabel 6

The repeated measures analyses of variances

\begin{tabular}{lllll}
\hline Scale & Sumscore & $\begin{array}{l}\text { Main } \\
\text { effect } \\
\text { time }\end{array}$ & $\begin{array}{l}\text { Main } \\
\text { effect } \\
\text { admitted }\end{array}$ & Interaction \\
\hline POMS & $\begin{array}{l}\text { Depressive } \\
\text { Angry }\end{array}$ & & \\
& Fatigue & & 0.01 \\
& Vigour & 0.05 & \\
Tension & 0.000 & 0.000 \\
COOP-WONCA & Physical sum & 0.000 & 0.000 \\
SF-36 & Mental sum & & 0.001 \\
QLQ-C30 & $\begin{array}{l}\text { Physical funct. } \\
\text { Global health }\end{array}$ & 0.000 & 0.000 \\
& Symptoms & 0.000 & 0.000 \\
& Psy-soc funct. & & \\
& Financial & & \\
& & & \\
\hline
\end{tabular}

measured with the COOP/WONCA, the SF-36, and the QLC-C30, remains globally the same for the outpatients and declines for the admitted patients. The scales of the state of health determined with COOP/WONCA- cards on the one hand and the SF-36 and the QLQ-C30 on the other hand have an opposite course. For that reason, the decline on the COOP/WONCA is indicated by a rising line and on the SF-36 and the QLQ-C30 by a falling line. Also the mental state of health measured with the SF-36 indicated a decline for the admitted patients. The symptoms increased for the admitted patients.

\section{Discussion}

Quality in care requires adequate communication between the care providers that are involved in that care [2-4]. In our study, we studied the guidelines with respect to the communication round the patients that were suspected of having breast cancer, and who were referred to a surgeon by a general practitioner. The purpose of our randomised study was to investigate whether electronic communication between general practitioners and surgeons influenced the implementation of guidelines with regard to the communication and with regard to the patient himself.

We conclude that the implementation of regional guidelines with regard to the communication round patients being suspected of having breast cancer runs smoother when the general practitioner and the surgeon communicate electronical- 
ly with one another. The presence of psycho-social information about the patient and of information which the patient had received from the physician in attendance scored significantly better in the referral letter and in the first outpatient letter in the intervention group than in the control group and the group in the premeasurement. Other researchers also have shown that psycho-social information and information to the patient score low in the paper messages between specialists and general practitioners $[7,40]$.

The regional guidelines in the discharge letter did not score better in the intervention group compared with other groups. A possible explanation therefore could be that in the intervention group only four discharge letters have been sent electronically.

Our second conclusion is that the availability of electronic communication for both the general practitioner and the surgeon does not lead to a complete replacement of paper, notwithstanding extensive instructions, test versions, and a trial period. Possible causes for same are that one is still able to make use of the customary paper communication, the low frequency of patients eligible for electronic communication, and the fact that a definitive discharge letter often was composed by other physicians, such as trainee surgeons.

In our study, electronic communication had a significant influence on the time between the date of the first consultation of the surgeon and the date of the fist outpatient letter between the control group and the intervention group. This is in line with other researchers who report that electronic communication leads to an increase in the speed of communication [23,19,41,42].

The Quality of Life was measured twice for the same patient: the day before the first visit to the surgeon and 12-14 weeks later. At the start of the study, the quality of life as measured by us was similar in the different groups. As regards the intervention, that is the electronic communication, no significant differences were seen. That gives rise to the question whether with these quality of life scores, differences can be measured at all. Therefore, we investigated whether differences that could be expected on T1 and T2 between admitted-and outpatients could be determined. In the outpatients, that did not have breast cancer, we see that with respect to the tiredness nothing changes; in the admitted patients that had cancer and had been treated for it, the tiredness appeared to increase. The tension decreased in both groups, more in the outpatients. In the admitted patients, we saw a clear decline of the physical and mental state of health and an increase in symptoms, while those aspects hardly changed in the outpatients. These findings are conform the literature [34-38] and fit the course of the syndrome.

Comparison of the control group and the intervention group, however, shows that the intervention is neither associated with positive- nor with negative influences on the state of mind and the quality of life of patients. A possible explanation is that the state of mind and the quality of life of patients can be influenced by many separate variables in the diagnostic phase of breast cancer so that influencing by 
the regional guidelines as such cannot be observed [34-36]. Moreover, the intervention, that is the electronic communication, was used by general practitioners and surgeons who started working with it relatively recently. Maybe, the communication pattern will change measurably at the time that practitioners are used from the beginning to communicate electronically, also with and about their patients.

Our study consists of a relatively small number of patients of a specific category so that we have to be careful to generalise our conclusions for a large group. Further research with larger groups of patients is necessary to evaluate electronic communication between care providers on a large scale.

Summarising, our conclusion is that electronic communication can have an added value for the implementation of guidelines with regard to the communication round a specific patients' category. In addition, electronic communication turns out to lead to a faster way of giving information. Other effects on communication behaviour between the general practitioner and the surgeon were not measured by us. Should we want to effectuate the often talked-about but little-evaluated effects of electronic communication [43], it is our conviction that fundamental agreements have to be made about the method of working procedure, cooperation and communication between care providers. It will then be possible to evaluate electronic communication as part of more extensive changes within the primary process. 


\section{References}

1. Branger PJ. Clinicians at work: Sharing Care in the Information Age. Yearbook Medical Informatics 1997:83-91.

2. Branger PJ, Duisterhout JS. Communication in Health Care. Methods Inf Med 1995;34:244-252.

3. Hasman A, Ament A, Arnou PC, van Kesteren ACA. Inter-institutional information exchange in healthcare. Int J Biomed Comput 1992;31:5-16.

4. Van der Wouden JC, Dokter HJ. Samenwerking tussen huisarts en specialist bij patienten met kanker (Collaboration between GP and specialist in patients with cancer, in Dutch). Huisarts Wet 1989;32:51-55.

5. Van der Kam WJ, Branger PJ, van Bemmel JH, Meyboom-de Jong B. Communication between physicians and with patients suffering from breast cancer. Fam Pract 1998;15:415-419.

6. Van der Kam WJ, Meyboom -de Jong B, Moorman PW, van der Lei J, Duitgenius J, van der Wouden JC. Communication among physicians when treating patients with suspected breast cancer. Cancer Strategy 2000;2:31-34.

7. Hampson JP, Roberts RI, Morgan DA. Shared care: a review of the literature. Fam Pract 1996;13:264-279.

8. Wood ML. Communication between cancer specialists and family doctors. Can Fam Physician 1993;39:49-57.

9. NHG standaarden. Richtlijnen voor het handelen en de praktijkvoering van de huisarts. 1989-2000.

10. TNM Systeem mammacarcinoom, UICC. 1997.

11. De verwijsbrief naar de tweede lijn; standaard $O 01$ van het Nederlands Huisartsen Genootschap (Dutch College of General Practitioners). Huisarts Wet 1989;32:541544.

12. Verhage- Spliet CMT, T. KTJJM. De inhoud van verwijsbrieven en specialistenbrieven. Huisarts Wetenschap 1990;33:148-151.

13. Verhage-Spliet CMT, Touw-Otten FWMM, Eggink HD, Van Oostrum DJFM. Terugrapportage specialist naar huisarts. Evaluatie van een model voor de poliklinische berichtgeving. Huisarts Wetenschap 1993;36:64-66.

14. Van Beusekom JAH, Geerling J. De ontslagbrief. Ned Tijdschrift Geneesk 1988;132:2315-2316.

15. Lomas J, Anderson GM, Domnick-Pierre K, Vayda E, Enkin MW, Hannah WJ. Do practice guidelines guide practice? The effect of a consensus statement on the practice of physicians. N Engl J Med 1989;321:1311-1315.

16. Lomas J. Words without action? The production, dissemination and impact of consensus recommendations. Annu Rev Public Heath 1991;12:41-65.

17. Cabana MD, Rand CS, Powe NR, Wu AW, Wilson MH, Abboud PA, et al. Why don't physicians follow clinical practice guidelines? JAMA 1999;282:1458-1465.

18. Grimshaw J, Freemantle N, Wallace S, Russell I, Hurwitz B, Watt I, et al. Developing and implementing clinical practice. Quality Health Care 1995;4:55-64.

19. Branger PJ, van der Wouden JC, Schudel BR, Verboog E, Duisterhout JS, van der Lei $\mathrm{J}$, et al. Electronic communication between providers of primary and secondary care 
[see comments]. Br Med J 1992;305(6861):1068-1070.

20. Branger PJ, van't Hooft A, van der Wouden JC, Moorman PW, van Bemmel JH. Shared care for diabetes: supporting communication between primary and secondary care. Int J Med Inf 1999;53(2-3):133-142.

21. Mc Nair DM, Lorr M, F. DL. Manual for the Profile of Mood States. San Diego: Educational and Industrial Testing Service, 1971.

22. Van der Ark LA, Marburger D, Mellenbergh GJ, Vorst HCM, Wald F. De aangepaste Profile of Mood States: een handleiding en verantwoording. Nijmegen, The Netherlands: Berkhout Nijmegen b.v., 1995.

23. Van Weel C, König-Zahn C, Touw-Otten FWMM, van Duijn NP, Meyboom- de Jong B. Measuring functional health status with the COOP/WONCA Charts. A manual. Groningen, the Netherlands: World Organization of Family Doctors (WONCA). European Research Group on Health Outcomes (ERGHO). Northern Centre for Health Care Research (NCH). University of Groningen., 1995.

24. Ware JE, Snow KK, Kosinski M, Gandek B. SF-36 Health Survey: Manual and Interpretation Guide. Boston: MA: The Health Institute, New England Medical Centre, 1993.

25. Van der Zee KI, Sanderman R. Het meten van de algemene gezondheidstoestand met de Rand-36: een handleiding. Groningen, the Netherlands: Noordelijk Centrum voor Gezondheidsvraagstukken, 1993.

26. Aaronson NK. Protocol 15861: Development of a core Quality-of-Life Questionnaire for use in cancer clinical trials. Brussels: EORTC Data Centre, 1987.

27. Fayers P, Aaronsen N, Bjordal K, Sullivan M. EORTC QIQ-C30 Scoring Manual. Brussels: EORTC group on Quality of Life, 1995.

28. Cassileth BR, Lusk EJ, Brown LL, Cross P. Psychosocial status of cancer patients and next to kin: normative data from the Profile of Mood States. J Psychosoc Oncol 1985;3:99.

29. Cella DF, Tross S, Orav EJ, Holland JC, Silberfarb PM, Rafla S. Mood states of patients after the diagnosis of cancer. J Psychosoc Oncol 1989;7(1/2):45-54.

30. Guadagnoli E, Mor V. Measuring cancer patients' affect: revision and psychometric properties of the Profile of Mood States (POMS). Psychol Assess 1989;1 (2):150154.

31. Kinnersley P, Peters T, Stott N. Measuring functional health status in primary care using the COOP-WONCA charts: acceptability, range of schffes, construct validity, reliability and sensitivity to change. Br J Gen Pract 1994;44:545-549.

32. Aaronson NK, Bullinger M, Ahmedzai S. A modulair approach to qualiity of life assessment in cancer clinical trials. Recent Results Cancer Res 1988;11:231-249.

33. Aaronson NK, Ahmedzai S, Bergman B, Bullinger M, Cull A, Duez NJ, et al. The European Organization for Research and Treatment of Cancer QLQ-C30: A Qualityof-Life instrument for use in international clinical trials in oncology. $J$ of the National Cancer Institute 1993;85:365-376.

34. Levy SM, Heberman RB, Lee JR, Lippman ME, D'Angelo T. Breast conservation versus mastectomy: Distress sequelae as a function of choice. $\mathrm{J}$ Clin Oncol 1989;7:367-375.

35. Manne SL, Sabbioni M, Bovbjerg DH, Jacobsen PB, Taylor KL, Redd WH. Coping with chemotherapy for breast cancer. J Behav Med, 1994. 
36. Sneeuw KCA, Aaronson NK, Sprangers MAG, Detmar SB, Wever LDV, Schornagel $\mathrm{JH}$. Value of caregivers ratings in evaluating the quality of life of patients with cancer. J Clin Oncol 1977;15:1206-1217.

37. Bowling A. Cancers. Measuring disease. A review of disease-specific quality of life measurement scales. Buckingham: Open University Press, 1995:20-60.

38. Carlsson M, Hamrin E. Measurement of quality of life in woman with breast cancer. Development of a Life Satisfaction Questionnaire (LSQ-32) and a comparison with the EARTC QLQ-C30. Qual Life Res 1996;5:265-274.

39. Ware JE, Kosinski M, Bayliss MS, McHorney CA, Rogers WA, Raczek A. Comparison of Methods for the scoring and statistical analysis of SF-36 health profile and summary measures: summary of results from the Medical Outcomes Study. Med Care 1995;33(4 Suppl):264-279.

40. Stalhammer J, Holberg L, Svärdsudd K, Tibblin G. Written communication from specialist to general practitioners in cancer care. What are the expectations and how are they met? Scan J Prim Health Care 1998; 16:154-159.

41. Ament A, L'Ortye M. An economic evaluation in health care (3I-project). NorthHolland, 1991.

42. Branger PJ, van der Wouden JC, Duisterhout JS, van der Lei J. Problems in communication between general practitioners and internal medicine consultants. Med Inform 1995;20:45 51.

43. Van der Kam WJ, Moorman PW, Koppejan-Mulder MJ. Effects of electronic communication with GPs. Int J Med Inform 2000;60:59-70. 


\section{CHAPTER 7}

General discussion and

Recommendations 



\section{Introduction}

Researchers report that traditional paper-based communication of patient data among general practitioners and other care providers is too slow, incomplete, inefficient and erroneous. New technologies in health-care result in information systems to document medical data in primary and secondary care. Such systems offer the potential for replacing traditional, paper-based communication by electronic communication of patient data from computer to computer.

In this thesis, we investigate the communication between general practitioners and specialists. We evaluate the effects of electronic communication between general practitioners and surgeons when they treat patients suspected of breast cancer. In the area of prescribing and dispensing medication, we focus on the impact of electronic communication between general practitioners and pharmacists.

In Section 2 of this chapter, we provide the conclusions of a literature review of the effects of electronic communication in general practice. In Section 3, we turn our attention to The Netherlands and assess whether the method of communication (paper-based versus electronic) is associated with improved quality of patient data regarding medication. We will subsequently discuss, in Section 4, the speed and type of communication between general practitioners, specialists (radiologists and surgeons) and patients with breast cancer. We also focus on the problems that general practitioners report when communicating with specialists concerning patients with breast cancer. In Section 5, we discuss the effects of electronic communication between general practitioners and surgeons on the implementation of guidelines regarding communication when treating patients in the diagnostic stage of breast cancer. We also ask ourselves the question whether the quality of life, as reported by the patient, is influenced by electronic communication. Recommendations for further research are formulated in Section 6.

\section{Electronic communication in general practice}

To obtain insight into the effects of electronic communication, we reviewed the publications describing effects of structured electronic communication of patient data to and from general practitioners. We concluded that only a few studies have compared electronic with paper-based communication, and that these studies show limited effects; the only effect that is demonstrated by more than one study is the improvement of the speed of communication.

Several researchers argue that the switch from paper-based communication to electronic communication brings about more changes than just a 'paper' to 'file' conversion. The switch to electronic communication significantly alters the processes in which messages are created and handled. We suggest that the impact of electronic communication in itself, therefore, will be difficult to measure 
because electronic communication in and of itself has limited impact. The introduction of electronic communication is a complex and multi-facetted endeavour; as a result, the distinct contribution of electronic communication may be difficult to measure.

Based on the analysis of the currently available literature we conclude that, with the exception of improved speed, a positive impact of electronic communication on the quality of health care has not been demonstrated.

\section{The effect of electronic communication on the quality of patient data regarding medication}

To evaluate whether the method of communication (paper-based versus electronic) is associated with improved quality of information regarding medication, we compared five general practitioners and a local pharmacy that rely on electronic communication with five general practitioners and a local pharmacy that rely on paper-based communication. Three different data collectors independently asked the patient, the general practitioner and the pharmacist details on the current medication of the patient on the day of admission to a hospital and 10 days after discharge.

We conclude that electronic communication between the general practitioners and the community pharmacist results in a better agreement between the general practitioner and the pharmacist with respect to the current medication of the patient when compared to paper-based communication. For the drugs reported by the patient only (that is, neither the general practitioner nor the pharmacist reported that the patient was using that specific medication), no difference between the electronic and the paper-based group could be found.

Electronic communication does not eliminate the problem of dissimilar information. When general practitioners and community pharmacist share their information using electronic communication, we expected a (near) total agreement between the general practitioner and the pharmacist. The information system of the general practitioner and the pharmacist continuously exchanged messages, and all changes in one system should be reported to the other. However, only in $69 \%$ of the cases we observed agreement between general practitioner and pharmacist on the patient's drugs.

Possible reasons for disagreement between the general practitioner and the pharmacist when electronic communication is available include failure to consistently record changes (e.g., during house calls), failure to explicitly code the discontinuation of drugs (e.g., the general practitioner records changes in medication in free text), and patient non-compliance (e.g., the pharmacist recognises that the patient is not regularly filling his or her prescriptions).

Our conclusion is that that electronic communication has improved information about the current medication as reported by the general practitioner and the 
pharmacist. Electronic communication, however, is not sufficient to obtain reliable information.

\section{The communication between GPs, specialists and patients with breast cancer}

To obtain insight into the speed and type of communication between general practitioners, specialists and patients with breast cancer, we asked general practitioners from an eastern, rural region and from a western, urban region in The Netherlands to complete a questionnaire. The questionnaire referred to the general practitioner's most recent patient with a confirmed diagnosis of breast cancer; the general practitioner was asked to use the information from the medical record to answer the questionnaire.

We conclude that, in the diagnostic stage of breast cancer, the communication among general practitioners, specialists and patients varies widely. For both of the regions, however, physicians report that the communication is too slow and incomplete.

The specialists' failure to communicate on time with the general practitioner eliminates the opportunity for the general practitioner to initiate contact with the patient and to contribute the patient's care. The patient, however, often initiates contact with the general practitioner. In the absence of information from the specialist, the general practitioner often lacks sufficient information. The inadequacy of communication is further illustrated by our finding that in $23 \%$ of the cases studied, the patient herself informs the general practitioner about the final diagnosis of breast cancer.

We conclude that the general practitioner retains an active role in the patient's care although he or she had referred the patient to the specialist. That care requires information; that information, however, is often lacking.

The general practitioners were asked in a separate questionnaire to identify problems and bottlenecks in the communication with the specialist in general. The most frequently reported problems were that the communication was too slow, the communication was too infrequent, and the tasks of general practitioner and specialist were not clearly defined or harmonised.

Although the study was conducted in two different regions (rural versus urban) of The Netherlands, the results were similar.

\section{The effect of electronic communication between GP and surgeon when treating patients with suspected breast cancer}

With regard to the treatment of patients suspected of breast cancer, we looked into the effects that electronic communication had on (a) speed and (b) contents of communication, and (c) the patient's quality of life. We concluded that regional agreements were followed more closely by physicians that communicate 
electronically. These regional agreements related in particular to the presence of psychosocial information on the patient and to information that the patient had received from the attending physician. If we were to analyse the contents of the communication, it would show that physicians that use electronic communication score significantly better.

Other researches too have shown that psychosocial information and patient education score low in paper-based communication between specialists and general practitioners. We conclude that electronic communication can have added value with regard to the specific agreements and guidelines concerning the communication around a specific category of patients.

Furthermore, the speed of communication was higher in the group that used electronic communication. Especially in a serious disease such as breast cancer, which involves major psychological effects such as anxiety and depression, it is of vital importance that all physicians involved are informed quickly and fully.

However, in our study electronic communication had no influence on patient variables such as affect and quality of live.

Hence, we conclude that neither for general practitioners nor for surgeons the availability of electronic communication led to complete replacement of paper, this in spite of elaborate instructions, test versions and a trial period. Possible reasons may be that it was still feasible to send the usual paper-based communications, the low frequency of patients that qualified for electronic communication, and the fact that the final letter of discharge was often written by other physicians than the surgeons. Although the general practitioner refers to one particular surgeon, communication on the patient from the hospital will go via a network of physicians, all involved with the same patient. Consequently, having optimal electronic communication between primary and secondary care has a considerable impact on the communication processes within the hospital. In order to have optimal communication with the primary care, streamlining and simplification of the communication processes within a hospital will be necessary.

\section{Final Remarks}

For physicians, electronic communication is relatively novel; generally, the physicians are not familiar with the process yet. Moreover, frequently the information systems are not very user-friendly and not yet integrated in the healthcare system. Users will have to be trained and systems further developed and adapted to each other.

It is remarkable that the present electronic communication is all about patients without the patient being involved him/herself. Although we concluded earlier that in the diagnostic process for suspected breast cancer the patient is often the undesired messenger of bad tidings, we found that frequently the patient participates insufficiently in the communication regarding his or her own disease. In a world where E-mail and internet facilities spread like wild fire, 84 
optimal and transparent use of electronic communication by care providers and patient can be the basis for modern patient education and information. A letter of discharge will not just be written for the purpose of reporting and filing, but can be used for real communication in the network of care providers and patient. All this to realise the ultimate goal of the health care: qualitatively good health care for the patient.

\section{Recommendations}

One of the limitations of our research is its focus on primary care. The questionnaires were aimed at general practitioners. The general practitioners pointed out difficulties in communicating with specialists. The complementary question, that is, the difficulties encountered by the specialist in communicating with primary care was not addressed. As a result, this thesis presents a viewpoint primary from the general practitioner. Further research has to establish whether similar, or other, problems are encountered by the specialist when communicating with the general practitioner.

We have addressed the patient outcome from the perspective of Quality of Life. In retrospect, one may argue that this was not the optimal choice. The Quality of Life of the patient is only partly influenced by the quality of communication. If the objective is to assess the impact of electronic communication on patient outcomes, the outcomes to measure should be more closely related to the communication on care involved. For example, if one wants to evaluate the impact of electronic communication in the area of the medication used by the patient, a possible outcome parameter could be the number of allergic reaction to penicillin.

A fascinating observation in our study was that even if an information system is communication electronically (in our case, the general practitioner's system and the pharmacist's system), the agreement between the data is far from complete. In our study, we did not measure the courses of that disagreement; we only provide a number of possible explanations. All too often, however, one is confronted with the belief that if information technology is in place, the data in the systems is of high quality. This, however, ignores that human beings will develop their own methods when using information systems. The expectations of designers do not necessary predict the actual use of the system by its final users. Further research is necessary to clarify the mechanisms involved when the conflict in data from different sources (e.g., general practitioner and pharmacist) is present even when electronic communication is available.

Finally, electronic communication is a part of a redesign of process and responsibilities. We believe that. In order to evaluate the often expressed but little proven effects of electronic communication, agreement has to be reached between health-care providers about how to deliver quality care. Electronic communication can than be evaluated in the context of that agreement. 

SUMMARY 

In The Netherlands, most citizens are enrolled in the practice of a General Practitioner. When seeking advice or treatment, the patient usually contacts his or her general practitioner, who acts as a gatekeeper to the health-care system. The general practitioner may refer the patient to other specialists if deemed necessary. The specialist reports back to the general practitioner after diagnosis and/or treatment of the patient. Optimal diagnosis and treatment of the patient requires adequate communication between the general practitioner and specialists. Continuity of care depends largely on the quality and frequency of communication between the involved physicians. In the continuity of care, the general practitioner can be seen as the 'information manager'. To perform this task, the general practitioner is dependent on information provided by other workers in the healthcare system, e.g., specialists.

A large number of studies have demonstrated that traditional paper-based communication between GPs and specialists is prone to be too slow, incomplete, inefficient and erroneous. The bottlenecks in the paper-based communication among general practitioners and specialists range from unnecessary time loss, suboptimal or even incorrect treatment, duplication of diagnostic tests, and feelings of insecurity, anxiety or fear in the patient.

New technologies are emerging, resulting in operational information systems in primary and secondary care that document medical care. Such systems offer the potential for replacing traditional paper-based communication by electronic information exchange from computer to computer. In this thesis we will call the latter 'electronic communication'.

Although it is generally assumed that electronic communication has benefits, little is actually proven. In Chapter 2, we studied the effect of electronic communication in general practice as described in peer-reviewed literature. We retrieved all publications in the English language indexed in MEDLINE and having MESH terms 'Computer Communication Networks' and having either 'family practice' or 'primary health care' as MESH term, or 'GP' or 'GPs' as text word. In total 176 publications were retrieved; of these, 30 publications met the criteria. Of these 30 publications, only 5 described proven effects with objective data, and 3 described demonstrated effects with subjective data. Although the list of possible effects is long (improved speed of communication, improved content of information in medical records, improved processes for delivering care, etc.), the only effect demonstrated in more than two studies is improved speed of communication.

In the region of Zwolle, a number of general practitioners are using electronic communication to communicate with pharmacists, whereas other general practitioners rely on paper-based communication. In Chapter 3 , we studied whether electronic communication between the general practitioner and the pharmacist provides better information regarding current medication when a patient is admitted to the hospital when compared to paper-based communication. Five general practitioners and a local 
pharmacy that rely on electronic communication were compared to five general practitioners and a local pharmacy that rely on paper-based communication. On the day of admission and 10 days after discharge, three different data collectors independently asked the patient, the general practitioner and the pharmacist, respectively, details on the current medication of the patient. We calculated the number of/ and agreement about drugs coded by the Anatomical Therapeutic Chemical (ATC) classification. A total of 139 patients were included on the first day of their admission, and 116 on the tenth day after discharge. Of the 275 drugs that were reported by the patient and/or the general practitioner and/or the pharmacist on admission in the electronic group, 134 $(49 \%)$ were reported by all parties (that is, patient and general practitioner and pharmacist), and 79 (29\%) were not reported by the patient. For the paper-based group, these figures were 340 drugs on admission, of which $107(31 \%)$ were reported by all parties, and $130(38 \%)$ were not reported by the patient.

We conclude that electronic communication between the GP and the community pharmacist results in a better agreement between the general practitioner and the pharmacist with respect to the current medication of the patient than the paperbased communication. However, electronic communication does not suffice as a solution to obtain reliable information.

Patients suffering from cancer need unambiguous advice and information about various aspects of their disease. Different physicians, including GPs, radiologists and surgeons see patients with cancer. Little is known, however, about the speed and type of communication and the problems experienced by physicians and patients. In Chapter 4, we studied the speed and type of communication between, specialists and patients with breast cancer. In addition, we questioned the general practitioner about the problems encountered in the communication with specialists concerning these patients. Two hundred and forty-six Dutch GPs from the Zwolle region were asked to complete a questionnaire based on the most recent patient in their practice with a confirmed diagnosis of breast cancer. Valid replies were received from $150(61 \%) \mathrm{GPs}$. The median period between initial referral date and receipt of the definite diagnosis from the surgeon was 4 weeks. After the patient's first appointment with the surgeon, the GPs received reports for $24 \%$ of the patients within 3 days; for 31\% 3-7 days; and for 16\% of the patients after more than 2 weeks. After the first consultation between patient and surgeon, $68(45 \%)$ of the 150 GPs reported that the patient contacted them; at this stage only $30(20 \%)$ of these GPs had received any report from the surgeon. GPs stated that the communication on patients with breast cancer is too slow (49\%), or not frequent enough (25\%); $25 \%$ of GPs found that the distribution of tasks between them and the specialists are not well described. Our conclusion is that in the diagnostic stage of breast cancer the communication between GPs, specialists and patients varies widely is too slow, and incomplete. An effect of this unsatisfactory communication is that the patient herself is the messenger of the bad news. 
The study described in Chapter 4 was limited to one region in The Netherlands. The conclusion that the communication between general practitioners and specialists is inadequate cannot be generalised to The Netherlands a whole based on this study alone. In Chapter 5, we studied whether the problems in communication between general practitioners and specialist also exist in other regions of the country. We repeated the study described in Chapter 4 in a different region: an urban setting in the western part of the country. Again we studied the speed and type of communication between, specialists and patients with breast cancer, and the problems that general practitioners encounter in the communication with specialists. A random sample of 235 of the 1200 General Practitioners was asked to complete a paper mail questionnaire in an urban region in The Netherlands. A total of $126(54 \%)$ valid replies were received from the 235 general practitioners. The average time between referring the patient to the specialist and receiving the report final diagnosis was 35 days. After receiving reports from the surgeon, $70 \%$ of the general practitioners took the initiative to contact the patient. In $30(23 \%)$ cases, the patient was the first to inform the general practitioner about the final diagnosis. The general practitioners stated that the communication from the specialist is too slow (39\%) or not frequent enough $(29 \%)$.

We conclude that communication in the diagnostic stage of breast cancer between general practitioners, specialists and patients is similar in both regions and requires improvement.

The question remains whether electronic communication is able to improve the communication between different health-care providers. In Chapter 6 , we describe a randomised study. In this study we evaluated the effects of electronic communication on speed of communication, contents of the communication, and on the quality of life in the treatment of patients suspected of breast cancer. The base-line group included 38 general practitioners (20 surgeries). After randomisation, 10 surgeries ( 17 general practitioners) were included in the control group and 10 practitioners (21 general practitioners) in the intervention group. Sixty patients were prepared to participate in the base-line group, 30 in the control group, and 55 in the intervention group. In $11 \%$ of cases information on patient education was available in the letter of referral of the base-line, in $14 \%$ in the control group, and in $39 \%$ in the intervention group. For information on patient education the percentages were $9 \%, 7 \%$ and $69 \%$.

Information on patient education was present in the first letter from the outpatient clinic in $4 \%$ of the base-line group, in $7 \%$ of the control group, and in $15 \%$ of the intervention group. For information on patient education the percentages were $37 \%, 31 \%$ and $71 \%$. In our study, the influence of electronic information on the time between the first consultation of the surgeon and the date of the first letter from the outpatient clinic was significant between the control group and the intervention group. 
We conclude that electronic communication may have added value for the implementation of guidelines concerning the communication around a certain category of patients. Other effects on the manner in which general practitioner and surgeon communicate and on the patient him- or herself were not evaluated by us. 
SAMENVATTING 

In Nederland zijn de meeste inwoners inschreven als patiënt in een huisartsenpraktijk. Voor advies en behandeling neemt de patiënt contact op met zijn of haar huisarts. De huisarts functioneert hierbij als een poortwachter in de gezondheidszorg waarbij de huisarts zo nodig de patiënt verwijst naar andere specialisten. De specialist rapporteert na het stellen van de diagnose en/of de behandeling van de patiënt terug naar de huisarts. Optimale diagnostiek en behandeling vereist adequate communicatie tussen huisarts en specialist. Continuitteit van zorg is in belangrijke mate afhankelijk van de kwaliteit en de frequentie van de communicatie van betrokken artsen in die zorg. In de continuiteit van zorg is de huisarts te beschouwen als een 'informatie manager'. On deze functie goed uit te voeren is de huisarts afhankelijk van informatie van andere werkers in de gezondheidszorg zoals bijvoorbeeld specialisten.

Veel onderzoeken hebben aangetoond dat de traditionele papieren communicatie tussen huisartsen en specialisten te langzaam, niet compleet, inefficiënt en onjuist kan zijn. De knelpunten in de papieren communicatie tussen huisartsen en specialisten zijn onnodig tijdverlies, niet optimale of zelfs onjuiste behandeling, dubbel uitgevoerde bepalingen in de diagnostiek en onzekerheid of angst bij de patiënt.

Nieuwe opkomende technologieën resulteren in operationele informatiesystemen voor de eerste- en tweedelijns zorg om medische zorg te documenteren. Deze systemen bieden de mogelijkheid om de traditionele papieren communicatie te vervangen door elektronische informatieuitwisseling tussen computers. In dit proefschrift noemen wij de laatst genoemde communicatie 'elektronische communicatie'.

Ondanks het feit dat in het algemeen wordt aangenomen dat elektronische communicatie voordelen heeft, is weinig hiervan bewezen. In Hoofdstuk 2 onderzochten we het effect van elektronische communicatie in de huisartsenpraktijk, beschreven in de peer-reviewed literatuur.

Wij onderzochten alle engelstalige publicaties die in MEDLINE geïndexeerd waren met de MESH term 'Computer Communication Networks' en daarbij tevens 'family practice' of 'primary health care' als MESH term of 'GP' of 'GPs' als tekst woord. In totaal werden 176 publikaties gevonden en hiervan voldeden 30 publikaties aan onze criteria. Van deze 30 publikaties beschreven slechts 5 publikaties bewezen effecten met objectieve gegevens en beschreven 3 publikaties aangetoonde effecten met subjectieve gegevens. Hoewel er een groot aantal mogelijke effecten zijn (snellere communicatie, verbeterde informatie in medische dossiers, verbeteringen in de zorg, etc) is alleen de snellere communicatie aangetoond in meer dan 2 onderzoeken.

In de Zwolse regio communiceren een aantal huisartsen elektronisch met openbare apothekers terwijl andere huisartsen in de regio middels papier communiceren. In Hoofdstuk 3 onderzochten we of elektronische communicatie tussen huisartsen en 
apothekers betere informatie geeft dan papieren communicatie over de gebruikte medicijnen van opgenomen patiënten in een ziekenhuis. Vijf huisartsen en een openbare apotheker communiceren elektronisch en werden vergeleken met vijf huisartsen en een openbare apotheker die middels papier communiceren. Op de opnamedag en 10 dagen na ontslag vroegen drie onafhankelijke data verzamelaars de patiënt, de huisarts en de openbare apotheker details over de gebruikte medicijnen van de patiënt.

We berekenden het aantal en de overeenkomst tussen gerapporteerde medicijnen die gecodeerd werden met de Anatomical Therapeutic Chemical (ATC) classificatie. In totaal werden 139 patiënten geïncludeerd op de opnamedag en 116 patiënten tien dagen na ontslag bij de elektronisch communicerende groep. Van de 275 medicamenten die werden gerapporteerd door de patiënt en/of de huisarts en/of de apotheker werden 134 (49\%) door alle drie partijen (patiënt, huisarts en apotheker) genoemd en 79 (29\%) werden niet door de patiënt genoemd.

Bij de middels papier communicerende groep werden 340 medicamenten gerapporteerd waarvan 107 (31\%) door alle drie partijen werden genoemd en 130 (38\%) niet door de patiënt werden genoemd.

Wij concluderen dat de elektronische communicatie tussen huisarts en de openbare apotheker resulteert in meer overeenstemming tussen huisarts en apotheker dan papieren communicatie met betrekking tot de gebruikte medicijnen van de patiënt. Elektronische communicatie voldoet echter niet om betrouwbare informatie te verkrijgen.

Patiënten die lijden aan kanker hebben eenduidig advies en informatie nodig over diverse aspecten van hun ziekte. Verschillende artsen, zoals huisartsen, radiologen en chirurgen, hebben te maken met patiënten met kanker. Er is echter weinig bekend over de snelheid van de communicatie, het type communicatie en de ervaren problemen door huisartsen en patiënten. In Hoofdstuk 4 onderzochten we de snelheid en het type communicatie tussen huisartsen, specialisten en patiënten met een mammacarcinoom. Daarnaast vroegen we de huisarts knelpunten in de communicatie met specialisten aan te geven met betrekking tot deze patiëntengroep. Totaal 246 huisartsen in de Zwolse regio werden gevraagd een enquête in te vullen gebaseerd op de laatste patiënt met een mammacarcinoom. Betrouwbaar ingevulde enquêtes werden ontvangen van $150(61 \%)$ huisartsen. De mediaan tussen de eerste verwijzing en de ontvangst van het bericht met de definitieve diagnose van de chirurg was vier weken. Na de eerste afspraak van de patiënt met de chirurg ontvingen huisartsen bij $24 \%$ van de patiënten brieven binnen 3 dagen, bij $31 \%$ van de patiënten van 3 tot 7 dagen en bij $16 \%$ van de patiënten na meer dan 2 weken. Na de eerste afspraak van de patiënt met de chirurg gaven $68(45 \%)$ van de 150 huisartsen aan dat de patiënt contact met hun had gezocht, slechts $30(20 \%)$ huisartsen had op dat moment een bericht van de chirurg. Huisartsen gaven aan dat de communicatie bij patiënten met een 
mammacarcinoom te langzaam (49\%) en niet frequent genoeg is $(25 \%) ; 25 \%$ van de huisartsen geven aan dat de taken tussen huisartsen en specialisten niet goed waren afgebakend. Onze conclusie is dat in de diagnostische fase van een mammacarcinoom de communicatie tussen huisartsen, specialisten en patiënten sterk varieert, te langzaam is en incompleet. Een effect van deze niet goed verlopende communicatie is dat de patiënt de boodschapper is van het slechte nieuws.

Het beschreven onderzoek in Hoofdstuk 4 was beperkt tot één regio in Nederland. Op basis van alleen dit onderzoek kan de inadequate communicatie tussen huisartsen en specialisten niet worden gegeneraliseerd voor geheel Nederland. In Hoofdstuk 5 onderzochten we of de problemen in de communicatie tussen huisartsen en specialisten ook bestonden in andere regio's in Nederland. We herhaalden het beschreven onderzoek in Hoofdstuk 4 in een andere regio: een verstedelijkte omgeving in West Nederland. Ook nu onderzochten we de snelheid en het type communicatie tussen huisartsen, specialisten en patiënten met een mammacarcinoom. Daarnaast vroegen we de huisarts knelpunten in de communicatie met specialisten aan te geven met betrekking tot deze patiëntengroep. Aan de artsen in een willekeurige steekproef van 235 van de 1200 huisartsen in een verstedelijkte omgeving in Nederland werd gevraagd een enquête in te vullen. Totaal werden $126(54 \%)$ betrouwbaar ingevulde enquêtes ontvangen van de 235 huisartsen. De gemiddelde tijd tussen de verwijzing van de patiënt naar de specialist en de ontvangst van de brief met de definitieve diagnose was 35 dagen. Nadat brieven van de chirurg waren ontvangen, zochten $70 \%$ van de huisartsen contact met de patiënt. In $30(23 \%)$ gevallen informeerde de patiënt als eerste de huisarts over de definitieve diagnose. De huisartsen gaven aan dat de communicatie van de specialist te langzaam (39\%) en niet frequent genoeg is $(29 \%)$.

Wij concluderen dat de communicatie in de diagnostische fase van mammacarcinoom tussen huisartsen, specialisten en patiënten vergelijkbaar is in beide regio's en voor verbetering vatbaar is.

De overblijvende vraag is of elektronische communicatie in staat is de communicatie tussen verschillende zorgverleners te verbeteren. In Hoofdstuk 6 beschrijven we een gerandomiseerd onderzoek. In dit onderzoek evalueerden we de effecten van elektronische communicatie op de snelheid van communicatie, de inhoud van communicatie en op de kwaliteit van leven in de behandeling van patiënten, die verdacht worden van een mammacarcinoom. In de voormeting werden 20 huisartsen praktijken ( 38 huisartsen) geïncludeerd. Na randomisatie werden 10 praktijken (17 huisartsen) geïncludeerd in de controlegroep en 10 praktijken werden geïncludeerd in de interventiegroep. Totaal 60 patiënten waren bereid om in de voormeting deel te nemen aan het onderzoek, 30 in de 
controlegroep en 55 in de interventiegroep. Psychosociale informatie over de patiënt was in $11 \%$ van de gevallen aanwezig in de verwijsbrief in de voormeting, in $14 \%$ van de controlegroep en in $39 \%$ van de interventiegroep. Voor aanwezige informatie over de gegeven voorlichting aan de patiënt waren de percentages $9 \%$, $7 \%$ en $69 \%$.

Psychosociale informatie over de patiënt was aanwezig in het eerste poliklinische bericht in $4 \%$ van de gevallen in de voormeting, in $7 \%$ van de controlegroep en in $15 \%$ van de interventiegroep. Voor aanwezige informatie over de gegeven voorlichting aan de patiënt waren de percentages $37 \%, 31 \%$ en $71 \%$. In ons onderzoek was er een significante invloed van elektronische communicatie op de tijd tussen het eerste consult bij de chirurg en de datum van de eerste brief van chirurg als de controlegroep en de interventiegroep met elkaar werden vergeleken. Wij concluderen dat elektronische communicatie toegevoegde waarde kan hebben ten aanzien van de implementatie van richtlijnen die betrekking hebben op de communicatie rondom patiënten met een specifieke diagnose. Andere effecten op communicatiegedrag tussen huisarts en chirurg en op de patiënt zelf werden door ons niet gemeten. 
GEARFETTING 

Yn Nederlân binne de measte minsken as pasjint yn de praktyk fan in húsdokter ynskreaun. Foar advys en behanneling nimt de pasjint kontakt op mei syn of har húsdokter. De húsdokter funksjonearret hjirby as in poartewachter yn de sûnenssoarch en dêrby ferwiist de húsdokter as it deroan leit de pasjint nei oare spesjalisten. Nei it stellen fan de diagnoaze en/of de behanneling fan de pasjint rapportearret de spesjalist werom nei de húsdokter. Optimale diagnostyk en behanneling easkje adekwate kommunikaasje tusken de húsdokter en de spesjalist.Kontinuiteit fan soarch is wakker offhinklik fan de kwaliteit en de frekwinsje fan de kommunikaasje tusken de oanbelangjende dokters yn dy soarch, Yn de kontinuiteit fan soarch is de húsdokter te beskôgjen as in 'ynformaasjemanager'. Om dizze funksje goed út te fieren is de húsdokter offhinklik fan ynformaasje fan oare wurkers yn de sûnenssoarch sa as bygelyks spesjalisten.

In protte ûndersiken hawwe sjen litten dat de tradisjonele skriftlike (papieren) kommunikaasje tusken húsdokters en spesjalisten te stadich, net kompleet, sûnder fertuten en ûnwier wêze kin. De tûkelteammen yn de papieren kommunikaasje tusken húsdokters en spesjalisten binne ûnnedich tiidferlies, net optimale of sels ferkearde behanneling, dûbele fêststellings yn de diagnostyk en ûnwissens of eangstme by de pasjint.

Nij opkommende technologyen resultearje yn tapaste ynformaasjesystemen foar de earste- en twaddegraads soarch om medyske noed te dokumentearjen. Dizze systemen meitsje it mooglik de tradisjonele papieren kommunikaasje te ferfangen troch elektroanyske útwikseling fan ynformaasje tusken kompjûters. Yn dit proefskrift neame wy de lêstneamde kommunikaasje 'elektroanyske kommunikaasje'.

Nettsjinsteande yn it algemien oannaam wurdt, dat elektroanyske kommmunikaasje foardielen opsmyt, is hjirfan net folle bewiisd. Yn Haadstik 2 ûndersochten wy it effekt fan elektroanyske kommunikaasje yn de praktyk fan húsdokters beskreaun yn de peer-reviewed literatuer. Wy ûndersochten alle ingelsktalige publikaasjes dy't yn MEDLINE mei de MESH-term 'Computer Communication Networks' en dêrby ek 'family practice' of 'primary health care' as MESH-term of 'GP' of 'GPs'as tekstwurd.Yn it totaal waarden 176 publikaasjes fûn en hjirfan foldienen 30 publikaasjes oan ús kriteria. Fan dizze 30 publikaasjes beskreaunen mar 5 publikaasjes bewiisde effekten mei objektive feiten en beskreaunen 3 publikaasjes oantoande effekten mei subjektive feiten. Hoewol't der in grut oantal mooglike effekten binne (fluggere kommunikaasje, ferbettere ynformaasje yn medyske dossiers, ferbetterings yn de soarch ensfh.), is allinnich de fluggere kommunikaasje yn mear as 2 ûndersiken te sjen.

Yn de Swolske regio kommunisearje guon húsdokters elektroanysk mei aptekers, wylst oare húsdokters yn de regio op papier kommunisearje. Yn haadstik 3 ûndersochten wy of elektroanyske kommunikaasje tusken húsdokters en aptekers 
bettere ynformaasje opsmyt as papieren kommunikaasje oer de troch yn in sikehûs opnommen pasjinten brakte medisinen. Fiif húsdokters en in iepenbiere apteker kommuniseatje elektroanysk en waarden ferlike mei frif húsdokters en in iepenbiere apteker dy't op papier kommunisearje. Op de deis fan it opnimmen en 10 dagen nei it ûntslach fregen trije ûnoffhinklike datagarders de pasjint, de húsdokter en de iepenbiere apteker details oer de troch de pasjint brûkte medisinen.

Wy berekkenen it oantal en de oerienkomst tusken rapportearre medisinen dy't kodearre waarden mei de Anatomical Therapeutic Chemical (ATC) klassifikaasje. Yn it totaal waarden 139 pasjinten ynkludearre op de deis fan it opnimmen en 116 pasjinten tsien dagen nei ûntslach by de elektroanyske kommunikaasjegroep. Fan de 275 medikaminten dy't troch de pasjint en/of de húsdokter en/of de apteker rapportearre waarden, waarden $134(49 \%)$ troch alle trije partijen (pasjint, húsdokter en apteker) neamd en 79 (29\%) waarden net troch de pasjint neamd. By de op papier kommunisearjende groep waarden 340 medikaminten rapportearre, wêffan $107(31 \%)$ troch alle trije partijen neamd waarden en $130(38 \%)$ warden net troch de pasjint neamd.

Wy konkludearje dat, wat de troch de pasjint brûkte medisinen oanbelanget de elektroanyske kommunikaasje tusken húdokter en en iepenbiere apteker resultearret yn mear oerienstimming tusken húsdokter en apteker as papieren kommunikaasje, Elektroanyske kommunikaasje foldocht lykwols net om betroubere ynformaasje te krijen.

Pasjinten dy't kanker hawwe, hawwe ferlet fan foar ien útlis fetbere rie en ynformaasje oer de ferskate aspekten fan hwat hja ûnder de lea hawwe.Ferskate dokters, lykas húsdokters, radiologen en sjirurgen hawwe te krijen mei pasjinten mei kanker. Der is lykwols net folle bekend oer de faasje en it type kommunikaasje en de troch de húsdokters en pasjinten ûnderfûne problemen. Yn Haadstik 4 ûndersochten wy de faasje en it type kommunikaasje tusken húsdokters, spesjalisten en pasjinten mei boarstkanker. Boppedat fregen wy de húsdokters oangeande dizze pasjintengroep swierrichheden yn de kommunikaasje mei spesjalisten oan te jaan. Yn it totaal 246 húsdokters yn de Swolske regio waarden frege in enkête yn te foljen basearre op de lêste pasjint mei boarstkanker. Sekuer ynfolle enkêtes waarden fan $150(61 \%)$ húsdokters ûntfong. De trochsnee tiid tusken de earste ferwizing en de ûntfangst fan it berjocht mei de definitive diagnoaze fan de sjirurch wie fjouwer wiken. Nei de earste ofspraak fan de pasjint mei de sjirurch krigen húsdokters by $24 \%$ fan de pasjinten brieven binnen 3 dagen, by $31 \%$ fan de pasjinten tusken 3 oant 7 dagen en by $16 \%$ fan de pasjinten nei mear as 2 wiken. Nei de earste ôfspraak fan de pasjint mei de sjirurch joegen 68 (45\%) fan de 145 húsdokters oan dat de pasjint kontakt mei harren socht hie, mar $30(20 \%)$ fan de húsdokters hienen op dat stuit in berjocht fan de sjirurch. Húsdokters joegen oan dat de kommunikaasje by pasjinten mei boarstkanker te 
stadich (49\%) en net frekwint genôch is (25\%):25\% fan de húsdokters jouwe oan dat de taken tusken húsdokters en spesjalisten net goed ôfbeakene wiene. Us konklúzje is dat yn de diagnostyske faze fan boarstkanker de kommunikaasje tusken húsdokters, spesjalisten en pasjinten sterk fariearret, te stadich is en ynkompleet. In effekt fan dizze net goed ferrinnende kommunikaasje is, dat de pasjint de boadskipper fan it minne nijs is.

It beskreaune ûndersyk yn Haadstik 4 wie beheind ta ien krite yn Nederlân. Op grûn fan inkeld dit ûndersyk kin de ûntarikkende kommunikaasje tusken húsdokters en spesjalisten net oer ien kaem helle wurde foar hiel Nederlân. Yn Haadstik 5 ûndersochten wy oft de swierrichheden yn de kommunikaasje tusken húsdokters en en spesjalisten ek yn oare regioanen yn Nederlân bestean. Wy dienen it yn Haadstik 4 beskreaune ûndersyk oer yn in oare regio: in ferstedske krite yn westlik Nederlân. Ek no ûndersochten wy de faasje en it type kommunikaasje tusken húsdokters, spesjalisten en pasjinten mei boarstkanker. Boppedat fregen wy de húsdokter oangeande dizze groep pasjinten swierrichheden yn de kommunikaasje mei spesjalisten oan te jaan oan. Samar in stekproef fan 235 fan de 1200 húsdokters waard frege in enkête yn te foljen op grûn fan ferstedske omkriten yn Nederlân. Yn it totaal waarden fan de 235 húsdokters 126 (54\%) sekuer ynfolle enkêtes ûntfong. De trochsnee tiid tusken de ferwizing fan de pasjint nei de spesjalist en de ûntfangst fan de brief mei de definitive diagnoaze wie 35 dagen. Neidat hja brieven fan de sjirurch krige hiene, sochten $70 \%$ fan de húsdokters kontakt mei de pasjint. Yn 30 (23\%) gefallen ynformearre de pasjint as earste de húsdokter oer de definitive diagnoaze. De húsdokters joegen oan dat de kommunikaasje fan de spesjalist te stadich (39\%) en net frekwint genôch is (29\%).

Wy konkludearje dat yn de diagnostyske faze fan boarstkanker de kommunikaasje tusken húsdokters, spesjalisten en pasjinten yn beide regioanente ferlykjen en foar ferbettering fetber is.

De oerbliuwende fraach is oft elektroanyske kommunikaasje by steat is de kommunikaasje tusken ûnderskate noeders te ferbetterjen. Yn Haadstik 6 beskriuwe wy in randomisearre ûndersyk. Yn dit ûndersyk evaluearren wy de effekten fan elektroanyske kommunikaasje op de faasje en de ynhâld fan de ynformaasjeútwikseling en op de libbenskwaliteit yn de behanneling fan pasjinten fan wa't tocht wurdt dat hja boarstkanker ûnder de lea hawwe.Yn de foarmjitting waarden 20 praktiken fan húsdokters (38 húsdokters) ynkludearre. Nei randomisaasje waarden 10 praktiken (17 húsdokters) ynkludearre yn de kontrôlegroep en 10 praktiken waarden ynkludearre yn de yntervinsjegroep. Yn it totaal 60 pasjinten wiene ree om yn de foarmjitting diel te nimmen oan it ûndersyk, 30 yn de kontrôlegroep en 55 yn de yntervinsjegroep. Psychososjale ynformaasje oer de pasjint wie oanwêzich yn $11 \%$ fan de gefallen yn de ferwiisbrief yn de foarmjitting, yn $14 \%$ fan de kontrôlegroep en yn $39 \%$ fan de yntervinsjegroep. Foar ynformaasje oer de oan de pasjint jûne foarljochting 
oanwêzich wiene de persintaazjes $37 \%, 31 \% \& 71 \%$. Yn ús ûndersyk wie der in sinjifikante ynfloed op de tiid tusken it earste kontakt by de sjirurch en de earste brief fan de sjirurch tusken de kontrôlegroep en de yntervinsjegroep.

Wy konkludearje dat elektroanyske kommunikaasje tafoege wearde hawwe kin foar it ta stân bringen fan rjochtlinen dy't slagge op de kommunikaasje rûnom guon kategoryen pasjinten Oare effekten op kommunikaasjegedrach fan de húsdokter en de sjirurch ûnderinoar en op de pasjint sels waarden troch ús net mjitten. 
CURriculum VitaE 

Wouter Jacob van der Kam was born in Heerenveen, The Netherlands, on April 30, 1956. After finishing Atheneum B in 1974, he studied medicine at the University of Groningen from which he graduated in 1981. From 1982 to 1983 he specialised in general-practice medicine. In 1983 he began his professional career as a military physician and from 1985 to 1992 he went into general practice in Kollum in Friesland.

In the ninety's he held several management positions within the health-care system: such as the regional 'cross' association Friesland Noord for home care, the nursing home De Weezenlanden and hospital De Weezenlanden.

Today he is assistant to the Executive Board of the Isala clinics in Zwolle, a general hospital with 1125 beds and 196 nursing-home beds, where he mainly focuses on medical affairs within the hospital.

In 1999 he started to work with the Department of Medical Informatics at the Erasmus University Rotterdam. In 1996 as well as in 1999 he received the Erasmus EMD award for the best scientific and most original contribution to the EMD conference in The Netherlands. 



\section{DANKWOORD}



Het doen van onderzoek en het voltooien van een proefschrift kan alleen met hulp van velen.

Maria, Marieke, Jaap-Jan en Christiaan zijn bovenal mijn maatjes op deze reis van jaren. Jullie stonden altijd voor me klaar en jullie accepteerden de druk in het gezin, die het onderzoek en dus ook je echtgenoot en vader met zich meebracht. Het was hartverwarmend, zonder jullie had ik niet kunnen promoveren. Graag wil ik jullie daarvoor bedanken.

Mijn ouders wil ik niet alleen danken voor de mogelijkheid dat ik heb mogen studeren, jullie gaven mij ook de steun en het vertrouwen om verder te gaan. Jullie altijd aanwezige belangstelling voor de voortgang van het onderzoek voelde goed.

Johan van der Lei is in het laatste jaar van het onderzoek voor mij van groot belang geweest. We hebben een groot aantal avonden bij je thuis lang gepraat en geschreven. Van jou heb ik geleerd zaken in de kern te beschouwen, alleen dat te doen wat echt noodzakelijk is. Graag wil ik je niet alleen bedanken voor je inspirerende wetenschappelijk bijdrage maar ook voor hoopvolle woorden als "promoveren is goedkoper dan een psychiater". Jij en je gezin wil ik daarnaast bedanken voor de gezellige gastvrijheid in Mijdrecht.

Betty Meyboom-de Jong heeft mijn wetenschappelijke ambities jarenlang gevolgd, we hebben samen voorzichtig vorm gegeven aan datgene wat ik echt wilde onderzoeken. Je bent goed geweest in het emotioneel begeleiden van de wat ongeduldige en gejaagde promovendus. Ook in de laatste fase van de afronding van het proefschrift, waarin feestdagen niet meer lijken te tellen, was je wetenschappelijke invloed daar waar nodig. Bedankt voor je geduld en bijdrage aan het proefschrift.

Jan van Bemmel gaf het onderzoek een zwaardere dimensie door een internationale engelstalige dimensie zonder pardon te eisen. Je gaf me tevens toegang tot de Erasmus Universiteit wat essentieel is geweest voor het verloop van het onderzoek. Veel respect heb ik voor je altijd aanwezige inzet om voorwaarden realiseren waaronder mensen kunnen werken en wetenschappelijk onderzoek kunnen voltooien. Veel dank voor dit misschien niet altijd zichtbare werk, voor mijn onderzoek is het essentieel geweest.

Peter Moorman, Peter Branger, Hans van der Wouden en Dick Tromp hebben elk vanuit hun achtergrond veel gedaan aan eerste hulp voor de promovendus, waarbij discussies werden uitgediept en niet uit de weg gegaan. Hun bijdragen hebben me verder geholpen en ik wil jullie daarvoor bedanken. Alex van 't Hooft wil ik danken voor zijn werkzaamheden als programmeur. Henk Bosveld voor zijn eeuwig optimistische inzet als methodoloog.

Onderzoek kan niet worden gedaan zonder een apparaat van begeleiding en ondersteuning. Een speciaal woord van dank voor Nettie Blankenstein en Willemjan Slort die in het kader van de stipendiumregeling van het Nederlands 
Huisartsen Genootschap mij uit een vroege onderzoekers-dip haalden en mijn vraagstelling structureerden. Bijzonder was later ook de inzet van de studenten Marjan Koppejan-Mulder, Annemarie Schot, Debbie Geijsen, Ellen Nijland, Ageeth Grotenhuis, Cora Mout en Neline Kramer. Zij combineerden eigen vraagstellingen met deeltaken in de voorbereiding, uitvoering of analyse van het onderzoek. Belangrijk was ook in het laatste jaar de enthousiaste medewerking van Anne Mieke Versteeg vanuit Diagram b.v.

Onderzoek naar communicatie betekent ook medewerking van verschillende communicerende partijen. Allereerst is een woord van dank verschuldigd aan alle patiënten die in een zeer onzekere periode in hun leven mee wilden werken aan de diverse onderdelen van het promotie onderzoek. Daarnaast wil ik hun huisartsen, apothekers en chirurgen bedanken, die niet alleen bereid waren tijd en energie in het onderzoek te steken, maar ook bereid waren om hun communicatiegedrag en de gevolgen van dit gedrag te evalueren. In het bijzonder wil ik Piet Spoelstra, Jos Lemmens en Wim Segers bedanken voor hun voortrekkende en toetsende rol als huisarts in het onderzoek.

Alles zou nog niet goed zijn verlopen zonder de nimmer aflatende steun van de Isala klinieken. Niet alleen werd mijn werk als onderzoeker gestimuleerd door de Raad van Bestuur, ook werd intensief samengewerkt met het secretariaat van de Raad van Bestuur. Met name Irmgard Wilke en later Loes Wielandt hebben daar bijgesprongen waar de continuiteit van het onderzoek of de rapportage van het onderzoek gevaar liep.

Vanuit de ziekenhuisorganisatie zijn voorts de afdelingen opname en planning, de chirurgische verpleegafdelingen en chirurgische poliklinieken van belang geweest op beide ziekenhuis locaties.

Belangrijk ondersteunend waren de dienst automatisering en de medische bibliotheek. Deze diensten legden elk vanuit hun eigen invalshoek een essentiële basis voor het onderzoek. De altijd loyale medewerking was plezierig en stimulerend.

In de laatste spannende weken was de inzet van Thea Schenk met haar deskundigheid op het gebied van de engelse taal en lay out nodig om mij en dit proefschrift naar de eindstreep te brengen. Geert Bosma en Karina van der LindenBreedveld wil ik hartelijk bedanken voor hun hulp in het Fries en Engels.

Tot slot een woord van dank aan alle vrienden, familie, collega's en medische stafleden die mij voortdurend gestimuleerd hebben om hoe dan ook door te gaan. 


\section{PARTICIPATING DISCIPLINES IN ONE OR MORE STUDIES}

Participating general practitioners:

T. Annema, E.J. van Apeldoorn, A.A.M. Appel, K.H.G. Bakker, F.L.M. Bank, P.E. Beetz, J.L. ten Berg, A.H. Bergsma, J.C. Boddeus, J.G.J. de Boer, A.G.R. Broere, H.P. Boerema, F.J.W. Drion, H. van Es, J.G. van der Flier, H.C. Fluyt, D.F. Gelderman, P.A. Gille, E.H.D. de Groot, A.J.M. Groot, C. Hartman, G.C.M. Heydra, R. van der Hoef, G. Hoogvliet, W.M. van den Hurk, P. van der Hurk, A. Hutter, T.J. Jansen, E.G.A. de Jong, R.J. Kars, J. Kiewiet, G. Klazama, D.M. van Leeuwen, J.H.M.P. Lemmens, M.F. Luiting, C. Meeder, C. Meyer, J.B.T. Meijer, D.J. Meulman, F.Moerman, A. Mulder, A. Nieuwenhuis-Veldhuis, P.K. Pel, D. Prins, J. Posthouwer, J.M. van de Riet, F.N. Ridderbos, P.M. Roseboom, S. Rijneke, G. Scheurs, M. Schouwink, O. Schwantje, W.G.C. Segers, R. Sikkema, H.A. Speijers, P. Spoelstra, R.L. Verhey, S. Verhoeven, J.H.F. de Vries, R. de Wilde, D.H. Zwanenburg, J. Zwanenburg, S. Zwart.

Participating pharmacist:

IJsselmuiden apotheek, Apotheek Heerde.

Participating surgeons:

Dr. J.E. de Vries, Dr. M. Lopes Cardozo, Dr. E.G.J.M. Pierik. 


